THE UNIVERSITY OF MINNESOTA

GRADUATE SCHOOL

\title{
Report
}

of

Committee on Examination

This is to certify that we the

undersigned, as a committee of the Graduate

School, have given Walter Iven Lillie

final oral examination for the degree of

Master of scionce in ophthalmology.

We recommend that the degree of

Westar of Sciance in Ophtralmology

be conferred upon the candidate.

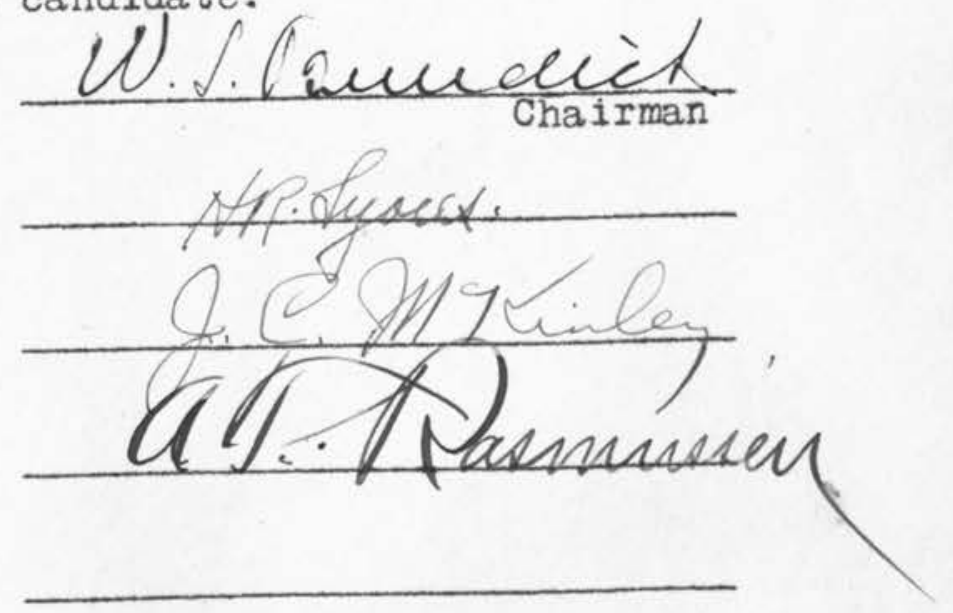

Date Dee2-1922 
Graduate Sohool, University of Winnesota.

Dete: November 1.1, 1922

This is to certify that Walter Ivan Iillie, a candidate for the degroe of Waster of Science in Ophthalmology, has passed the final written examination for the major in the Department of Ophthalmology.

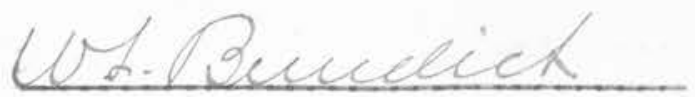

For the Major Department.

Graduate School, University of Minnesota.

Date: November 1I, 1922.

This is to certify that Walter Ivan Lillie, a candidate for the degree of Naster of Science in ophthalmology, has completed the requirements for the minor in the Depariment of Neurolesto?

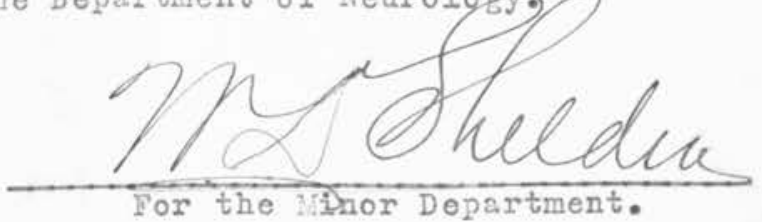


REPORT

of

Combttee on Thesia

The underaifned, soting as a Cormattoe of the

Gradunbe Sohool, hsve rond the sooompanying thesis

autultted by Taltor Ivan L121ㅇ for the degree of

Hater of Solenoe in Ophthelnolosy. Thoy approve

It an s thesis noeting the requirotadnts of the

Gradusto Solool of the Univoralty of Minnosots,

snd reoomond that it be aoooptod in partial enz-

Iflument of the requirenents for the degreo of

Master of Soforroo in Ophthalmolosy.

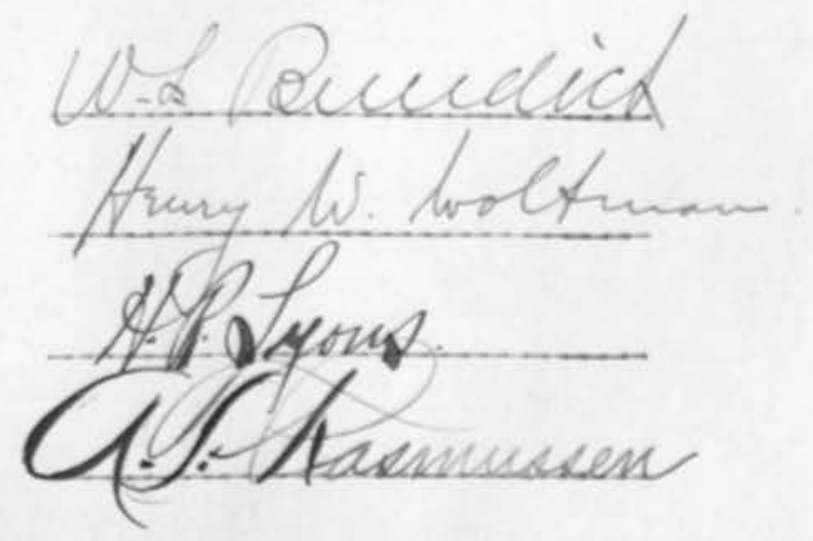

$10-2659$ 
THISS IS

OCULAR PHEHOIMAIA PRODUCED BY IIIRACRUIII LISIOIS

IUVOLVIUG THE OPTIC TRACMS NEAR THE CHIASM.

Walter Iran ItIlie, M.D.

Submitted to the faculty of the Graduste Sohool of the University of Minnesota in partial fulfilluent of the

requirements for the degree of Kastor of Solence in

OphthaImology.

ootober, 1922. 
$M O M$
$2 L 6283$

The study of the following cases of intracranial lesions affecting the chism has been carried on to ascertuin whether some ophthalmologic method of examination could be found to enable the ophthalmologist to determine more definitely the origin or position of the lesion affecting the chiasm.

31

Anatomy of the Chiasm (Traquajir ). "In many, even up-to-date, textbooks, whether of anatomy or of ophthalmology, the ohiasm is said to lie upon the pptic groove of the sphenoid, all further details being permitted to remain in pbourity. This description is not based on actual observation and is completely imaginary. Only the anterior half of the chiasma could lie on the narrow optic froove; the posterior part would lie over the olivary eminence and the anterior edge of the sella turcica. The angle between the two optic nerves would require to be practioally equal to two right angles. The infundibulun would pass vertically domnards or even dovnwards and backwards to the pituitary body, leaving a Fide angle between its anterior surface and the inferior surface of the chiasma. Such conditions very seldom occur.

"The anatomical relations of these parts have been studied by Lamrence,

fawoett, Zander, Hirsch, Wallis, and Cope, and rost of the essential points may be fegarded as established. The optio groove wus found by Zander in only 34 per cent f skulls. Behind this lies the olivary eminence, which varies greatly in size and is very often poorly developed. The sphenoidal cells, when well developed, extend peneath the optic groove, olivary eminence, and sella turoics. The dorsum sellae, frowned by the posterior margin of the latter is more variable and corresponds to the posterior margin of the olivary eminence. The diaphragma sellae is a fold of fura mater which roofs in the solla. It is attaohed in front to the posterior pargin of the olivary eminence, a band on each side passing to the lower edge of the optic foramen, and behind to, or immediately below, the crest of the dorsun Sllae.

"In or often slightly behind, the centre of the diaphragma is an opering hrough the posterior part of which the infundibulum passes. This opening, or 

for the infundibulum. It is filled in by a thin transparent mombane, through whioh the hypophysis is visible, and whioh may form almost the whole roof of the sella, the diaphragma itself being reduoed to a mere rim. In suoh oases there would be practioally no obstruction to the easy upvard growth of an hypophyseal tumor. Thus the area under consideration extends from the limbus sphenoidalis in eront to the dorsum sellae behind and consiats anteriorly of a thin bony wall of variable extent covering the sphenoidal cells and gesteriorly of a membranous layer of varying thicleness covering the pituitary body. Above these structures Iie the optic nerves and chisans. While the plane of the area desoribed is approxf imately horizontal, or sloping a little dormvards posteriorly, thst of the optic nerves and chiasma inclines slightly upwsrds behind, so that the back of the ohiasma lies at a somewhat higher level than the optio foramina, and the spaoe between the chiasma and the subjacent structure incresses from before backwars. The intracranial part of the optio nerve varies greatly in length from $1 \mathrm{~mm}$. to as much as $21 \mathrm{~mm}$, areraging $13 \mathrm{~mm}$. (2ander). The position and relation of the ohiasma obviously depend to an important degree upon this factor, as the shorter the nerves are the more relatively anterior vill be the ohiama and vioe versa. The angle between the optic nerves is usually more or less soute, quite unlike the very obtuse angle becomes wide and the chissma therefore occupies a Lomrard position. In suoh osses, whioh are not common, s vell developed olivary eminence is benesth and possibly in contact with the anterior border of the ohiasma. In eleven subjects Walis observed one case in whioh more than one-hale of the ohisama lay upon the optio sulcus and the olivary ominonoe. Judging by the finaings of others, the proportion of suoh osses must be much less than one to eleven.

"If the ohiasma with the apex of the third ventricle be left in situ, after remoral of the rest of the brain and vieved from above, a wedge-shsped portion of the diaphragma sellae, eztonding backrards to the extent of a third or a 
half, or even more of its anterioposterior diameter, will usually be aeen in the angle between the optic nerves and frequently also a portion of the foramen diaphragmatis. Thus the ohiasma lies rell belind and above the usually desoribed position. Its posterior edge projects behind the level of the dorsum sellae to an averege of $1.58 \mathrm{~mm}$. (Zander) and is very rarely found in front of this point. A large subarachnoid space lies beneath the chiasna, and the vertical distance between its lover surface and the diaphragma seliae is as much as 5 ma. to $10 \mathrm{~mm}$, according to different observers.

"The writers mentioned pay scant attention to the position of the infundiff bulum. The structure, as is well knom, resembles a much elongsted funnel, being thin at its termination and considerably thicicer where it leaves the third ventriole. At this point it lies behind the level of the dorsum sellae, over whioh it passes in a forvard and domward direction. Immediately beyond its commencement it is in contact with the centre of the lower and posterior suriace of the chiama. As it arohes over the dorsun sellae, its direction is almost parallel to the plane of the chiasma. In front of the dorsum sellae it is direoted nore domwards, loaving the chiasma at a very acute angle, snd passes to the posterior edge of the foramen diaphragmatis keeping olose to the dura covering the dorsur sellae. "It is important to remember that it is the infundibulum and not the hypophysis which is in immediate contact with the chiasma. The pia mater stretche across between the optio nerves like an apron and is olosely adherent to their Lover surfaces. At the sides it is attached to the carotid arteries and behind to the anterior border of the chiasma and to the infundibulum which it olosely surrounds. Deliadte conneations pass betveen the pia and the durs over the roof of the osvernous sinus and over the dorsum sellae. In front of the infundibulum and anterior border of the chiasma, over the diaphragma sellae and the sphenoid, there is a free space, apparently without connecting filaments.

"The relation of the chiasma to the circle of Willis is of sone importanod 3n that the anterior communiosting artery lies across the two optio nerves. When 
the olisams is forced uprovas by a tumor the optio nerves are compressed between the vassele, usually the beginning of the anterior oerebrals, and the turnor. This point is referred to by ththoff and others, especially by Firsoh. Barties states that if the constriotion is alight and slowly developed, direot damage to the nerve need not restrit.

"Nnother pathological anatomionl festure is the indentation of the optio Herve at the entrance to the optio formen when the ohinama is pressed upwtus. This conditzon sis refecred to by walker and Cushing and by Uhthopf who, homever, Lailed to ilnd eny true constriction of the nerve at this point."

The oases reported in this study have been divided on the basis of the oritin of the lesion into six groups in order to show the striking similarity in the ocular phononens, together with the changes in the sella turoica as show iy the roenteonogram. The six groups are:

Group 1. Pituitary tumors without Elandular disturbances.

Group 2. Pituitary turors with acromegaly.

Group 3. Pituitsry tumors with aisbotes insipias.

Group 1. Introaranial tumors, not of pituitary orifin, affecting the chis asm.

Group 5. Waso-PhaxyngeaI tunors affectimg the chissm.

Group 6. Luetio basal moningitis sefeoting the chissm.

Pituitary Tumors.

So much has been writhed by individusls or in colleotive roports conoerning the oculsx phenomena resulting from tumors of tie pituitary body thet it 5.s useless to try to give a detalled report of this literature. In over four hundred references from the literature I have found that haxdly 5 per cent are certiliod cases but generally a suspected tumor is reported. me outstanding works on this subjeot oan be obtained in two well lenown volumes: Cushing, nme Pituitary Body and its disorders," published in 1912, and Filorand und saengor, 
"Die neurologie des Augea", volume vi, published in 1915. The first book gives 256 references and the latter gives 742 referenoes from the literature. These two rolumes will suffice to acquaint any one with the amount of careful study alresdy given to this subject. Since 1915 a few authors stand out far supreme to the mass of contributors on the subject and one only has to mention Josefson, Ronne,

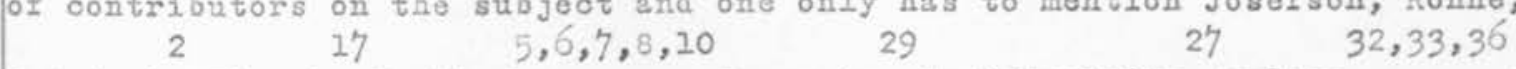
Bogatsoh, Hirsoh, Cushing, Traquair, de Schveinitz, Halker, and 24

Peter, to see the amount of oareful study that has been done conoerning the peri20 metric defects produced by ohissmal lesions. Of the foreisn authors Joselson, Ronne, Hirsch, and Traquair, have contributed much to our knomledge oonoerning the fleld changes in ohiasmal lesions. One only has to consider the great contributioz ooncerning perimetry by Ronne in the early field ohanges in flauooma to realize 31

hoir careful a vorker he has been. Traquair also has contributed considerable work on the scotomatous type of field changes as has de Schreinitz in this country. 34 36

Walker, under the careful guidance of Harvey Cushing, has contributed lergely to studies of perimetry in this country. Although we view some phases of his teohnique with reservation one cannot but admit that he has placed orreful perimetrio observations in the foreground. The greatest oompliment one can extend to Walker 11

in regard to perimetric work has been expressed by Cushing. "The difference is as great as that before a ohild's sketoh and an architeot's draving to sosie." In the series of forty-six oases of pituitary tumor reported in this study twenty-seven did not slow any glandular disturbances, seventeen cases were definitely acromegalic, and diabetis insipidus was found in only two cases.

Report of cases

$\begin{array}{ll}\text { Group } & 1 . \\ \text { Group } & 2 . \\ \text { Group } 3 .\end{array}$

Visual fields of Groups I and 2 .

Visual fields of Group 3 . 
Group 1

Chart I

Pituitary Tumors Without Glandular Disturbances

Pituitary

\begin{tabular}{|c|c|c|c|c|c|c|c|c|c|c|c|c|c|}
\hline$\sum_{0}^{\infty}$ & 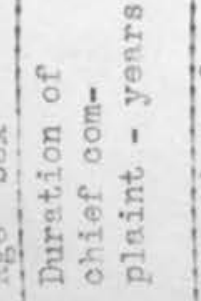 & 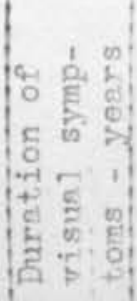 & 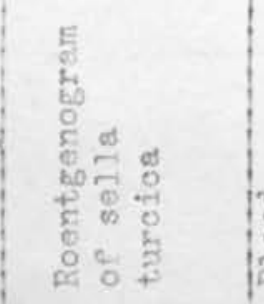 & 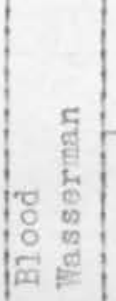 & 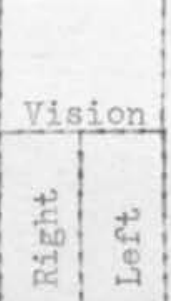 & 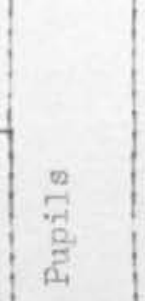 & 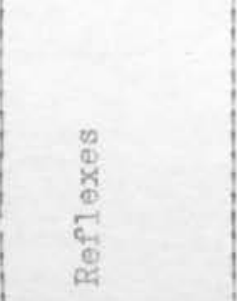 & 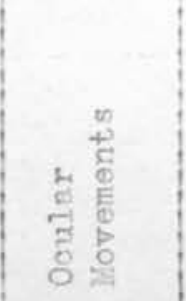 & 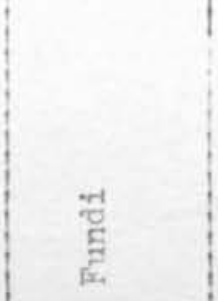 & 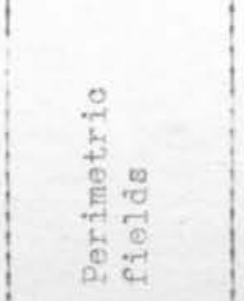 & 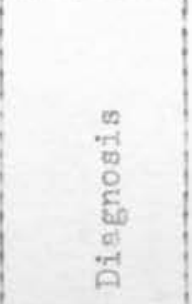 & $\begin{array}{l}\overrightarrow{2} \\
\text { to } \\
\text { है } \\
\text { के }\end{array}$ & $\frac{\text { कै }}{\text { के }}$ \\
\hline A15560 & $\begin{array}{l}\text { fimenor- } \\
\text { lphoes } \\
\text { for } 12 \\
\text { fenrs } \\
\text { convul- } \\
\text { sions }\end{array}$ & 7 & $\begin{array}{l}\text { miarged } \\
\text { rith erosiont } \\
\text { of posterior } \\
\text { linoids }\end{array}$ & & inis/10 & $\begin{array}{l}\text { fight } \\
\text { targer } \\
\text { than } \\
\text { heft } \\
\text { t }\end{array}$ & $\begin{array}{l}\text { Right con- } \\
\text { sensunl and: } \\
\text { hcoommoda- } \\
\text { tion Left } \\
\text { direct and } \\
\text { hocommoda- } \\
\text { tion }\end{array}$ & TormaI & $\begin{array}{l}\text { Right } \mathrm{sec}- \\
\text { ondary } \\
\text { optic at- } \\
\text { fophy Left } \\
\text { how grade } \\
\text { pptic neu- } \\
\text { fitis }\end{array}$ & $\begin{array}{l}\text { heft tempo- } \\
\text { ral hemia- } \\
\text { hopsia }\end{array}$ & hesion & $\begin{array}{l}\text { PI/AT } \\
\text { Pituitary } \\
\text { tumor }\end{array}$ & $\begin{array}{l}\text { Pathological re- } \\
\text { port-malignant } \\
\text { fumor mass exten- } \\
\text { bed into the } \\
\text { frontel lobe and } \\
\text { back along the } \\
\text { brein stem. }\end{array}$ \\
\hline A91684 & $\begin{array}{l}\text { Failing } \\
\text { strision } \\
\text { ponval- } \\
\text { sions } \\
\text { is yenrs }\end{array}$ & s & $\begin{array}{l}\text { Enlarged } 4 \\
\text { with ero- } \\
\text { gion of pos- } \\
\text { terior ali- } \\
\text { noids }\end{array}$ & tive & $6 / 12,111$ & $\begin{array}{l}\text { Left } \\
\text { harger } \\
\text { than } \\
\text { right }\end{array}$ & Normal & $\begin{array}{l}\text { Tealcness } \\
\text { lof left } \\
\text { internal } \\
\text { rectus }\end{array}$ & $\begin{array}{l}\text { Pallor of } \\
\text { poth nervel } \\
\text { heads }\end{array}$ & $\begin{array}{l}\text { Temporal } \\
\text { highianopsiat eyo }\end{array}$ & Pituitary & $\begin{array}{l}\text { Craniotomy } \\
5 / 22 / 21 \\
\text { Pituitery } \\
\text { tumor }\end{array}$ & $\begin{array}{l}\text { lecropsy } 3 / 24 / 21 \\
\text { Hoderate extra- } \\
\text { lural hemorrhage. } \\
\text { foderate nephritis } \\
\text { Mrteriosclerosis }\end{array}$ \\
\hline A201188 & $\begin{array}{l}\text { Failing } \\
\text { oyision }\end{array}$ & 2 & $\begin{array}{l}\text { Whiarged } 4 \\
\text { pith rough- } \\
\text { pning of } \\
\text { posterior } \\
\text { rall }\end{array}$ & $\begin{array}{l}\text { Mega-p } \\
\text { tive }\end{array}$ & $6 / 12 d \cdot$. & - Equal & flormal & Normal & $\begin{array}{l}\text { Pallor of } \\
\text { herve } \\
\text { heads }\end{array}$ & Bitomporal & $\begin{array}{l}\text { Pituitary } \\
\text { ftumor }\end{array}$ & $\begin{array}{l}8 / 22 / 17 \\
\text { Pituitery } \\
\text { tumor }\end{array}$ & $\begin{array}{l}\text { Fields improvod } \\
\text { ponsidersbly }\end{array}$ \\
\hline $\begin{array}{l}1207279 M \\
9 / 7 / 17 \text { i }\end{array}$ & $\begin{array}{l}\text { Failing } \\
\text { 3vision }\end{array}$ & $\overline{2}$ & formal & $\begin{array}{l}\text { Nega-1 } \\
\text { ive }\end{array}$ & C.f. $6 / 15$ & 5ैounl & Iformal & Normal & $\begin{array}{l}\text { Simple op- } \\
\text { tic atro- } \\
\text { phy both } \\
\text { pyes }\end{array}$ & hitemporal & $\begin{array}{l}\text { Pituitary } \\
\text { tumor }\end{array}$ & $\begin{array}{l}10 / 10 / 17 \\
\text { Pituitary } \\
\text { tumor }\end{array}$ & \\
\hline $1 / 12 / 18$ & & & & & $1.0 .1 / 60$ & ofqual & fiormal & Norma 1 & $\begin{array}{l}\text { Bimple op- } \\
\text { tic stro- } \\
\text { phy both } \\
\text { eyes }\end{array}$ & $\begin{array}{l}\text { Some im- } \\
\text { forovement } \\
\text { in left } \\
\text { field }\end{array}$ & & & \\
\hline
\end{tabular}


Group 1 continued

\begin{tabular}{|c|c|c|c|c|c|c|c|c|c|c|c|c|c|}
\hline $\begin{array}{l}207279 \\
4 / 30 / 18\end{array}$ & & & & F.f. & $17 / 6$ & Equal & {$\left[\begin{array}{l}\text { light } \\
\text { slort } \\
\text { Laft } \\
\text { normal }\end{array}\right.$} & Tormal & $\begin{array}{l}\text { Sinmle optial } \\
\text { ntrophy not } \\
\text { so morked in } \\
\text { left }\end{array}$ & $\begin{array}{l}\text { Some improve- } \\
\text { ment in left } \\
\text { field }\end{array}$ & & & \\
\hline $12 / 31 / 18$ & & & & & 276 & Equal & \begin{tabular}{l|} 
slow \\
Left \\
normal
\end{tabular} & $\begin{array}{l}\text { Normal: } \\
\vdots \\
\end{array}$ & $\begin{array}{l}\text { Simple opticl } \\
\text { atrophy not } \\
\text { so marked in } \\
\text { laft }\end{array}$ & $\begin{array}{l}\text { Some improve- } \\
\text { ment in left } \\
\text { field }\end{array}$ & & & \\
\hline $6 / 5 / 20$ & & & & & M.O. & Equal! & $\begin{array}{l}\text { Right } \\
\text { slowr } \\
\text { Left } \\
\text { nornal }\end{array}$ & Norme1: & $\begin{array}{l}\text { Simple opticl } \\
\text { ntrophy not } \\
\text { so marked in } \\
\text { left }\end{array}$ & $\begin{array}{l}\text { Bitemporel } \\
\text { heminnopsia }\end{array}$ & & & \\
\hline $\begin{array}{rl}234782 & F \\
3 & 3 \\
\end{array}$ & $\begin{array}{l}\text { Fordache, } \\
\text { 38Blind- } \\
\text { hess }\end{array}$ & prat sella & $\begin{array}{l}\text { Nega-p } \\
\text { tive }\end{array}$ & $5 / 60$ & C.f: & Equal & $\$ 10 \mathrm{~W}$ & Normal. & Normal & $\begin{array}{l}\text { Bitemporal } \\
\text { hemionopsia }\end{array}$ & $\begin{array}{l}\text { Pituitary: } \\
\text { tumor }\end{array}$ & $\begin{array}{l}\text { Pitui, tary } \\
\text { cyst } \\
8 / 10 / 18\end{array}$ & $\begin{array}{l}\text { Patient died in } \\
\text { summer of } 1919 .\end{array}$ \\
\hline $\begin{array}{l}1236675 \\
6 / 27 / 18 \\
\end{array}$ & $\begin{array}{l}\text { Head- } \\
\text { 29poses } 4 \\
\text { vears } \\
\text { pailing } \\
\text { vision }\end{array}$ & $\begin{array}{l}\text { pinlarged } \\
\text { prith thin- } \\
\text { ming of } \\
\text { bese and } \\
\text { posterior } \\
\text { clinoids }\end{array}$ & $\begin{array}{l}\text { Negra-5 } \\
\text { tive }\end{array}$ & 5 & $8 / 2 d$ & Fqua! & Norma! & Normal & Normal & $\begin{array}{l}\text { Bitemporal } \\
\text { heminnopsia } \\
\text { for colors }\end{array}$ & $\begin{array}{l}\text { Pituitary! } \\
\text { tumor }\end{array}$ & & \\
\hline $11 / 3 / 19$ & & & & & 6720 & Equal & Normel: & Normal & $\begin{array}{l}\text { Pallor of } \\
\text { both dises }\end{array}$ & $\begin{array}{l}\text { Partiol bi- } \\
\text { temporal } \\
\text { hemianopsia }\end{array}$ & & $\begin{array}{l}12 / 6 / 19 \\
\text { Pituitary } \\
\text { tumor }\end{array}$ & $\begin{array}{l}\text { Pathological } \\
\text { report - glioma }\end{array}$ \\
\hline $8 / 24 / 21$ & & 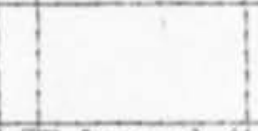 & & & $6 / 1$ & Equal! & Norma? & Normal! & $\begin{array}{l}\text { Simple optic } \\
\text { atrophy both } \\
\text { ayes }\end{array}$ & $\begin{array}{l}\text { Partial bi- } \\
\text { tempornl } \\
\text { hemianopsia }\end{array}$ & & & \\
\hline 1248126 & $\begin{array}{l}\text { Bifind- } \\
\text { 26hess }\end{array}$ & $\begin{array}{l}\text { 3inlarged } 4 \\
\text { prith de- } \\
\text { struction } \\
\text { pf poster- } \\
\text { for oli- } \\
\text { poids }\end{array}$ & $\left\{\begin{array}{l}\text { Nege- } \\
\text { tive }\end{array}\right.$ & L.P. & 17.0. & Equal, & Normal! & Normal & $\begin{array}{l}\text { S1ight pal- } \\
\text { lor of nerve } \\
\text { heads }\end{array}$ & $\begin{array}{l}\text { Unable to } \\
\text { obtain }\end{array}$ & $\begin{array}{l}\text { Pituitary } \\
\text { tumor }\end{array}$ & $10 / 20 / 18$ & $\begin{array}{l}\text { Necropsy } 10 / 30 / 19 \\
\text { Epithelial growth } \\
\text { from anterior lobe } \\
\text { pf pituitery } \\
\end{array}$ \\
\hline $\begin{array}{l}\text { A250408 } \\
11 / 13 / 18 / 4\end{array}$ & $\begin{array}{l}\text { Faling } \\
\text { flyision }\end{array}$ & $\begin{array}{l}\text { 3arge cal-1 } \\
\text { pified pi-1 } \\
\text { heal gland } \\
\text { pella nor- } \\
\text { mal }\end{array}$ & $\begin{array}{l}\text { Hegn-p } \\
\text { tive }\end{array}$ & $5 / 30$ & $6 / 5$ & Wqual & Norme 1 & Normel & $\begin{array}{l}\text { Slieht pal- } \\
\text { lor nervo } \\
\text { hands }\end{array}$ & $\begin{array}{l}\text { Bitemporal } \\
\text { hemianopsia }\end{array}$ & $\begin{array}{l}\text { Pansinu- } \\
\text { sitis }\end{array}$ & $\begin{array}{l}11718 / 18 \\
\text { Exenter- } \\
\text { ation of } \\
\text { sinuses }\end{array}$ & $\begin{array}{l}\text { iddle meatus and } \\
\text { pthmoid labyrinth } \\
\text { fillod with pus }\end{array}$ \\
\hline $11 / 29 / 18$ & , & & & 712 & $6 / 10$ & Equal & Normal & Normal & $\begin{array}{l}\text { Slight pal- } \\
\text { lor nerve } \\
\text { heads }\end{array}$ & $\begin{array}{l}\text { Yinrked im- } \\
\text { provement in } \\
\text { temporal } \\
\text { fields }\end{array}$ & & & $\frac{1}{1}$ \\
\hline
\end{tabular}




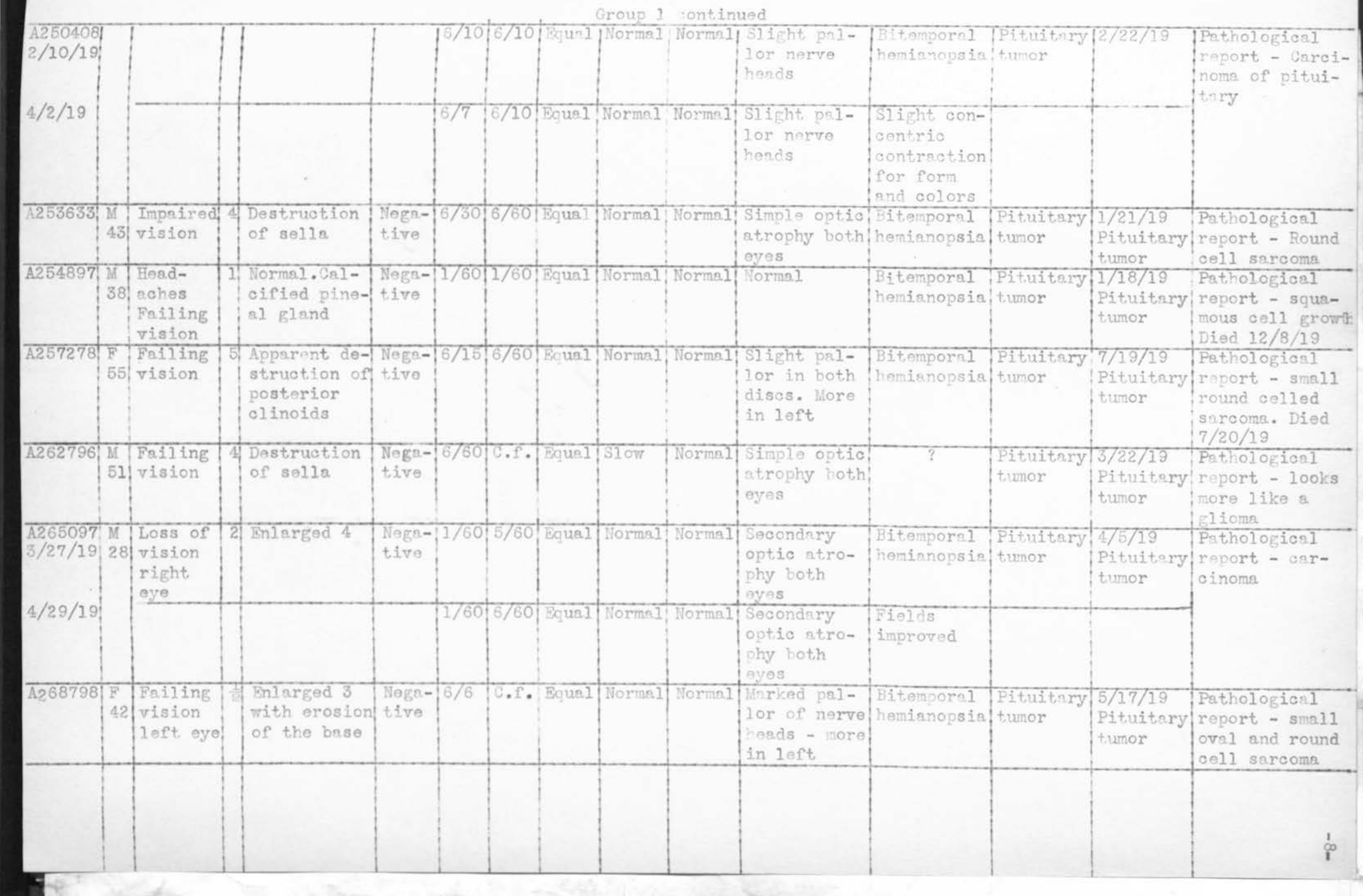


Group 1 continued

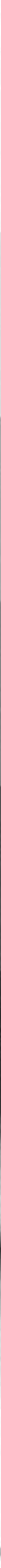




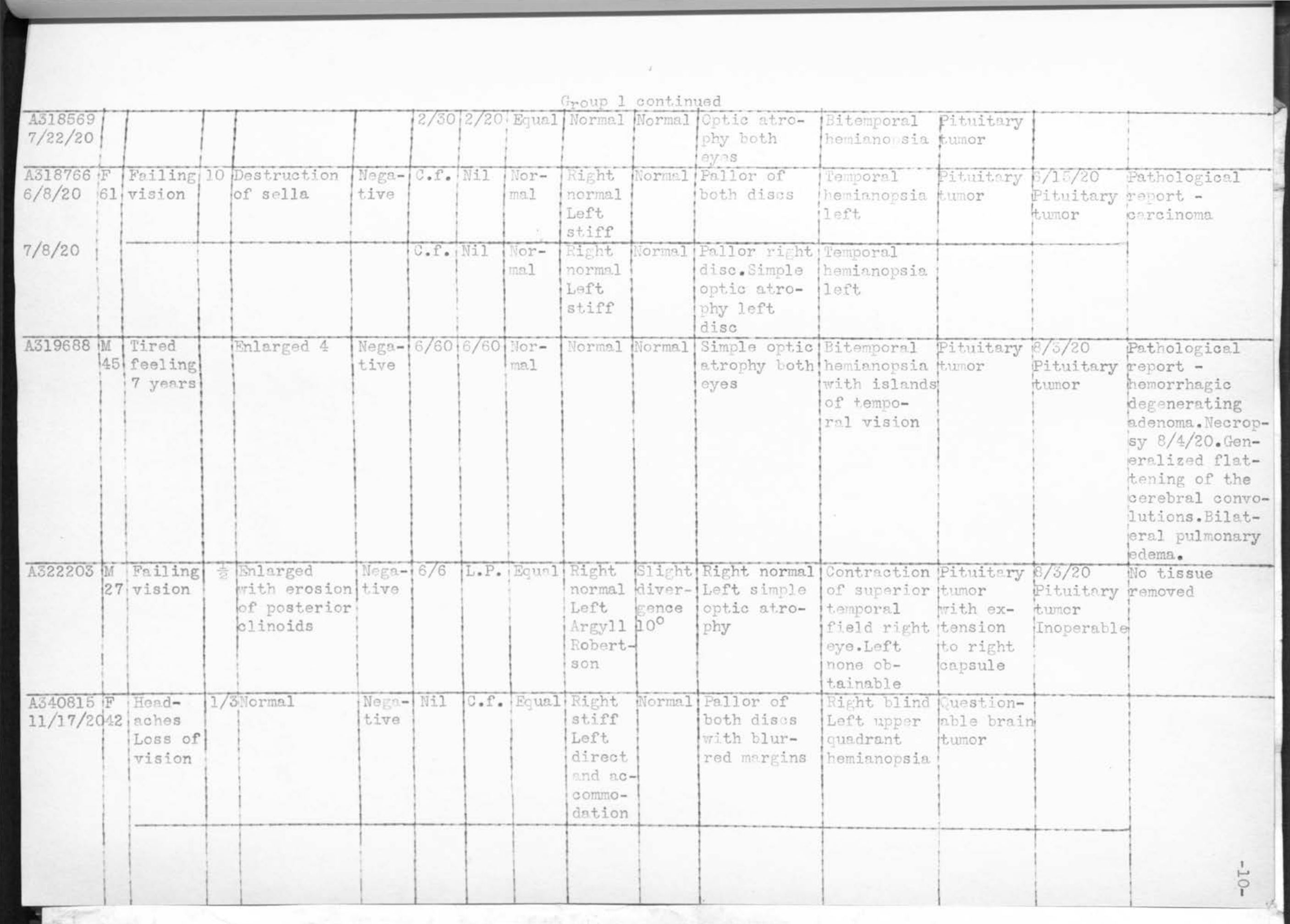


Grous 1 continuse

\begin{tabular}{|c|c|c|c|c|c|c|c|c|c|c|c|c|c|c|c|}
\hline $\begin{array}{l}4340815 \\
1 / 7 / 21\end{array}$ & & & & & & Til & $5 / 60$ & Equa.? & $\begin{array}{l}\text { Right } \\
\text { stiff } \\
\text { Left } \\
\text { diroct } \\
\text { end ac- } \\
\text { commo- } \\
\text { dation }\end{array}$ & forme? & $\begin{array}{l}\text { optio gtro- } \\
\text { phy right } \\
\text { Ieft cholod } \\
\text { disc one } \\
\text { diopter }\end{array}$ & & & & \\
\hline $22 / 21$ & & & & & & Nil & $5 / 60$ & Equel & \begin{tabular}{|l|} 
ilift \\
stiff \\
Left \\
direct \\
and ac- \\
commo- \\
dation
\end{tabular} & Normal & $\begin{array}{l}\text { Optic ntro- } \\
\text { phy right } \\
\text { Left choked } \\
\text { disc one } \\
\text { diopter }\end{array}$ & - & & $\begin{array}{l}\text { A/28/2I } \\
\text { Fight } \\
\text { subtempo- } \\
\text { ral decom } \\
\text { pression }\end{array}$ & $\begin{array}{l}\text { Wecropsy } 5 / 4 / 21 \\
\text { hemangioma of } \\
\text { the Pituitary } \\
\text { Dilated sps.ces } \\
\text { filled with } \\
\text { blood. Narked in } \\
\text { crease of baso- } \\
\text { philic cells. }\end{array}$ \\
\hline 54926 & \begin{tabular}{|l|}
$F$ \\
38
\end{tabular} & $\begin{array}{l}\text { Foiling: } \\
\text { vision } \\
\text { Head- } \\
\text { loches }\end{array}$ & $7 \frac{1}{2}$ & $\begin{array}{l}\text { Roughening } \\
\text { and thicken- } \\
\text { ing of cli- } \\
\text { noid proces- } \\
\text { ses }\end{array}$ & \begin{tabular}{|l|} 
Nege- \\
tive
\end{tabular} & $6 / 12$ & 6760 & Equal, & $\begin{array}{l}\text { ight } \\
\text { normal } \\
\text { Left } \\
\text { slow }\end{array}$ & Normal, & $\begin{array}{l}\text { Pallor of } \\
\text { both discs } \\
\text { more in left }\end{array}$ & Bitemporal & $\begin{array}{l}\text { Pituitary } \\
\text { tumor }\end{array}$ & $\begin{array}{l}4 / 26 / 21 \\
\text { Pituitory } \\
\text { cyst }\end{array}$ & $\begin{array}{l}\text { Pathological } \\
\text { report - Adeno- } \\
\text { ma, Necropsy } \\
4 / 27 / 21 \text {.Post- } \\
\text { operative } \\
\text { hemorrhege }\end{array}$ \\
\hline $\begin{array}{l}370484 \\
/ 30 / 21\end{array}$ & $\overline{40}$ & $\begin{array}{l}\text { Feiling } \\
\text { vision }\end{array}$ & 4 & \begin{tabular}{|l|} 
Finls.rged 4 \\
with erosion \\
of posterior \\
clinoids
\end{tabular} & $\begin{array}{l}\text { Nega- } \\
\text { tive }\end{array}$ & $6 / 60$ & $6 / 30$ & $\begin{array}{l}\text { Irregt } \\
\text { ular }\end{array}$ & Normal & $\begin{array}{l}\text { Fight } \\
\text { diver- } \\
\text { Eent } \\
\text { stre- } \\
\text { bismus }\end{array}$ & $\begin{array}{l}\text { Pallor of } \\
\text { dises with } \\
\text { loss of sub- } \\
\text { stence on } \\
\text { temporel } \\
\text { halves }\end{array}$ & Bitemporal & $\begin{array}{l}\text { Pituitary } \\
\text { tumor }\end{array}$ & $\begin{array}{l}9 / 10 / 21 \\
\text { Pituitary } \\
\text { tumor }\end{array}$ & $\begin{array}{l}\text { Pathologicnl } \\
\text { report - glioma }\end{array}$ \\
\hline $17 / 22$ ! & & & & & & L.P. & c.f. & $\begin{array}{l}\text { Irrege } \\
\text { ular }\end{array}$ & \begin{tabular}{|l|} 
Right \\
Argyll \\
Robert- \\
son \\
Left \\
normal \\
\end{tabular} & \begin{tabular}{|l|} 
Right \\
diver- \\
gent \\
stra- \\
bismus
\end{tabular} & $\begin{array}{l}\text { Simple optic } \\
\text { atrophy both } \\
\text { eyes }\end{array}$ & Bitemporal & & & \\
\hline $\begin{array}{l}1380367 \\
1228 / 21\end{array}$ & 33 & $\begin{array}{l}\text { Failing } \\
\text { vision }\end{array}$ & $I^{\frac{1}{3}}$ & $\begin{array}{l}\text { Destruction } \\
\text { of sella }\end{array}$ & \begin{tabular}{|l|} 
Nege- \\
tive \\
Nonne \\
posi- \\
tive \\
Lym- \\
pho- \\
aytes \\
33
\end{tabular} & $6 / 30$ & $6 / 60$ & $\begin{array}{l}\text { Left } \\
\text { larget } \\
\text { than } \\
\text { right }\end{array}$ & $\begin{array}{l}\text { Right } \\
\text { slow } \\
\text { Left } \\
\text { normal }\end{array}$ & Normal & $\begin{array}{l}\text { light, pallor } \\
\text { of nerve } \\
\text { head, Left } \\
\text { pallor with } \\
\text { loss of sub- } \\
\text { stance }\end{array}$ & $\begin{array}{l}\text { Partial } \\
\text { bitemporal } \\
\text { heminnopsia: }\end{array}$ & $\begin{array}{l}\text { Pituitary } \\
\text { tumor }\end{array}$ & & 点 \\
\hline
\end{tabular}


Group 2

Chart II

Pituitary Tumors with Acromegaly.

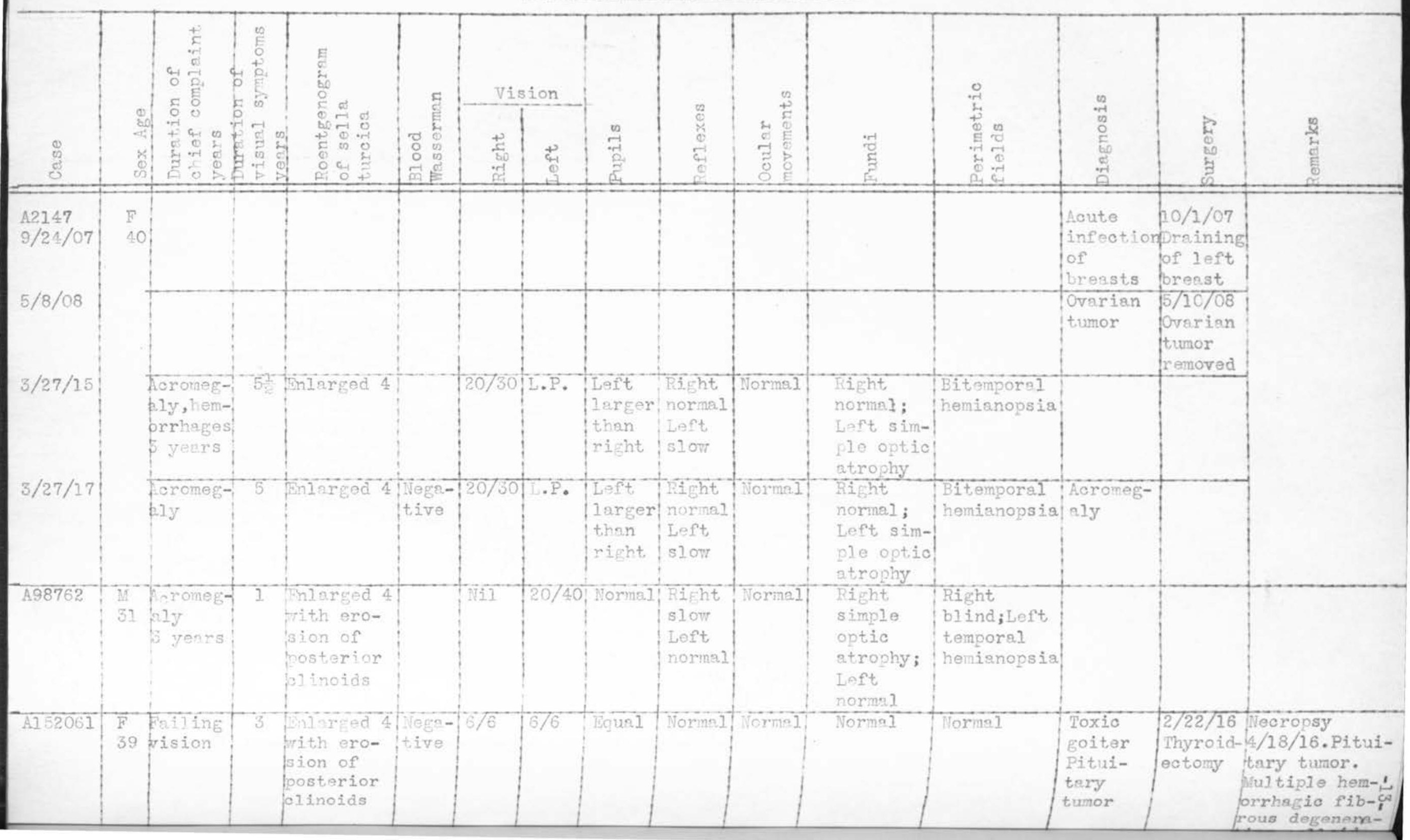




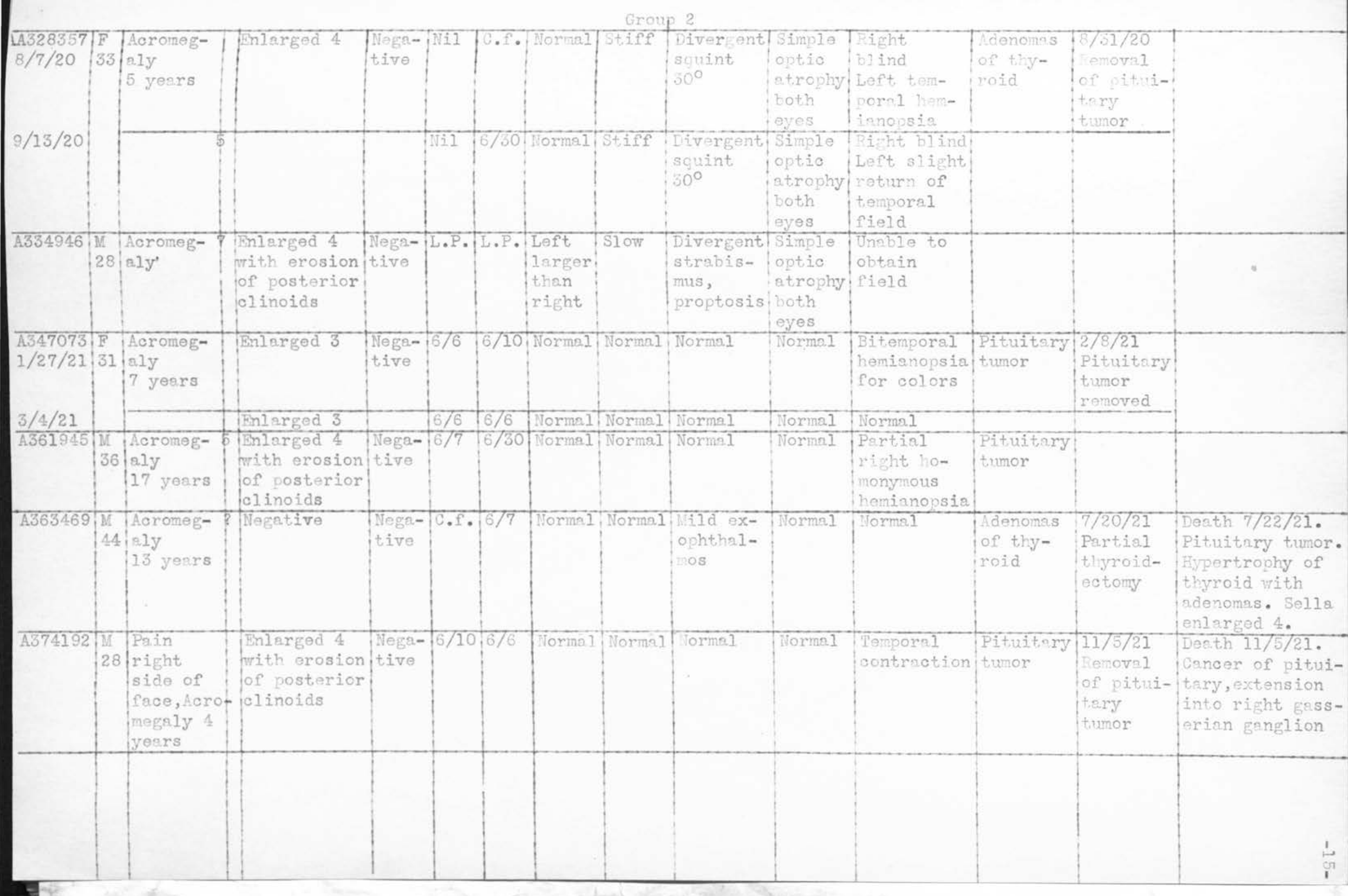



Plate 1

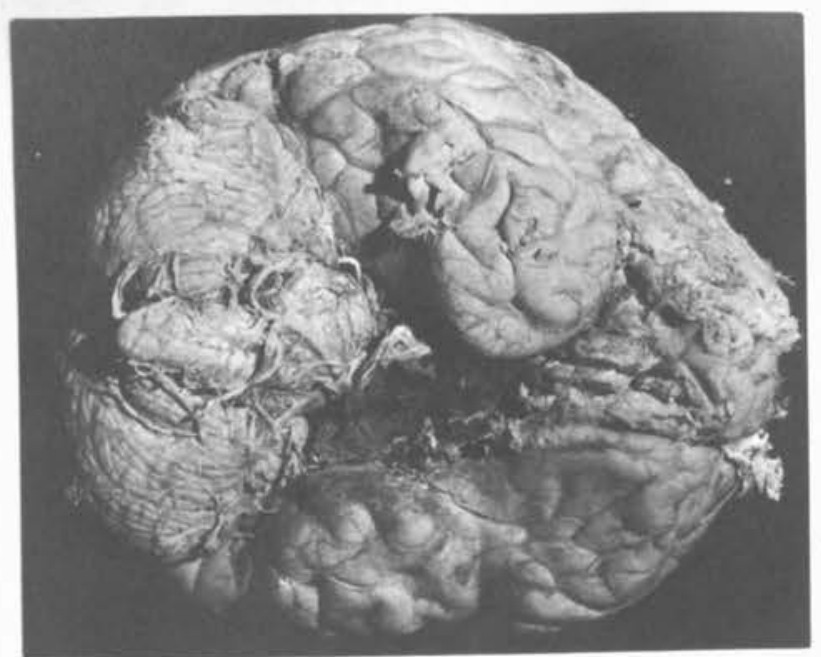

716.2.
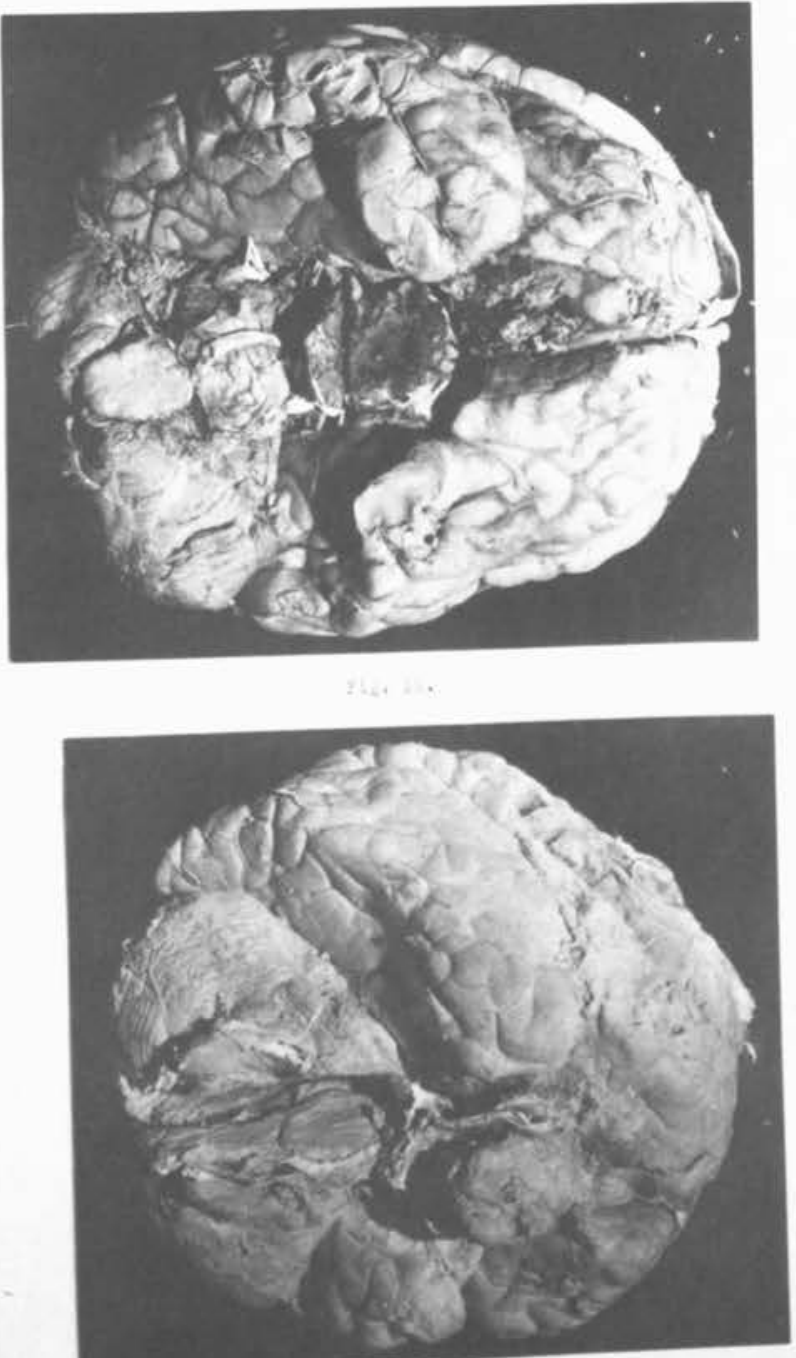

316. 211.

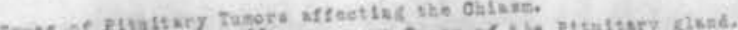

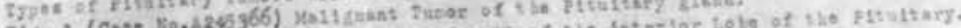

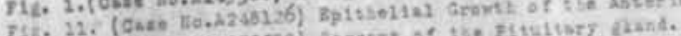

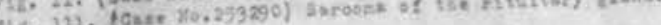




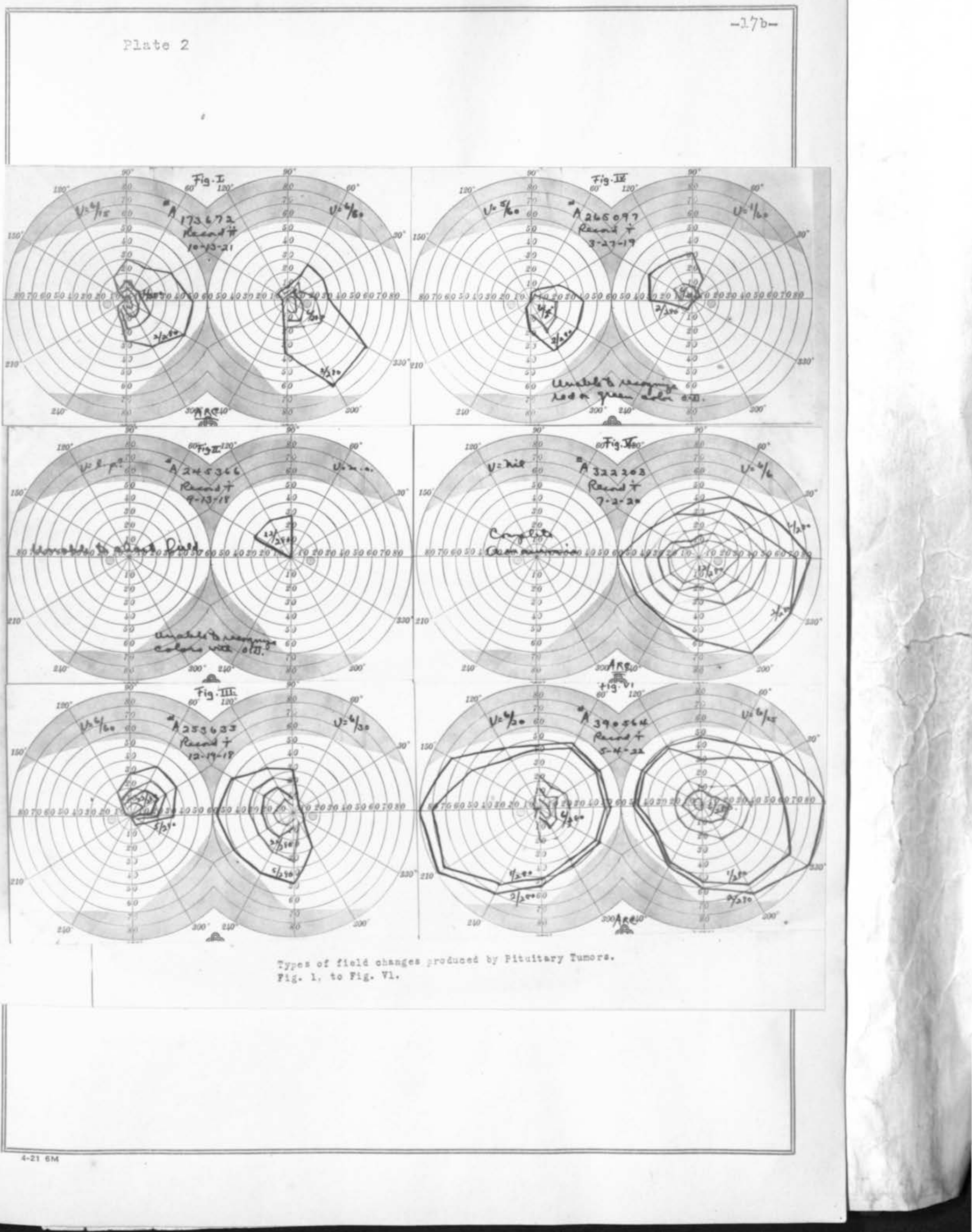




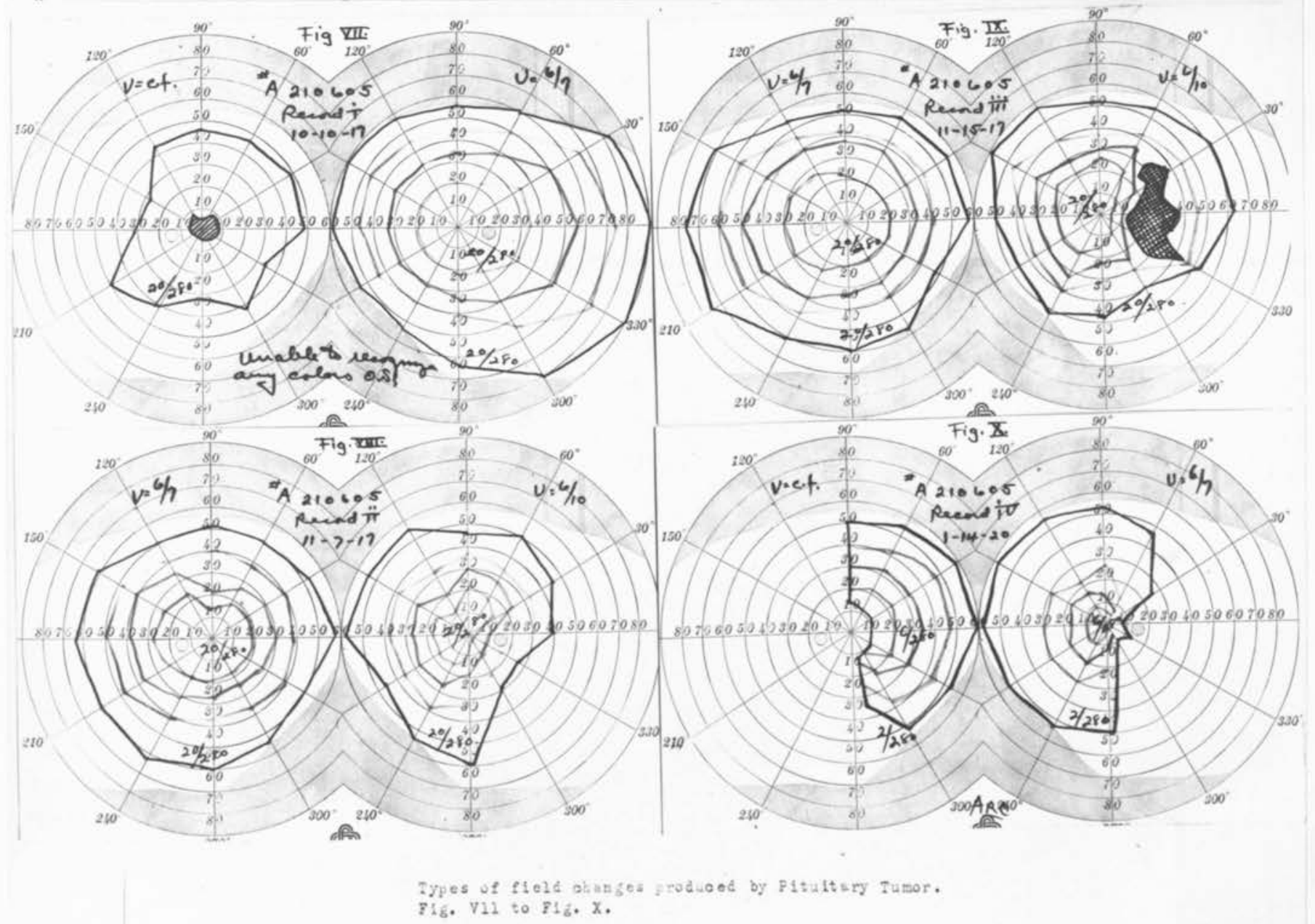

$\mid$ 


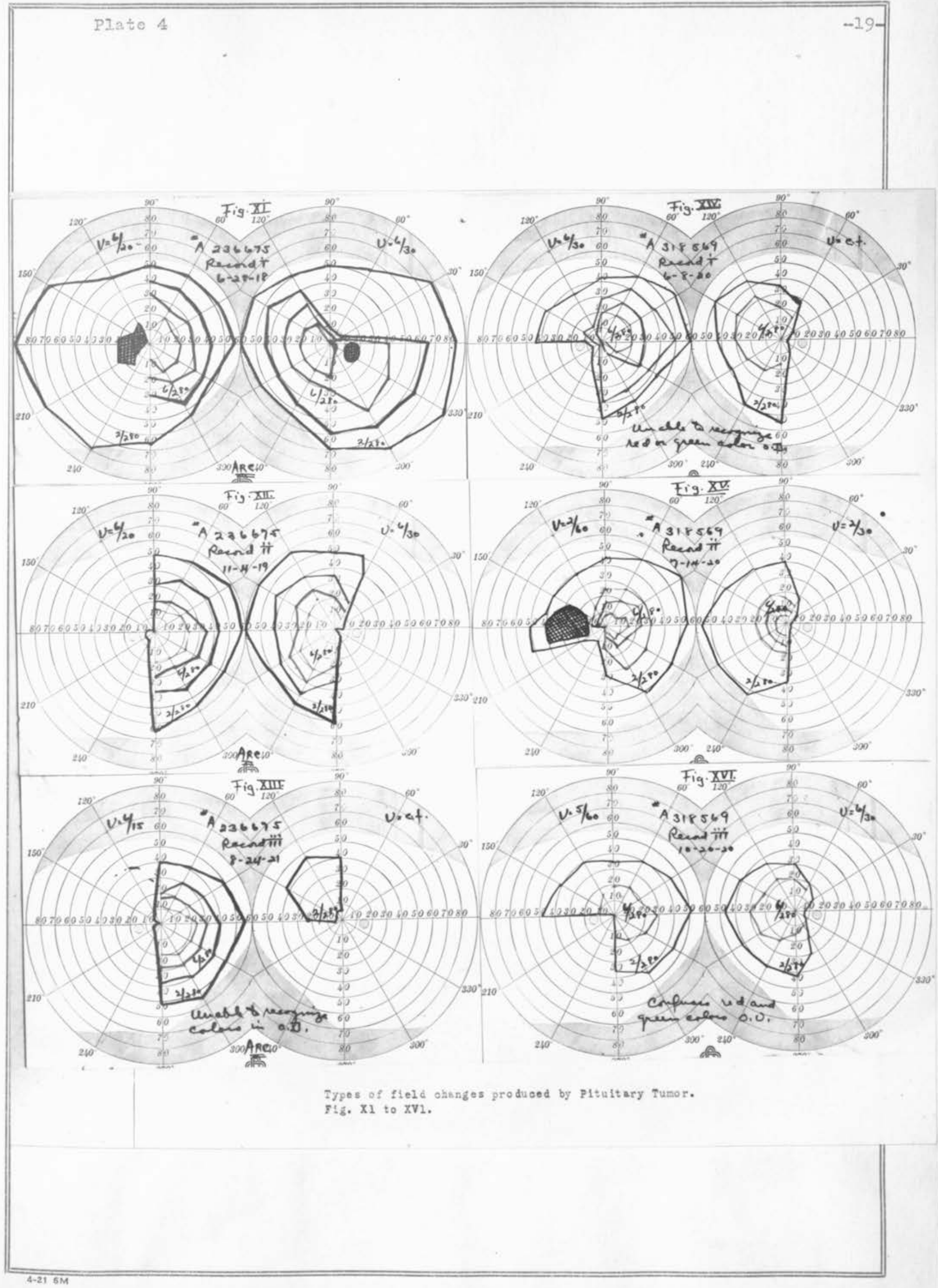




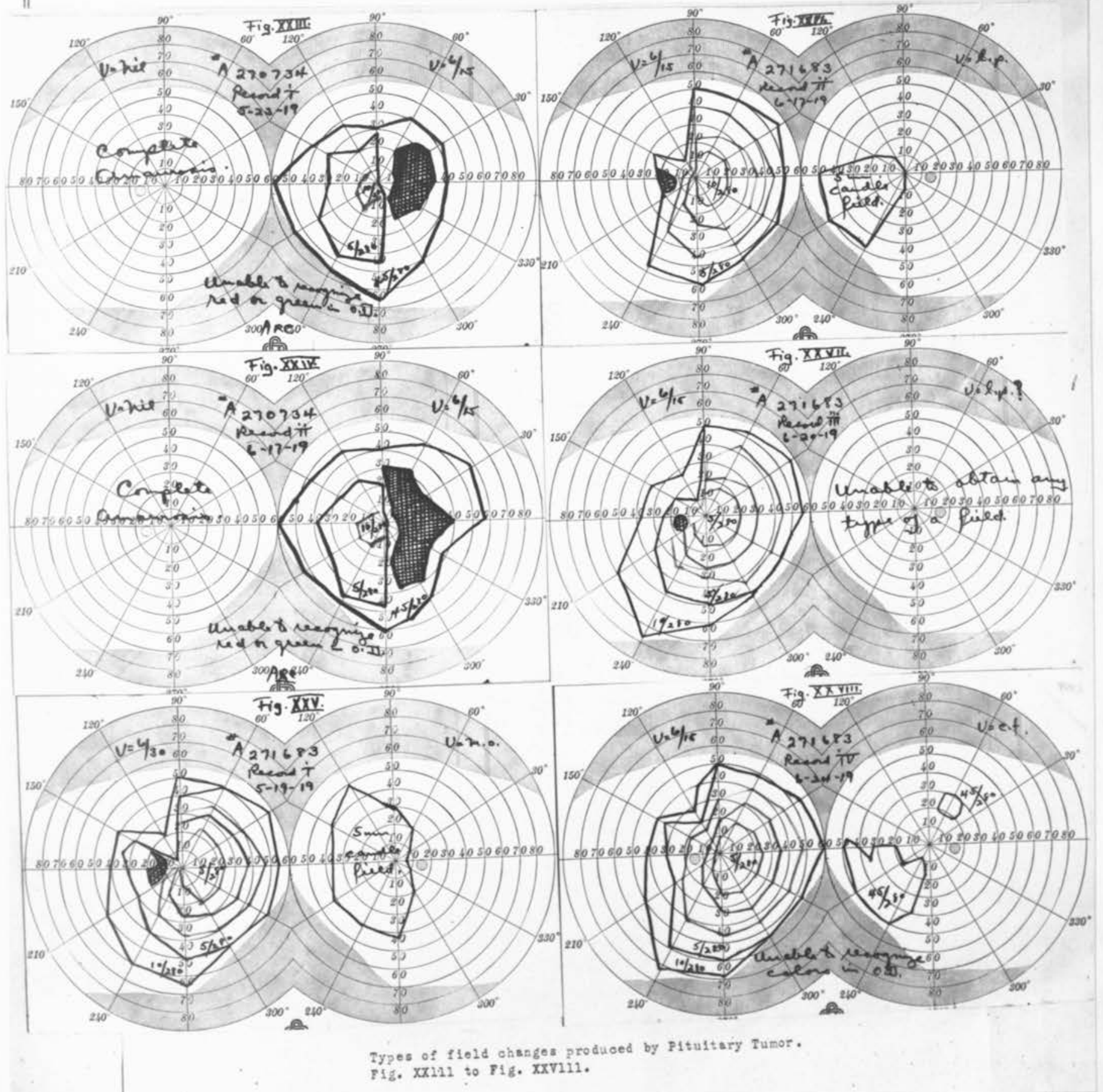




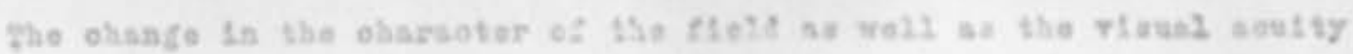

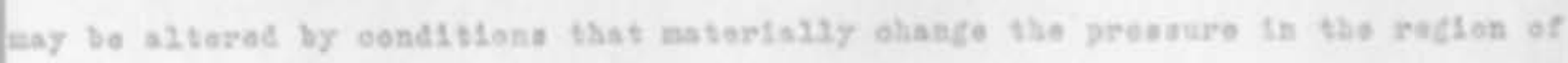

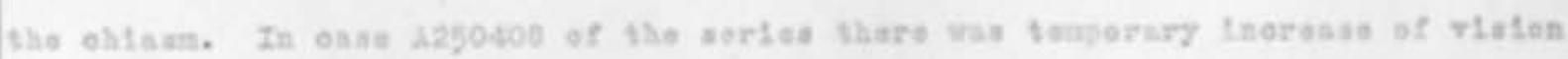

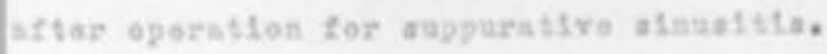

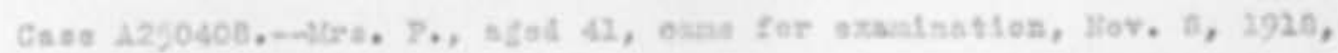

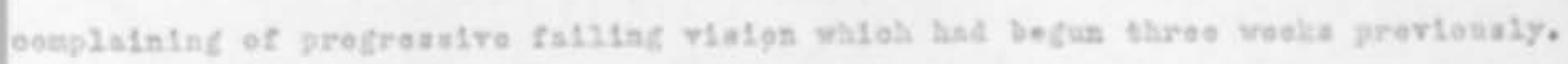

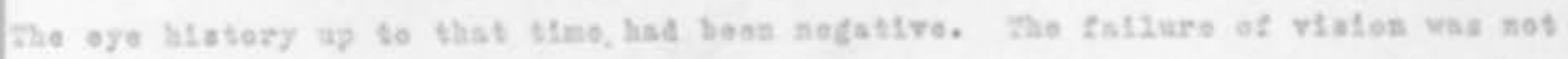

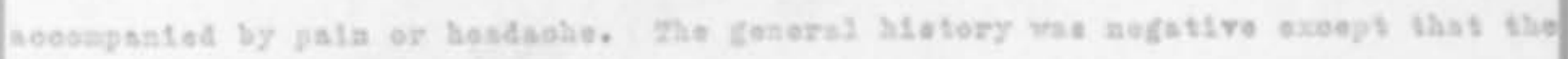

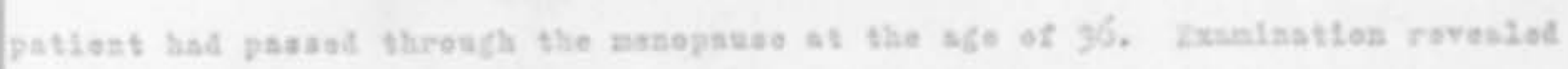

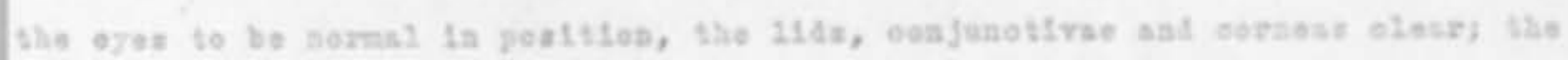

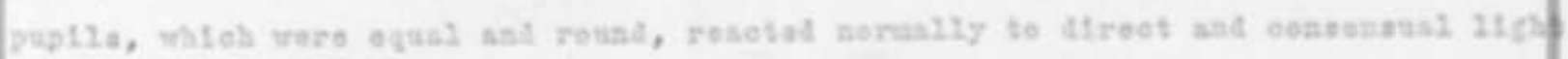

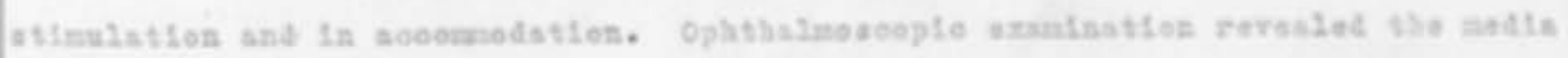

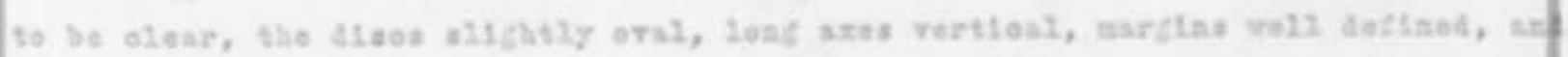

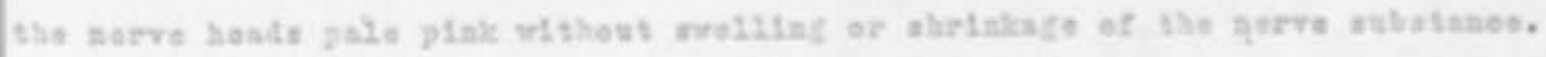

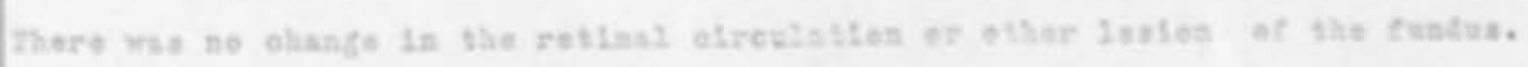

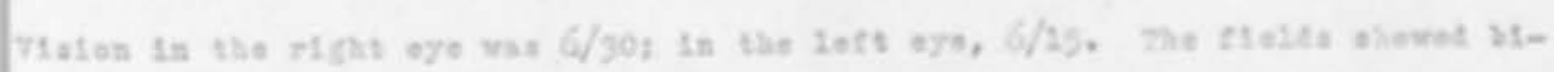

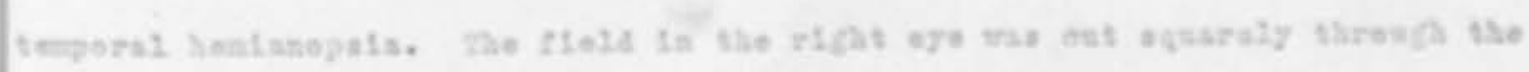

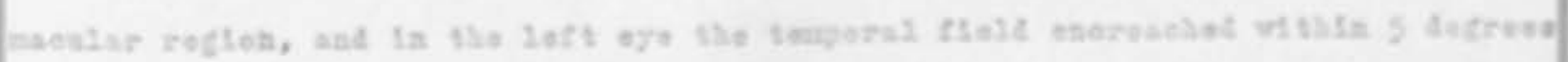

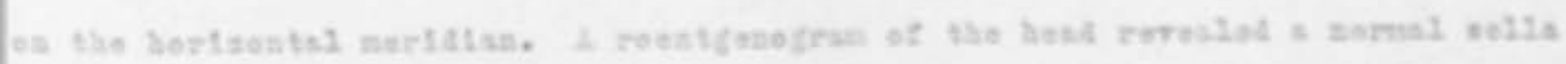

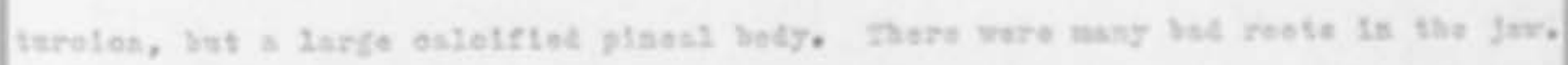

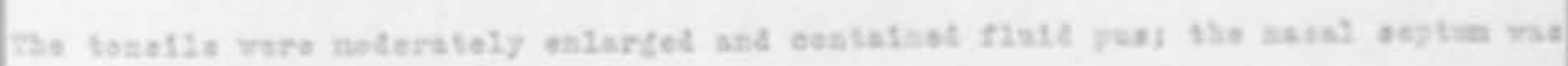

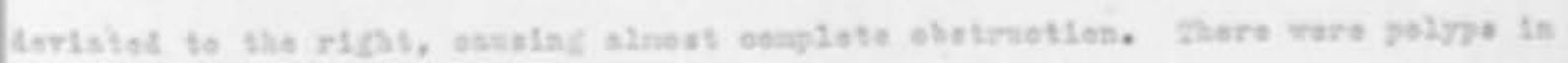

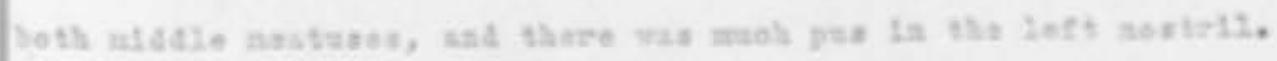

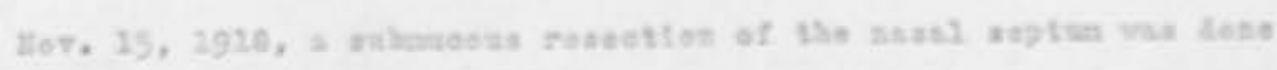

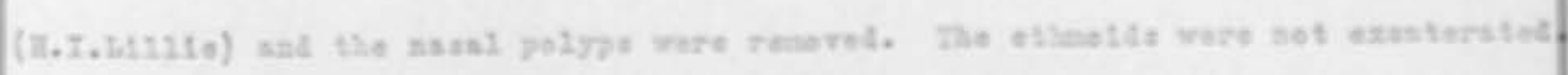

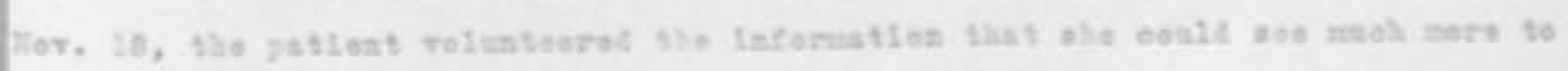

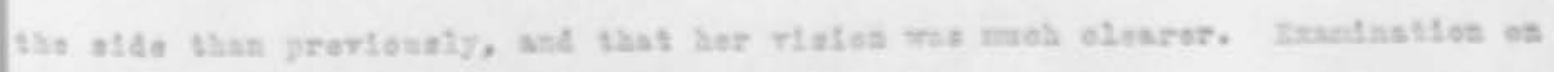

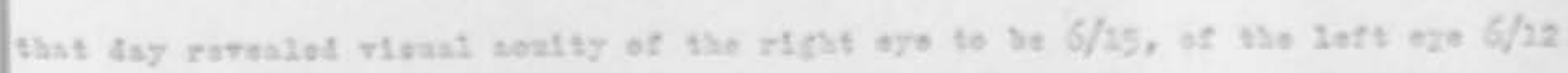

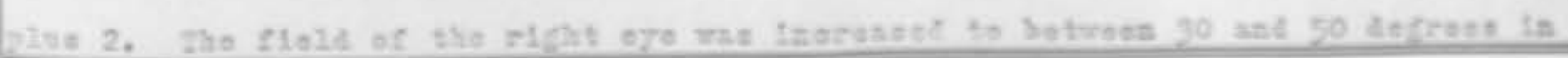


the lower outar quadrant, and the field in the left eye was inoreased unilormly to o degrees. This increase in the fields was mereit a relative increase, ohoming with a $22 \mathrm{~mm}$. test at $290 \mathrm{~mm}$. but not found when the $5 \mathrm{~mm}$. test objeot ras used. Tor. 23, the patient had a pan simus exenteration (right side). "The midale mettus and ethmoid labyrinth were filled with pus and hyperplastio tissue. The ctlmoid labyrinth geve the gensation of brittleness and was eritiroly exenterated. The sphenoid was entered and found to be affected. The antrum was irrigatod and foul pus vemoved" (H.I.Iilile). Hov. 27, the pationt stated that she oould see to read. The fields taken on thst day, however, showed no improvement; in fact, some of the relative field in hoth eyes had beon lost between the last two operationis. 10 eurther simu operations rere necessary. The vision had now improved to $6 / 12$ in the wight eye and $6 / 10$ in the leit. Deo. 18 , the reletive liold with 22 man. test object at $290 \mathrm{~mm}$. ras narror, and the patient had almost complete bitemporal hemianodsia with $6 / 12$ vision in the right eye and $6 / 7$ vision in the left eye. Feb. 19, 1919, she had complete bitemporal homianopaia, rith the lields dividod vertically just to the temporal side of tise point of fixstion.

A roentgenogran of the hosd showed the selle to be negative, but disclosed a large caloified pines. body. The nasal socessory simuses had been exenterated, following which the visual acuity improved and the size of the visual fields increased temporarily. Because of the appearance of the nerve heads (absenco of neuritis) and the visual pields, the patient ras operated on peb. 22 , 1919, for pituitary tumor (Adson). Non exploring the optic conmissure, the tumor was found bulging in front and pressing out laterally on osoh optio nerve. The upper portion of the tumor was very oystio, so that a depression was made on either side by the optio nerve. The tumor wss not adhorent either to tho optic nerven or commissure. About 2 drams of watery fluid escaped when the capsule of the tumor was opened." Jolloring this operation the fields returned prsotically to nomal both for form and colors. 


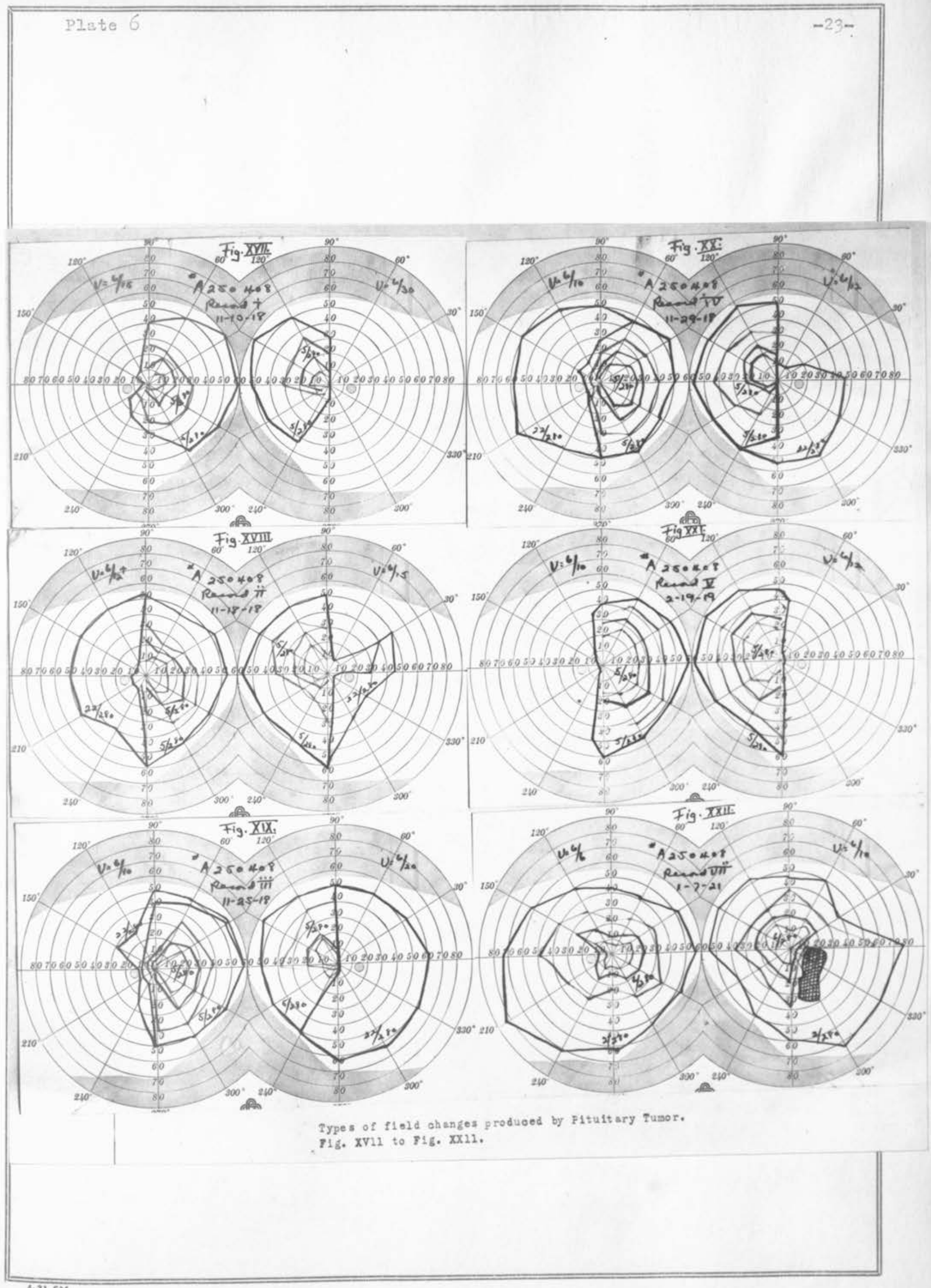




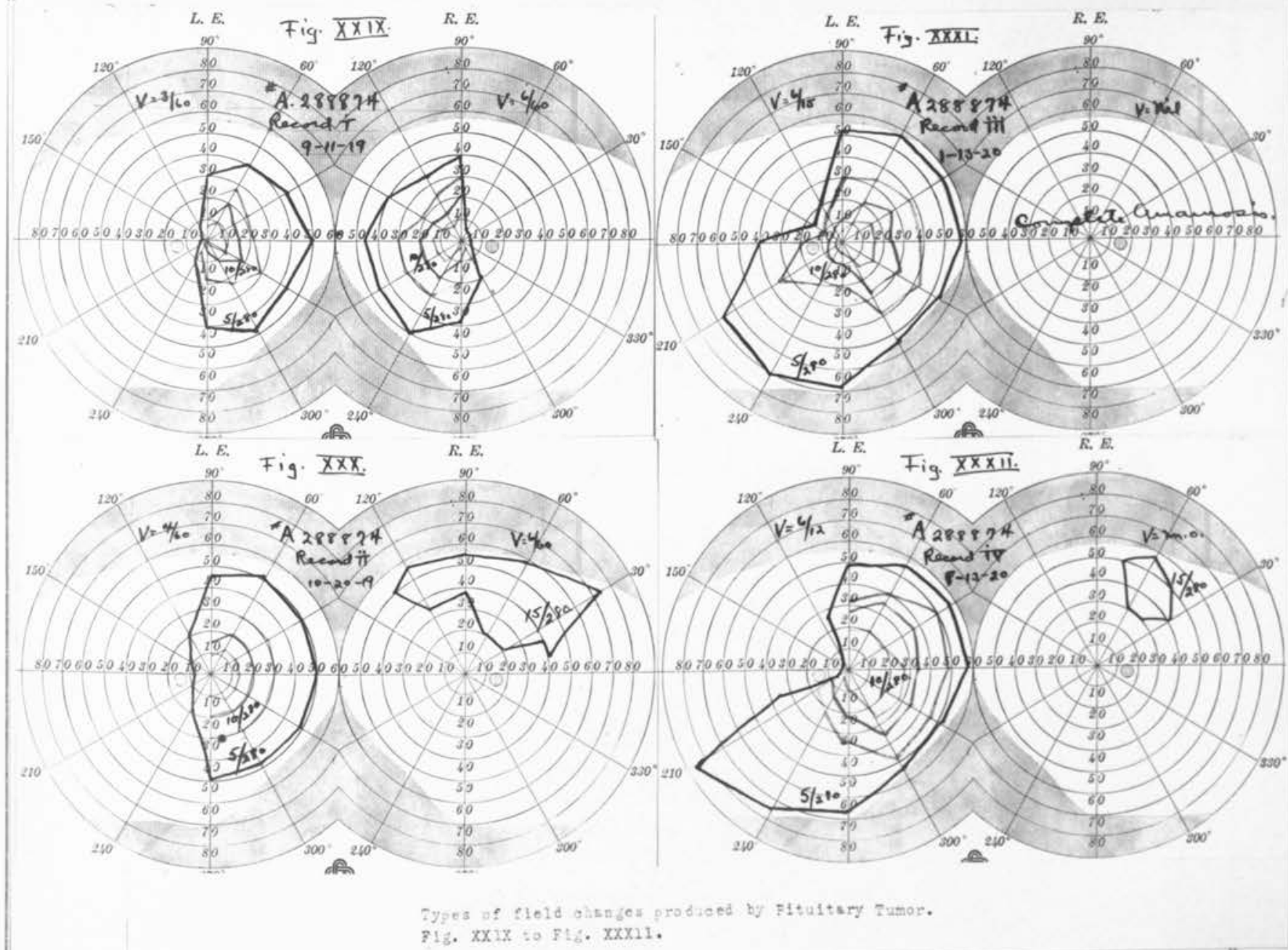




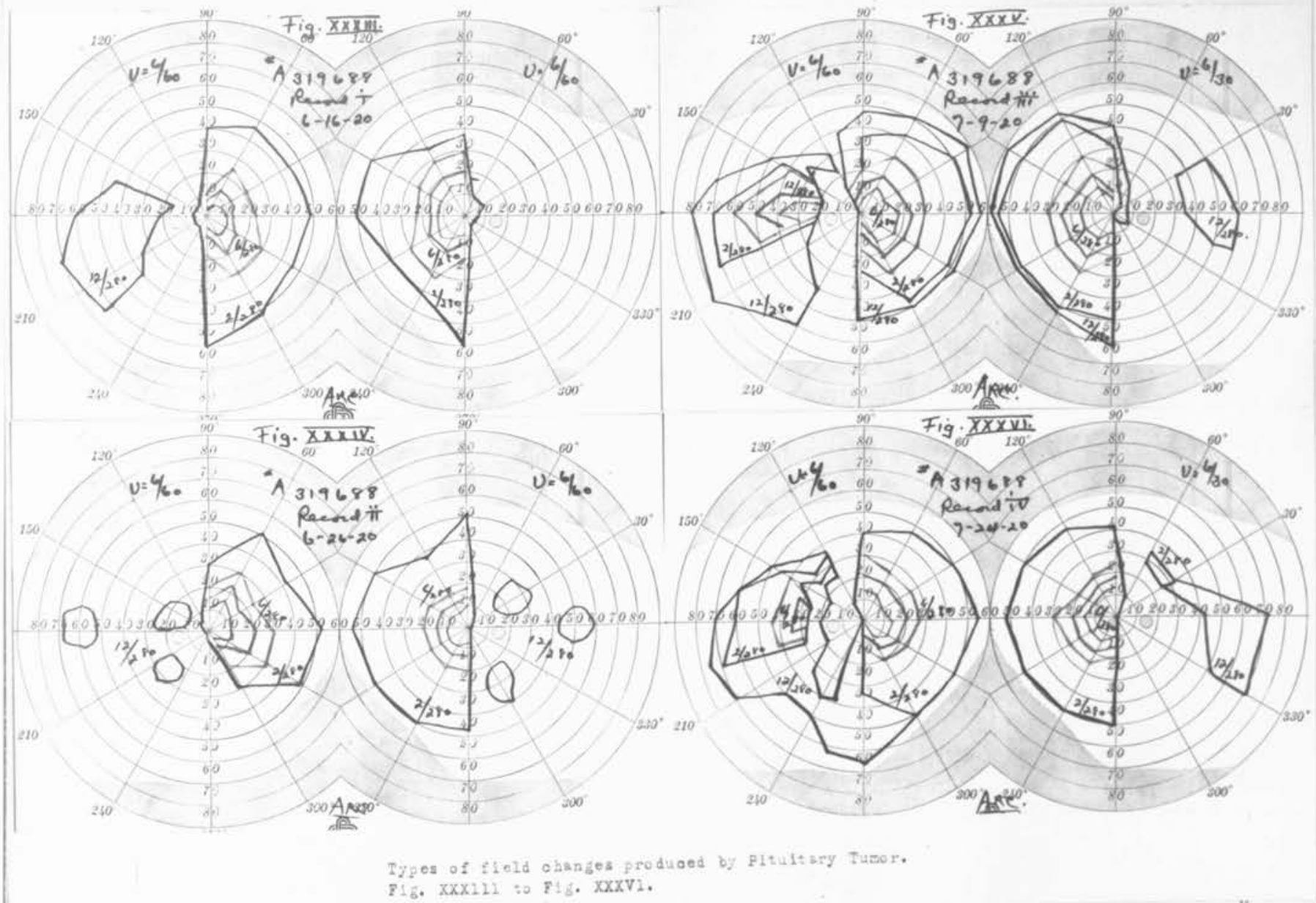




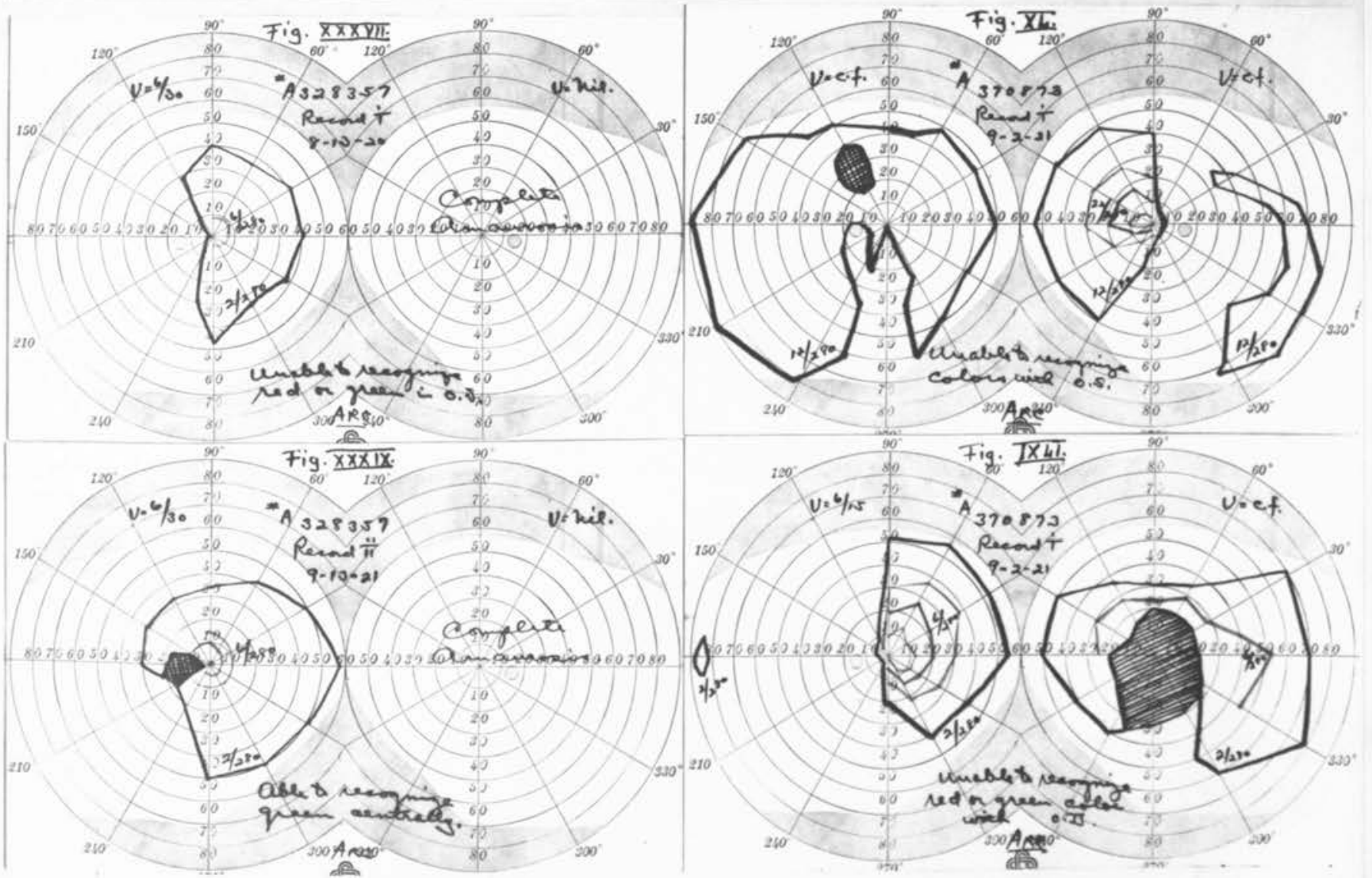

Types of fleld ohnges zroduoed by Pliultury Tumor.

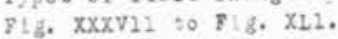




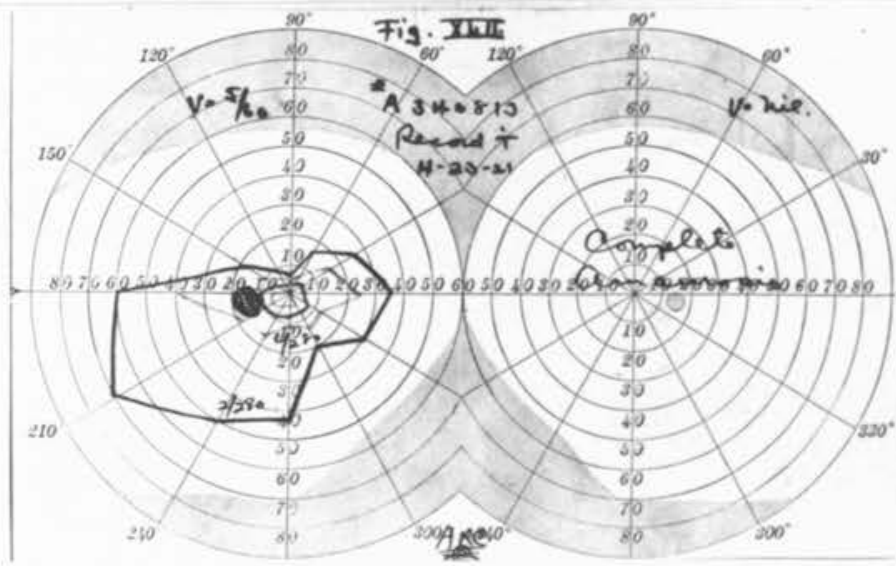
Name $A 3 H=813$
Fig. XIIII
Date $4-23-21$

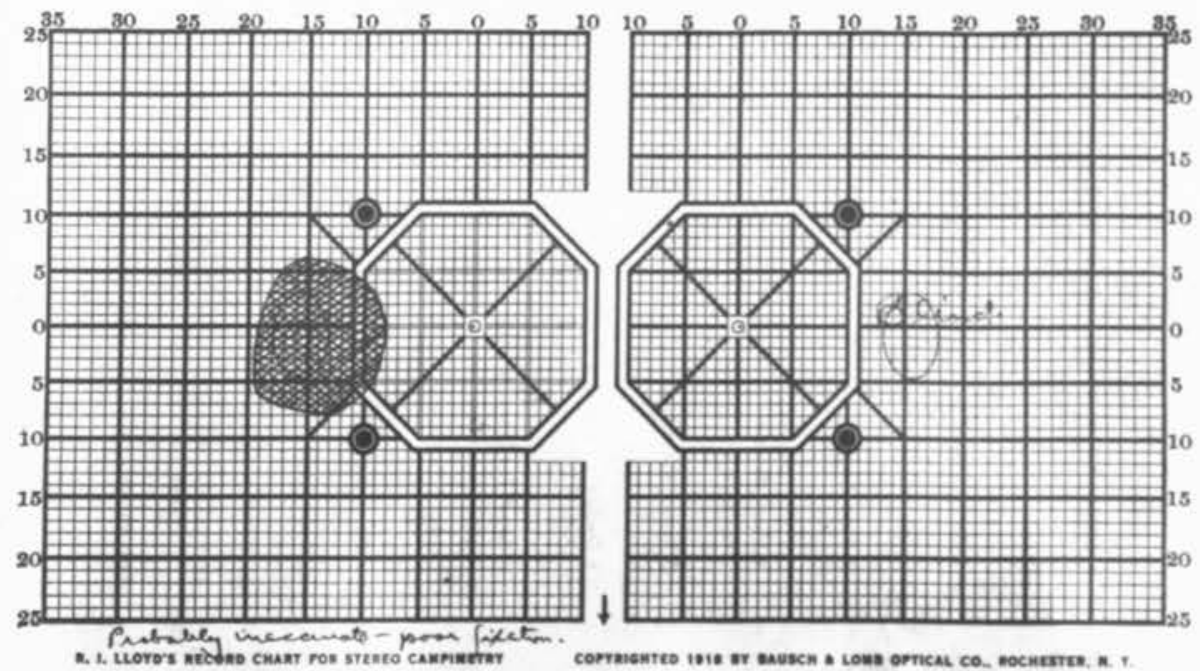

Types ff fleld ohanges produoed by P1tultary Iumor,

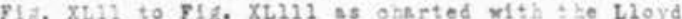

Stereo Campl-etef. 


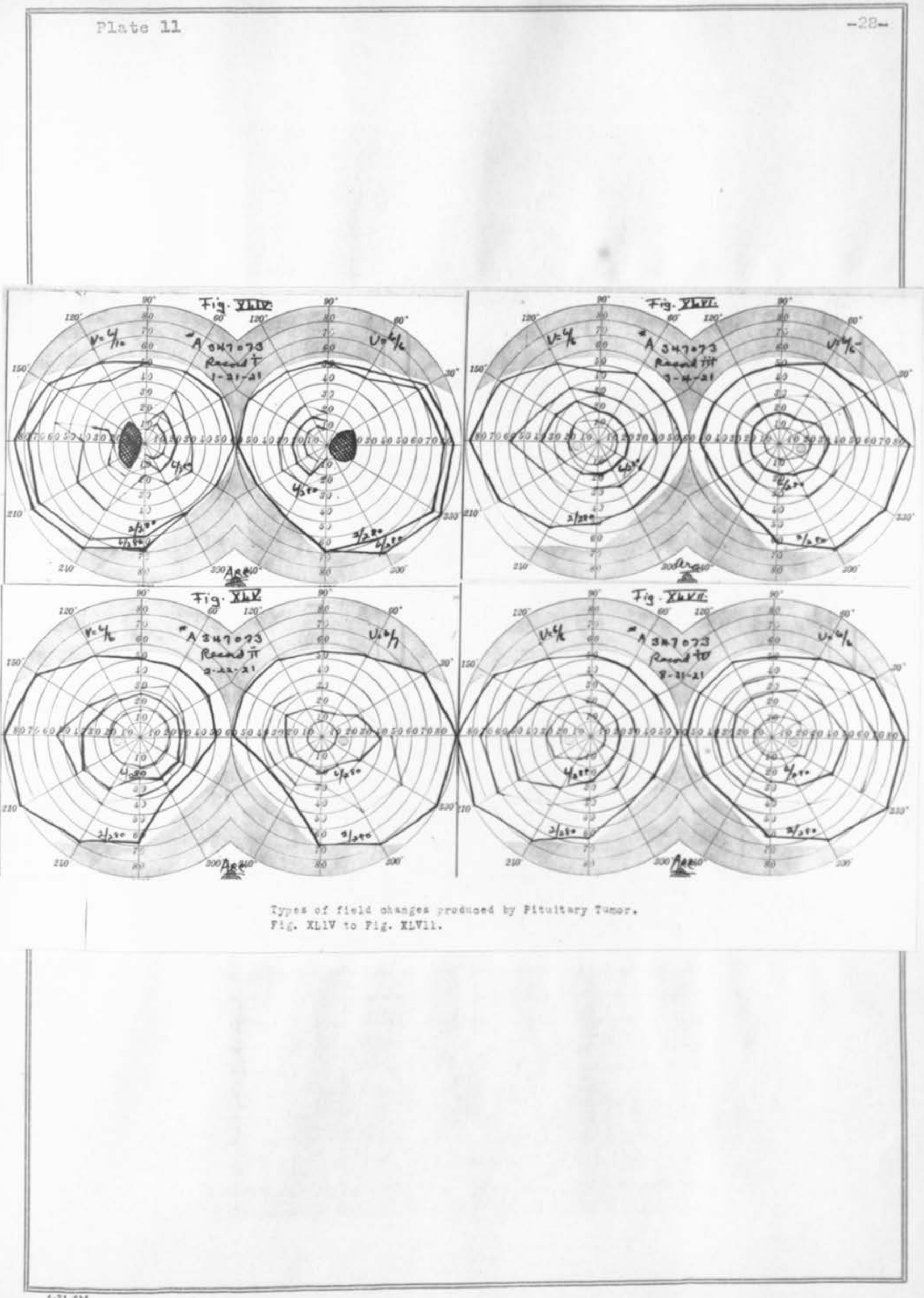




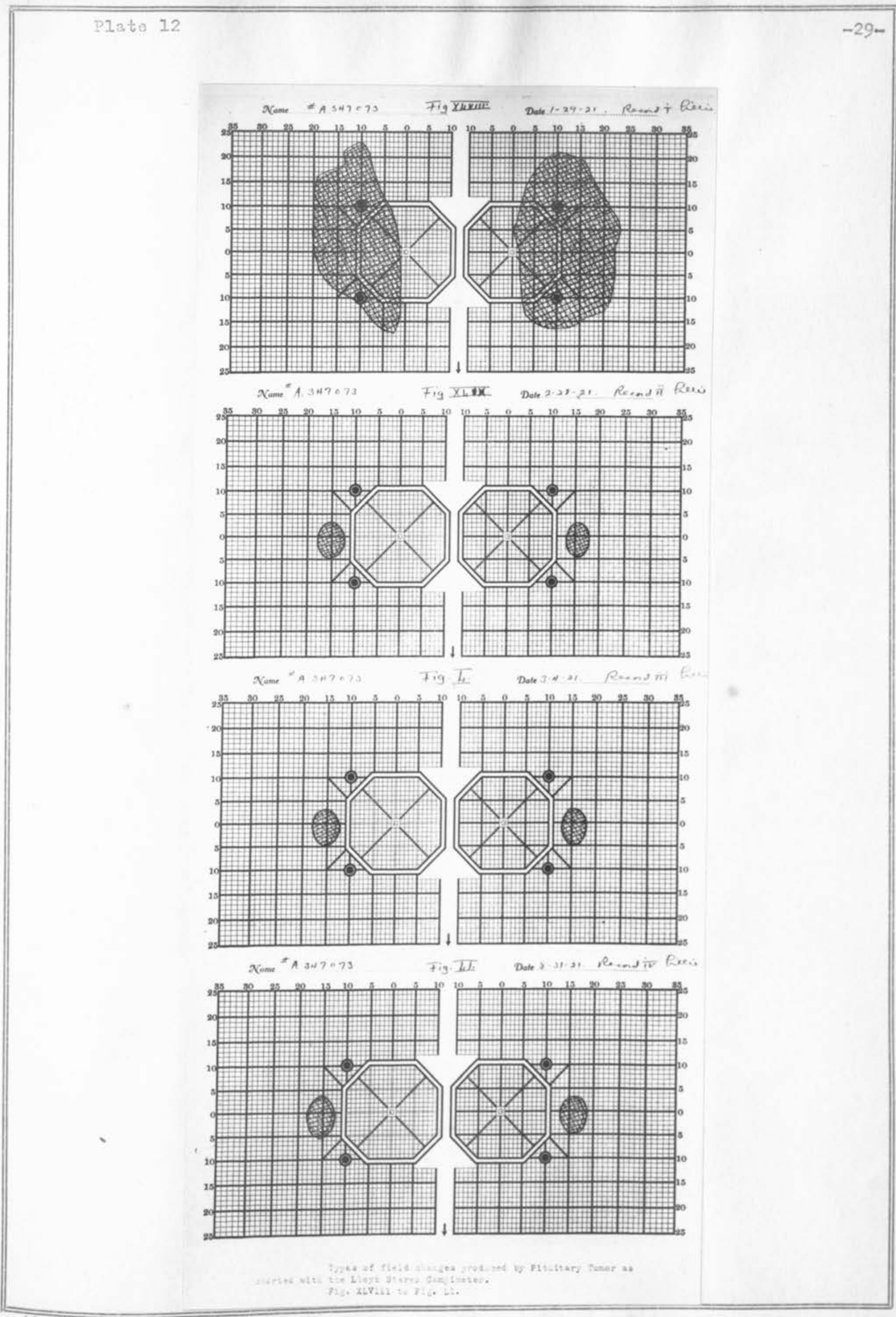



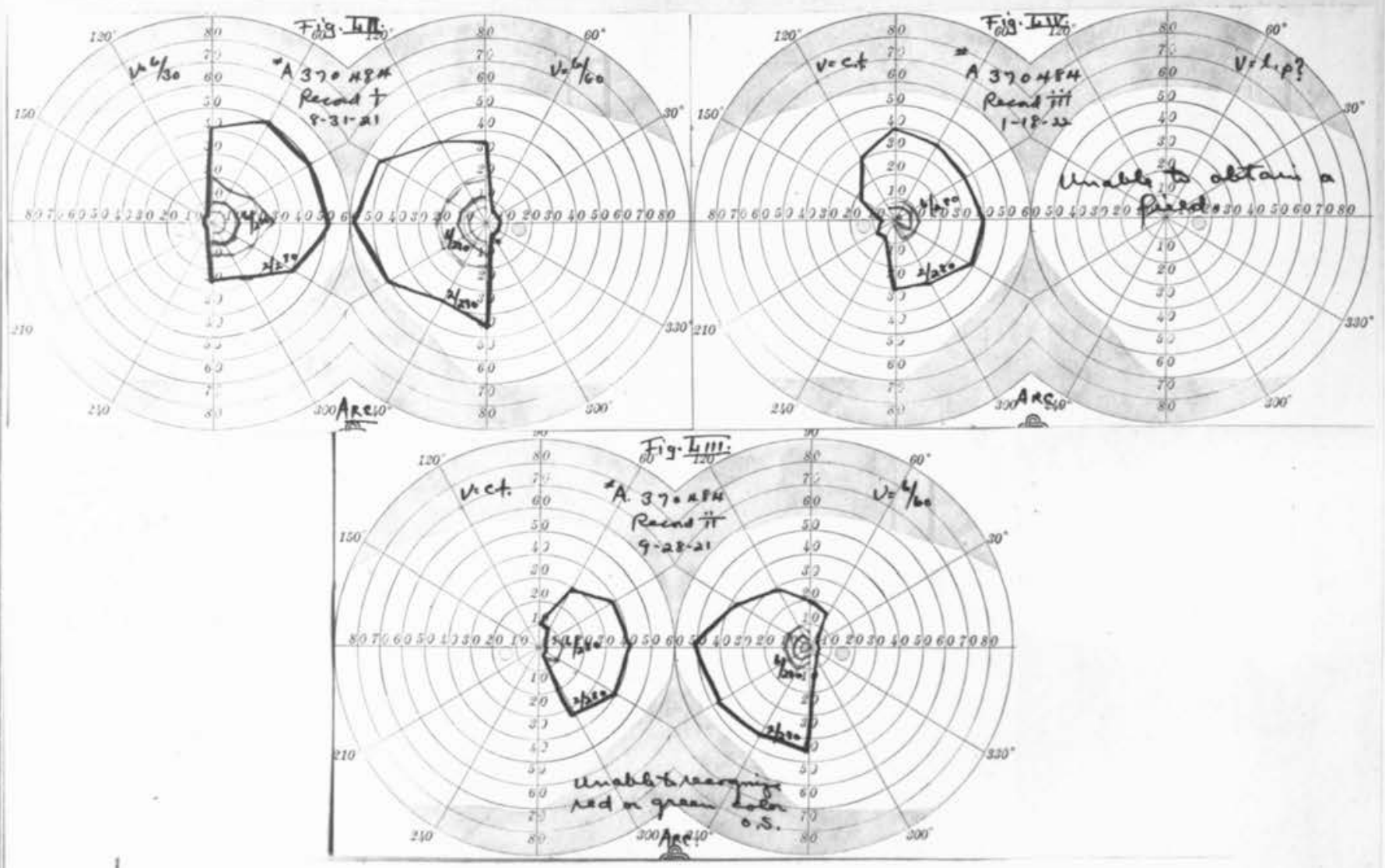

Zypes of $41=1 d$ ahsinges produoed by P1tuttary Tumor.

F! . L11 to 712 . LIV. 


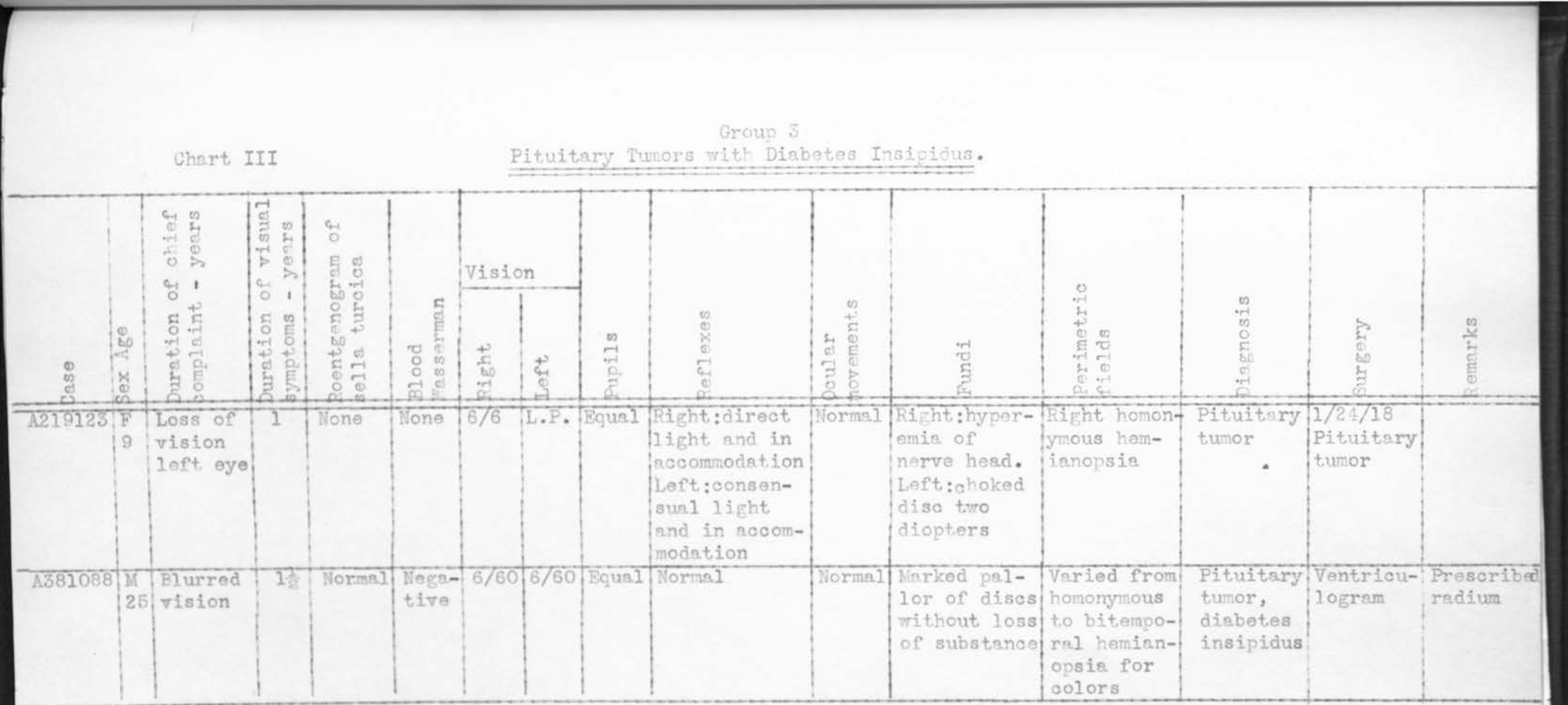



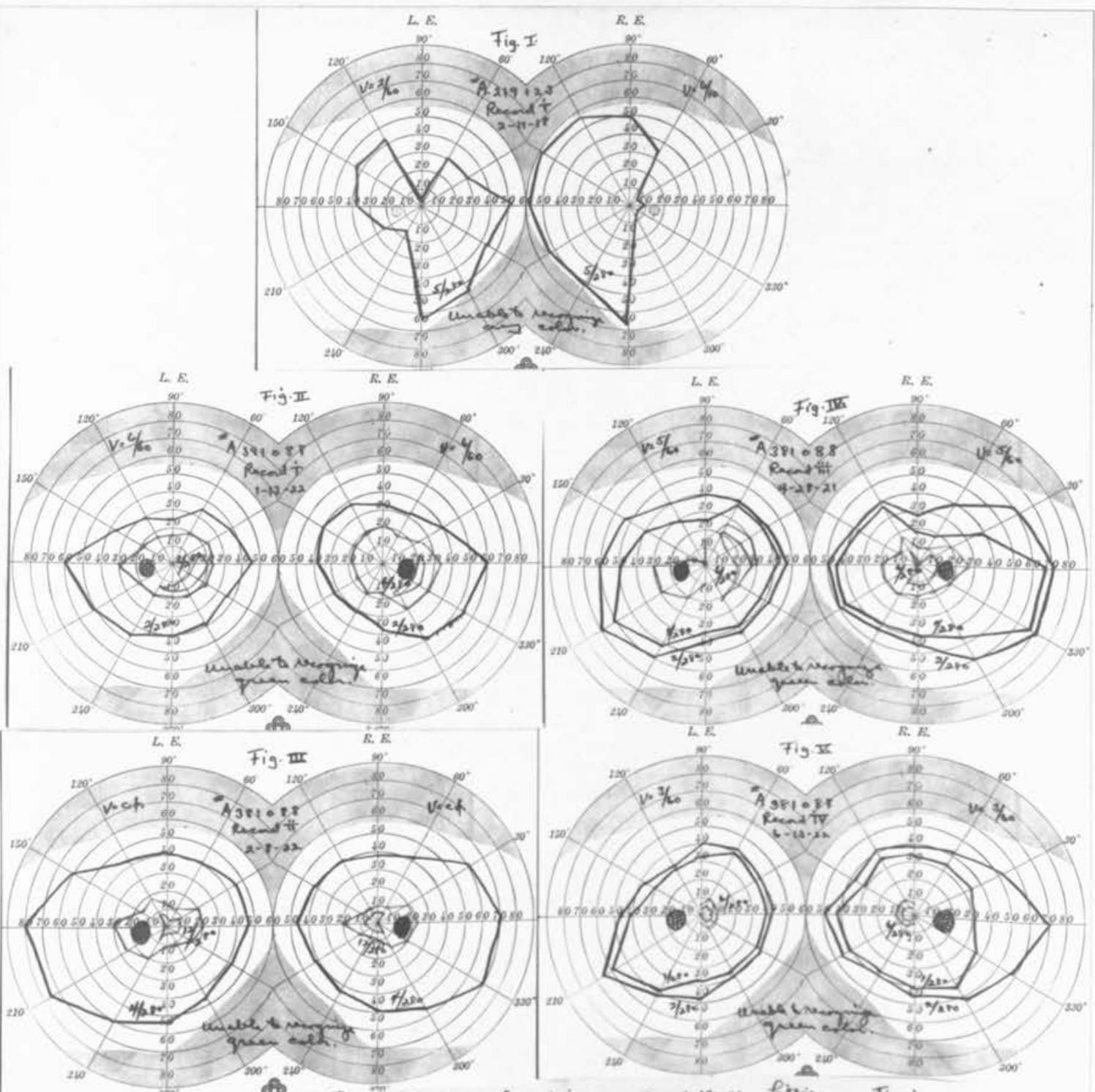

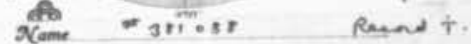

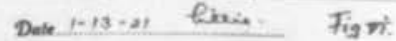

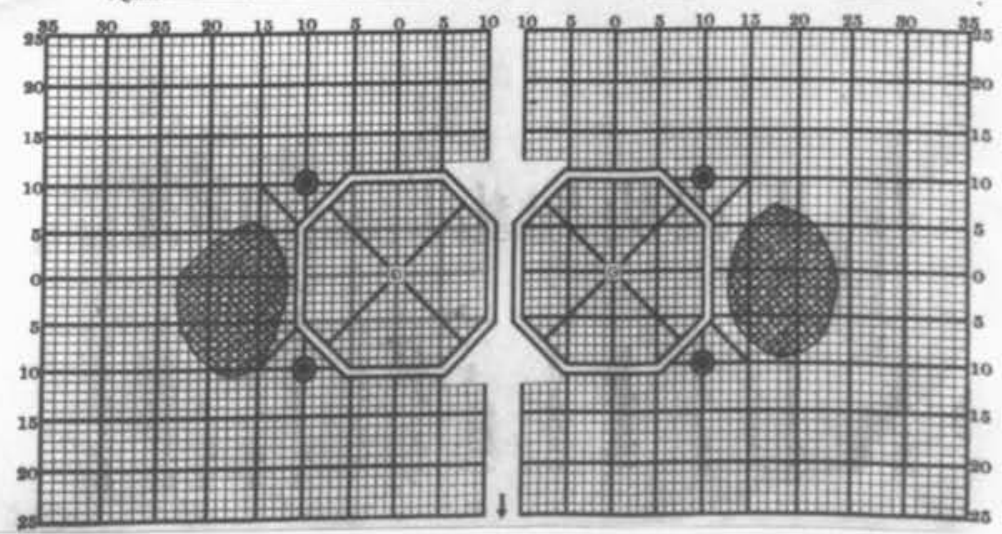

Instptate.

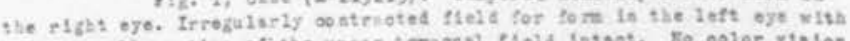

in elthes 5 ze.

sreatemat. 
The clasolfication of this type of tumor is most diffioult ss there are so. many different types of losions and the loostions are so varied, yet sll of these cases have produced more or less typioal chissma eleld changes. Many 1soIated osses have been reported of cerebral tumors produoing these defeots. Wilbrand and Saenger list the folloring locations of tunors causing chiasmal field changes: Tumors of the Sella Turoica, Interpedunoulated space, Pars Petrosa, Sphenoid Bone, Base, Temporal Lobe, Pedunole, Pozs, Pia, and Pineal Body. 4 Cushing in 1912 reported six heteroplastic or extrs-pituitary tunors out of a series of twenty-nine csses. Two were terstomas, two infundibular oysts, and one superimposed endothelioma. Isolated osses of de Sohvieinitz, Farnal, and Eumell, also desoribe different central lesions secondarily aflecting tho chisam. iveisunberg in 1910 colleoted trenty-seven osses from thio litersture and reported three oases of his ow of third ventricle tumors and established a symptom-oomplex for tumors of this origin. Unfortunstoly no perimetric flelas were recorded in any of these osses. Wilbrand und Saenger think thet eluotusting visusI aisturbsnbes are nore or less characteristic of tumors in this orisin. 2lost any type of ohiasmal field defeot could be found from a tumor or hydrocephalus of the third frentriole, and pressure exerted by the distended ventricle has beon quoted by Cushing and Walker in their report of binssal hemianopsis produoed by certified brain tumors which were ohiefly situated in the posterior fossa. Potor does not Bgree with Cushing and Walker that the binssal defects of visual pields produced oy the lesions as desoribed are due to ohiasmal pressure, as an altitudinal anopaid should also be present in such oondition. Ho is of the opinion thst the pathology is at the optic diso and not st the ohisan and is seoondery to the oontinued choleing of the diso. In 1921 the author reported six osses of intraoranial lesious pot of pituitsry origiz.

The cases reported in this paper have all been certified either by pperstion or neoropsy and have sflected the oiliasm by direct extonsion and not by 
remote secondary effects such as inoressed intracrsilal presare. They have been of suffioiont interest to report in detail in order to show how easily one can be lead into an erroneous diagnosis by the ophtholmologic findings. The aimilavity of this group and those of pituitary tumor is rery striking. Group 4 osse report.

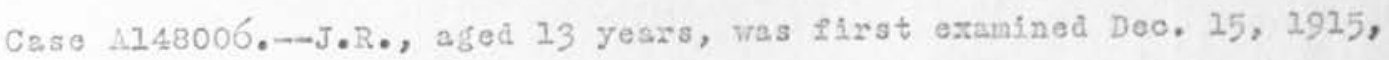
chiofly because of severe pains in the head with voniting and unnstural gaft. As a ohlld the patient had always been backrard mentally. Since birth the patient'a gait has been peouliar. In July, 1915 he began to complain of pain in the baok or his head which has become move severo and moro erequent. The pain was gonerally accompanied by sudden projectile romiting without any relation to his mesla. Since July he has had a mild exophthalmos in each eye. Duxing the attacks of pain his hesd would be drawn backward and he rould gradualy fsll fomrard or to one side. Patient never had a generalized convulsion.

The general examination was essentially negative throughout. The nose, throat, and nasopharymx were negative; Wassemann resotion on the blood was negative. The roentgenogram of the hesd showred the sells turoios to be greatly onlarged vith erosion of the posterior olinoid procosses. The vision in each eye vas barely light perception. The pupils were equal snd the right did not resot to any type of atimulation, the left reation was typiosily Arfyll zobertaon. There Fas a slight diverfence of the left eye. The fundi showed a seoondary optio atrophy of both discs, otherrise negative. The perimetrio flelds oould not bo obtalnot beosuse of marled diminution in vision.

The neurologicsl disgnosis was corebellar tumor. A puncture of the corpus oallosum and the right lateral ventriole was done Dec. 21, by Doctor Beclann. The patient died three days later and at nearopsy a large tumor of tire optio oommissure was found. There was also a bilaternl internal hydrocephalus and congestion of all the parenolymatous organs.

Case A152904.-mlur. M.R., aged 20 years, was first exanined reb. 24, 1916 becanse of blindness in the left eye. He had complained of poor vision for two 
years with diplopia and frequent hesdaches. Glasses improved the condition for nine months, when he had a very hifh fover with vomiting and headaclie, and within three or four hours total blindness in the leit eye. The right eye had been normal until two months before examination, when vision had become "smoky" and he could not see to read or write. The headaches persisted over the eyebrows, but thay were not so erequent. He had romited only oroe or twioe during the last three months. He had lost slightly in veight.

The general examination was negative. The roentgenogram of the sella turoios wss negative, and the Vassemann reaction on the blood was negative. Viaion in the right eye was $20 / 70$, in the left oye nil. The right fundus was negative, but the left fundus showed a complete simple optic atrophy. Perimetrio fields showed a temporsl hemianopsis in the right eye. The neurologic exarninstion vras negstive except for the ophthalmic pindings. A disgnosis of questionable pituitary tumor was made.

March 23, 1926 s right subtemporal decompression was periomed. (Dr. Beolman). Considerable cerebrospinal iluid escaped, but it vas not undor muoh pressure. The patient was dismissod after an unevontful convalescence.

Jan. 21, 1920 the pstient returned to the clinio beosuse vision in tho right eye had falled sinee his previous visit to the cIinio. He had had periods in which the vision was poor, but generally the rision had remained good until the last few months, whon it had failed stesdily. zxsminstion revesled the vision in the right eye to be $3 / 60$, in the left eye nil. The pupils were equal; the $x 1$ ght pupil reacted promptly to direct 1 ifht and in acoomodation. The right nerve hesd was greenish white throughout without loss of substanoe; the arteries and veins were nomal. In the left eye the media were olesr; the nerve head ahoved a narked pallor without loss of substance. The patient aeveloped a nild attack of influenza and was in bed one week. A slight cough persisted, and he felt weak, although his appetite improved steadily. The general examination after influenza was negative except for a mild bronchitis. The roentgenogram of the head showed the sella 


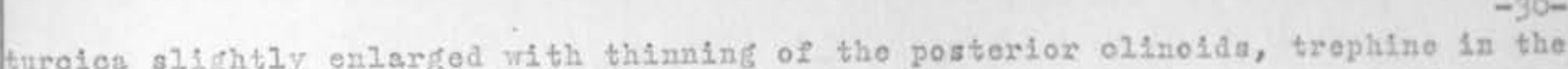
pight temporal region. The neurologio examinstion was objeotively negstive axoept for eye eindings. The metabolid rate was -7 per cent. A diagnosis of pitultary tumor was made. The patient returned home to recuperate erom the ineluenas before operstion.

The second operation was perfomed lay 11, 1920. At this time the v1alos In the right eye was $1 / 60$, in the left eye nil. The fundi wore the anae as preFiously reported. Dr. Adson opersted, and reported 21ndings as follows: "A mas Tras found situeted between the optio podunoles and extending undernosth the brain. This msas ras darle red without definite cspsule, and did not come dorm into the sella, but up between the pedunoles, spreading them for s distanoe of 3 om. Some tisauc was removed for diagnoais, but the tumor oould not be ronoved." A disgnosif fras unde of supratentorial bassl tumor. The patholobiat reported malignanoy. Tho patient died Kay 13, 1920; necropay mas refusad.

Ophthalmologiouly this case could not bo difforentistad from thst of pituitary tumor. It is intoresting to note that the selis ahoved no ohange so far as could be detemined by the roentgenosram unt1l noarly five yensa sfter the onaof of the risual symptoms.

Case A298592.--Mias B. I., aged 33 yeara, wras oxsmined Deo. 2, 2919 boosuac of 1033 of vigion in both eyes. Radiun trestment in April snd in June for fibroid tunor of the uterus had controlled the hemorriages she had hsd orery month. July 1 she awakened with blurred vislou in both eyes; this fradually from vrorse untsl she was only sble to resd the hesdisnes in the paper. Sho was able so ooztinue her work, checking largo fifuros, until ootobor 18. In walking ou the streof ahe often bumped into persons coming upon her left slde, but she' was sblo to sco them in iront of her or on her right side. The leit eye beosne troma more suddenlf than the right. For the last five veelss she had been unable to deteot 11 fht. During the last two weeks ahe had had threo attsoks of loss of oonaciouanoss. She crom of one attack, and this cusced her more anxiety than the blindness; she was 
not told of the other attaois. The attaoks ome on in the night, with deop breatif Ing and frothing at the mouth. She was not figid, but she could not be aroused for one-half hour; the next day she was very tired. For the last five weoks ohe had been conscious of a peouliar odor, as of ooal-gas, for half a seoond or go, with a peoulian sensation in her nose ana on the right side of her throst.

General examination revealed uterine fibroids. A roentgenogram of the sells turcioa showed it to be normal. The roontgenosram of the chest revealod slight bronchial thickening. The Wasscmann test on the blood ras negutive; the naso-pharynx was negative. The eyes were romal in size, shape and position. The pupils were dilated equally and reacted slusgishly to Iight and in acoomodation. Vision in both eyes vas nil. Dxamination of the fundus in the right eyo revealed a pink nerve head, the margins of whioh were slightly blurred at the outer and lower border, but no swelling; in the left eye the nerve head was pink and oblong in shape; otherrise the funai were negative. A lotter from Dr. Litohifeld, of Minneapolis, stated that sept. 23 the pationt had had a temporal homianopsis in the left eye and temporal hemianopsia in the right eye, with contraotion of the nasal field. The neurolofic examination revealed a statio tremor of the tongue, hands,arms, and legs. Deep reflexes vrere increased. The Babinsly reflex vrs positive on the right side; the Oppenheim, Rossolimo, and Gordon reflexes were positive on the left side. The Barany teat suggested pressure above the atem sad benoath the cortex (subcortioal). The diagnosis was tumor in the region of tho pituitary, probably partially above the chissm.

Dec. 12, 1919 the patient was operated on by Dr. Ldson. The notes dictated at the time of the operation are: "A tumor was found between the optic pedunoles; the line of cleavage between the brain and tumor ooula not be dissected. The left pedunole could not be seen. The right peduncle vrs about four tines normal size; its outer sureace was purplish and looked as if it might oover 3 tumor or hematoma. In the attempt to enucleate the tumor by first openlng tho ospaule severe arterial hemorrhage developed whioh was diffioult to control. Only 3 por- 
tion of the tumor was removed". The patholofiet's report was glioma.

The patient died the evening of the operation. On neoropsy a glioma of the middle brain was found infiltrating the optio tract, vith marked inoreased intracranial pressure and herniation of the right temporopariotal 1obe. The sella turcios was unusually deop.

The ophthalmologio examination in this oase gave no sugfestion ss to tho locstion of the tumor. At the time of our exemination the patient's vision ws nil and no visual fields could be obtained. The bitemporal hemianopis reported to $u s$ and the normal nerve heads found at our examination led us to believe that the patient had a chiasmal lesion. The neurologio examination revealed a definite looslization of the tumor.

Case A317083.-D. 0., aged 28 Jears, was exanined Hay 25, 1920 ohiofly because of failing vision in the right eye. The patient was well until ootober 1929; at this tine he suffered severe pain in the region of the inner oanthus of the right eye during the evening. The nert morning patient notioed the right upper Iid drooped considerably and since then there has been no improvement and the eyesight has failed considerably.

The general examination was negative. The ear, nose and throat, and naso-pharynz were negative; the blood Nassemenn reaction was negative. The roentsenogram of the sella was reported normal. The vision in the right eye showed ability to count eingers and in the left oye $6 / 200$. Whe pupils were unequal, the right being Isrger than the left, and the resctions rore slow. This was more pronouncod in the rifht eye. There vas a marked ptosis of the right upper lid with a divergent squint of about 20 degrees, patient flatis with the left eye. The extra-ooular movements showed a pawalysis of the left inferior, left aperior oblique, the right external reotus and the levator palpebral. The fundi showed a slight pallor of the dise in the wight eye while the left diso was nomal in appearance. The perimetric fields showed concentrio oontraotion for form in both eyes with prectionlly complete bitemporal hemianopsia for blue color, 
the patient was unable to recognize red on green color. The blind spot in the leit eye was considerably enlarged.

A diagnosis of tumor cerobri vas made from the neurologioal findings. The patient grev progressively worse and died July 10, 1920. Jeoropsy revenled a tumor of the third vontriole invading the base of the brain vith aoute internal hydrocephalus, beginning terminal bronchial pneunonis, and mitral endoonraitis. Case 4342936....ura. O.D.T., aged 40 years, was examined Dec. 6, 1920 baparae of poor vision in both eyes. She had itrat notioed loss of viaion in January, 2920, when in reading she could see the last half of the word before she asw the first half. Vision gradually diminished until she was unable to road. Lbout $20 u r$ fontha ago she had noticed that she could see better out of the inzer corners than put of the outer corners of the eyes; this was more noticeable in the ritht eye. For sbout fifteen or twenty jears she had had infrequent headachos which had inospacitated her for a day or two, but bie had had none recontly. Her gonoral health 1ad been jood and she had had numerous genersl examinations without plnding a defihite causo for her trouble. 11 l her teeth had been renoved. The physioisn who referred her to the Clinic reported "bitemporal hemlanopsis; vision in tho rifht oye, Ability to oount eingers at 10 inches in the nasal lield, vision in the left eye 20/100; Iundus negative. The pationt has mild glyoosuria."

Tho goneral exantuation revealed blood-sugar 0.3.36 por oent and no dispetes. The Wassemann test on the blood and the spinal eluid wero negative; there pere nine Iymphooytes to the ficld. Roentgenograms of the siknll were nogstive. The fietabolio rate was -3 per cent. Vision in the right oye was vecorded, ability to pount fingers 2 feet in the nasal field; vision in the lept eye 6/20. The pupila frexo equal sna reacted somewhat slugbishly. On the exmination of the medis in the fight eye a few floating vitreous opaoities vore noted; the nerve hesd was round, of Eood color, perhaps slightly pale in the temporsi half; in the left eye the media frere olear, the nerve head round, wather pale in the temporal half; with perhaps a light loss of substance. The pallor of the disos waa not sufficiont to be typioal 

tion of the upper outer quadrant in the right eye, losa of vision for all colora it the right eye, and loss of vision for green in the left eye. The neurologio examinf gtion revealed slight weakness of the left fifth nerve, and apparently slight weakhess of the left seventh nerve around the mouth; the deep reflexes were alightly inoreased. A diagnosis of brain tumor near the ohiasm was made, not typical of pituitary tumor. The patient was dismissed Dec. I8 without operetion. 1. Apr. 5, 1921 the patient returned to the Clinio. Examination of the oyea showed vision of the right eye $1 / 30$ nasally, vision of the left $6 / 60$. The fields showed a bitemporal hemianopsia with loss of vision for green color in both eyes.The fundi were not changed. Ileurologic examination at this time did not show any material change in the findings. The spinel fluid was negative. The frome test was positive; there rere two small lymphocytes to the field. The Wasserman reaction o the blood of the husband was negative. Exploration of the ohissmal region seomed to be indiosted.

April 12 the chiasmal refion was explored (Dr. Adson). A tumor tras oxpoad, franular in dppearance, situated betreen the optic peduncles. Apparently it hed broken through its ospsule and extended in the sella from behind and underpeath the base of the brain; it was purplish red and extremely fibrouse Pifty milligrans of radium was buried in the growth for twenty-four hours. The patient's convalescenoe was uncomplioated exoept for restlessness. Tho pathofogists reported endothelioma.

May 5 the eyes vere oxamined. Vialon in the right oye was $6 / 60$, in the fort eyo 5/60. The pupils were equal, the reflexes norms. The fundur of the pight eye was nomal; in the left eye the nervo head was pale without loss of aubstance; othervise it was negative. The fields showed improvoment with return of Vision for all colors, but a persisting bitemporsl hemisnopsia. The neurologio examination at this time did not revenl changes.

The marked pallor of the left nerre head with the slight loss of sub- 
stance and the first Ifeld, whioh ahored the loss of the lower temporsi quadrant with preservation of a seotor of the upper temporsl quadrant, led us to belleve that the tumor in this osse was not of pituitary orifin.

Case 4346907.--ikr. S. W., aged 37 yesrs, was examined Jan. 20, 2921 ohiefly because of sovere hesdaches in the left frontal region which had persisted for Pifteen years; each attsol had lasted for from one to tro hours; the pain had revied from a dull to a very sharp pressing type; it had been worse in the daytined For the past six years he had romited once or twioe during s month without nausea. Five yeara before examination he had had to give up talloring beosuso of trouble with his vision. He had usod glasgos for frelve years with suooess until the last Pive, sinoe when his vision had failed graduslly; Glasses hod not improved it. In 1918 the eyes had revesled a left homonymous homianopsia; sinoe thon the eyea had Gradualy failed, with a persistenoo of headaches with nausca.

The general examination revesled an essential hyportension; the systolic blood-pressure was 220, the disatolic 138. The esr, nose, throst snd naso-pharynx Fere negative; the Wassemann resotion on the blood was negative. Roontgenograms of the head shored the sella turoios to be frestiy onlarged, ifth destruction of the posterior clinoid processes. The metabolic rate vras -17 per oent. Vision in the right eye was $6 / 30$ with correotion, in the left eye $6 / 15$ with correction. The pupils vere equal and resoted nomally. The oomes and media were cleas. The fundi showed pallor of both disos without excsvation; there was no loss of substanoe, and no evidence of provious arelling of the diso. The maoular regions prere negative. The perimetrio fields ohowed a left homonymous hemianopsia. lieurologic examination was practionliy nesstive eroept for a pubio distribution of hsir, feminine in type and slight loss of strengthe Intelligenoe and comoporion were alightly belor normal. A aisgnosis of questionable pituitary tumor was made. A right subtemporal decompression was performed for exploration of the tumor (Dr. Adson). "A purplish gray tumor res found situated underneath the brain stem posterior to the commissure, but the optiosl pedunole and comissure in front Lere peviectiy free and not stretiched. On acoount of the extont and nonition of $10.205 \mathrm{M}$ 
the tumor further surgery ors not sdvisable."

The patient convalesced uneventfully and the round hesled by primary

intention. Postoperative neurologio and ojo indings were the same ss before operation, except that the fields trere slightly more contracted.

Case 4347201.--2. D. T., male aged 46 years, was examined Jan. 22, 1921

beosuse of blindness in both eyes. Pationt noticed a yesr sgo that thore was a grodual failure of vision so that ho was unable to read. His eyos vere examined for glasses but did not improve his vision. A little later he notioed that while driving his car he was unable to see the road very well and he had a few minor acoidents while driving. Gradually the vision deoressed so that he practioally oould not see at al.1. Ie had had no general sumptoms such as hesdache, nausos, or vomiting and his appetite had beon very good. In Ootober 1920 he consultod a physician who told him that he had a tumor of the pituitary gland and advised operation. This was not done and two weeks later his vision returned again so that he was able to drive his car. Since that time he has had frequent attaols of Ioss of vision of two or three weeks duration with a falrly prompt return of Bood vision. For the past three weeks patient has boen unable to sce anything and has been more or less mextally unolear.

The general examination was ossentially nogative. The esr, nose, snd throat, and naso-pharynx were negative; blood Hassormann reaotion was slso negative. Blood sugar. 11 per oent and the roentgonogran of the selle turoion was reported negative. The vision of each eye was bsrely light peroeption, the oyes rere nomally placed, and the pupils were dilated to about 6 m.m. right slightly Iarger than the left, they reacted nowmily to 11 ght. The ooular movementa wore normal and the fundi were negative throughout. The perimetric fields were taken roughly with the ophthalmoscopio light but becauso of the mentsilty of the patient Iindings were unreliable although the pupils responded better and he seened to perooive light in the upper nasal quadrants of esch oye. Ten deys later, while in the hospital, tho patient olesred nentally and was sble to see again. At this tinlf 
the oye oxamination shoved that there was a vinlon o2 $6 / 20$ in the right oye and

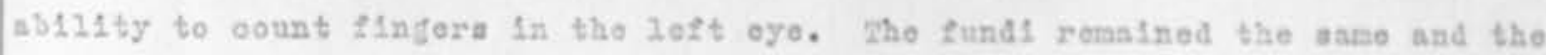

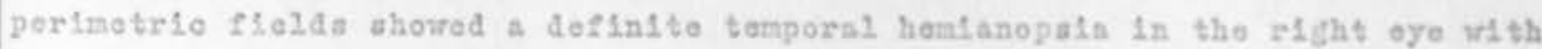

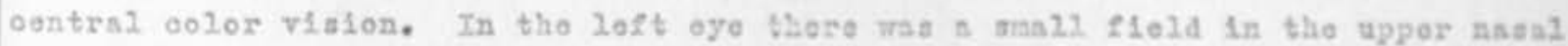
quadrat w1th no oolor poroeption. The pationt did not dealre to have an operstlop and roturned home.

He afain returned for exanination Apr12 5, 1922 and the oxanlastlose were the aame sa those whon f1rat goon Jan. 22, 1921. A diagnoala of tuanor of the oorebri was mado and April 21 tho right parlotal aron iras exposed and a ressatanoo Iraa net. The third vontriolo was punotured through tho oorpua osilosam st a depth of 4 inohes. Flusd was withdram and folloring the operstion pationt was

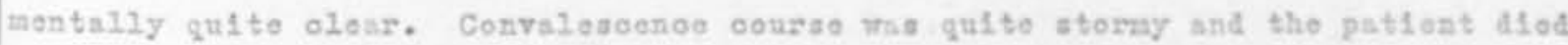
April 17, 1922. Heoropay revenlod s glloms of the third rentriolo.

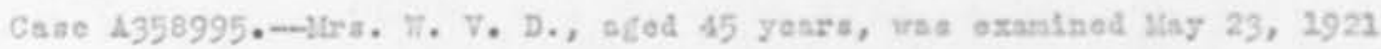

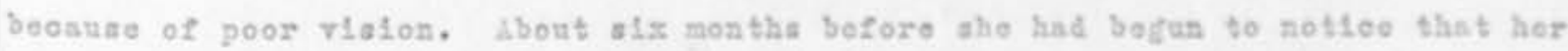
oyenight ras poor; who lad beon unable to noe objoota unill thoy wore slmost in front of her, oapeols2ly on the lest slde. Sho lad hed allght disnlnosa for the

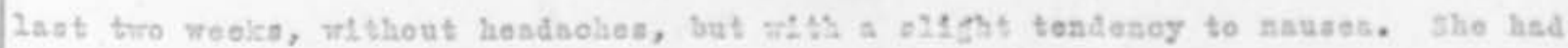
Lelt well Eenersily, and lad not lost wolght. Tro wooks bolore aho had had a spinsl punoture nith reaniting pain aroas the hlpa and baok. The roontgenographio roport ant with the patient was "eroaloz of the selis".

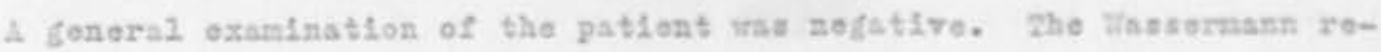
aotion on the blood ras nogative. A roentgenogran revenled the solla to be normal In size and oontour. The blood snd urine rere pegstive. Vialon in the right oro

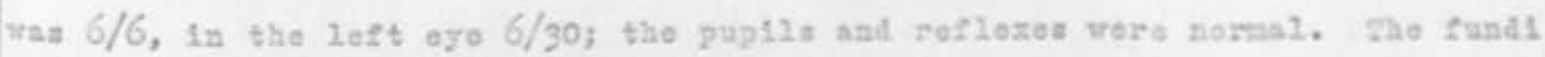
niowred alledt pallor of the nerve hosd whthout lose of anatabe in tha right eye, and mariced pallor of the nervo hosd without losa of abotanoe in the loft eye. The

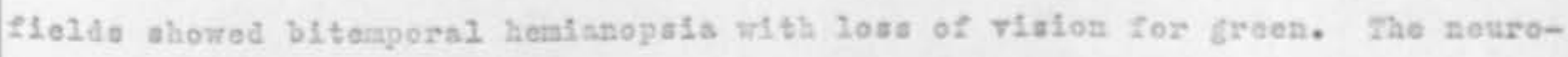

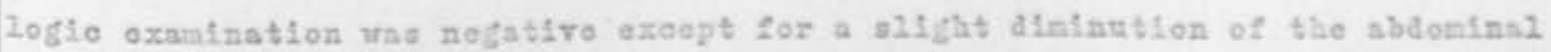


reflexea. A probable pituitary tumor was diagrosed.

May $3 I$ an operation was porformed (Dr. Adaon). "A Granular enospanlated turnor was found resting on the optio commisture, puahing out the right optio peduncle and ooncealing the lest optio podunole. The espeule ras opened, but the tumor could not be enuoleated as ia usually posalble in osses of ordiasy pituitary tumor. Tissue was removed ahich proved to bo extromely ilbrout. The tumor, which was about $5 \mathrm{~cm}$. in dimeter, was coming from tho srachnoid and pressing the Ioft optic pedunole down and outward and the ritht optio peduncle outrard. By osreful dissection the entive tunor was removed and the solla was left undisturbed The pathologist's diagnosia ras pasmona, meningesl tumor.

The patient reacted normaly and was consclous and oheoriul the night alter the operation. At 2 A.lf. she becane unoonacious, the pulse became irrogular. and she threw hor hands srotud wildy. She died audonly the aftornoox of the second day. Weoropsy tras re?usad.

Caso A362271.--Ur. H. C., a eamer sigod 29 yeara, came to the clinio Juno 21, 1922 complaining of loss of vision in the left eye and falling vision in the right eye. The past history was negativo exoopt for an attack of influones in 1918 followed by a good reoovery. In 2927 the pationt had notiood that his vision was poor in the left eye and had oonenlted an ooulist, who gave him glassos vithont any improvoment in the vision. This exarainstion had rovesled lozt viaion in the loft eye and poor riston in the right.

The general examinstion shoued poriaploal infeotion of soven teeth. June 30 the basal metabollo rate was -27 per cent and July $14,-15$ per conte The blood-sugar was 0.12 por cont. Tho roentgenogram of the alla turoios ahowed a moderate enlargenent, but it was othervise nogative. The vision of the right eyo was $6 / 30$; Iingers could bo oounted vith the left eye. There was marked blephrmospasm, with photophobis and alight drooping of the 2ido. The pupils trere aqual and reated normally. The modia trove olear. The fundi ahowed markod almplo atrophy of both norve heads with losa of nerve subatanoe; the martins were diatinot 


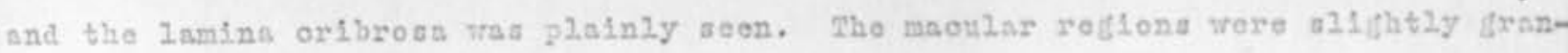
mlex. The perinotrio fields reveslod a right homonymouz homlanopsia. Te bolieved that this was a supragellax grouth, as the fundi wore not fyploal of pitultary grovtha. The nourologic examination was negative oxoopt for the ayo findinga, and a disgnosis of probable pituitary tumor was made.

Aug. 2, 2921 operation ws performed (Dr. Adsoz). "Tho right laterel ventricle was arained and sbout 45 o.c. of oerobrospinsi fluid esanpod. The right frontal lobe was elevsted and the sells expored. The optic ohlasm vas found to bo pushed baclarard and upward by a tumor thloh arose 2 rom the base and fnvolved the sella. It was definitely enospalatod, 4 by 3 on. In diasoter, snd blulah fray. On splitting the espenle betreen the optio poduneles a very pulpy oellular oontent and some blood esosped." Fifty mi121 grams of radiun in a rubber tube var insorted for twonty-four hours. The pathologint's report was collular glloma.

The pattent diod Aug. 3, and neoropay roresled a slioms of the loft temporosphenoidal lobe, coming forvard and Involving tho sells, and hyparplasis of the thymus and Iymphoid tisaues.

Tho marlead simplo optic atroply in this osse, although the othor ophthalmologio findings could have beon of pltultary orifin, lad us to bellove fhle to be sn extrabellar growth.

Case 4365469.-A.D., fomalo, asod 38 yoars, was exantned July 20, 1921 ohiefly beosuse of blindnose fn the right oye and falling rlabon in the loft oyo. The petient notioed that the vioion had been falling for the pant nineteon yasrs. During her first pregnanoy she notioed a swolling of both foet snd lega and alnoo the birth of the child she had feneralised edema aud sho notioed then thst she was unable to soe at atgat but in the dey tine her vialon whs pratiosily nomal. During the noxt three prednancies the troublo reourred. Follouting the fleth prognsnoy sho noticed that hor vision falled so that sho was unable to rosd and has never inproved since. She thintes that the vialon is getting worse slowly and now the vision in tise right ayo is extirely gone. 
The general exnination was essentiu2xy negative. Jur, nose and throat, and naso-pharyax were negatlve; the Tassomam resotion on the blood was also negaf tive. The roentgenogram of the hod shored the sej.2a to bo normal; motabolic rate was -16 per cent. The vision in the right eye was nil, left eyo $1 / 60$. The pupils treve equal and reacted nomally. The fundi showed simple optio atrophy, the reat of the fundi boing negative. The perimetrto flolts showed a temporal hominopsis in the left eye with complete amaurosia in the right eye.

Whe neurological diagnosis wos pituitary tumor, and s right subtemporal deoompression was performed for exploration of the tumor (Dr. Adson). An enospsulsted tumor, hard and fibrous, which covered the optio chisam and peduncles ros exposed. In viert of the extensiveness of the losion only a small speoimen tras retored for diegnosis. The patrologiosl report vas peamona. The patient had an uneventful recotery from her operation and the eyes showed some fraprovoment in rision, the petient boills sble to read $2 / 50$ with the left eye, vision in the right eye vas nil. The flelds talcen ramined prsotiosily the same sa before the operation.

Caso $4372765 .-P$. R., male aged 41 years, wos examined Sept. 21, 1921 cliefly becsuse of poor vision in both eyes. The obangea in vision trere first noticed one jear ago folloulng an attaol of horpes zoster ovor the right thorsx. He consulted various doctors but the viaton was not improved and for the past tro months the vision has failed rapidzy. One mozth ago his noge ma operstad upon (olsewhere) hoping to locato s loous of infoction. The operstive findings woro negative and since then the sight has follod more rapldiy and for the past nonth he has been unable to read.

The general exanination was osseatislly negative exoept for enlarifed septic tonsils. The naso-pherynx was negativo as was the Hasserman resotion on the blood and spinal fluid. The roentgeriogran of the hesd shotred the sells to be normsl, and the right antrum cloudy. The vision in the right oye was noving bijoots at three feet, left eyo $1 / 60$. The extra-ooular movoments more nomal, 
pupils were equal and reacted promptly. There was a sifht pallor of both disos With some blurring of the nasal targins, otherviae the fundi rere normal. The perimetric fields showed concentric contraotion for fom with a bitemporsl sbalut scotomata. In the right eye there was a definite tomporal hemianopsis for formin the leit eye, the patient was unable to reoognize colors and there ras a relative central scotomats. The fields varied from time to time and the color vision varied from a temporal homianopsia in the right eye to a temporal hemianopsia in the left. The perinetrio fields were very chancesile as the absolute bitenporal sootomatas ohanged to a leit homonymous relativo scotomatas in his Isst perimotrio reoora.

The neurological disgnosis was a chissmal lesion. It was thought beat at this time to have the tonsils removed beosuse of sepsis and this wos done Oat. 1, 192I. His convalescence was uneventeul snd he reburned home.

The patient again returned Jan. 5, 1922 and the eyo oxsmination was essentially the same except the vision in the lelt eye had falled so that he whs only able to count lingers. The general and neurological exaninstions were the same as previously geported and a subtemporal oxploration was performed Jan. 30 , 2922, (Dr. Adson), who reported "there was a dark aros just sbove the chissm whioh fras either a round tumor or a mass continuous rith the brain. I think there is no doubt that there is a brain tumor in the region of the unoinato hippooampal syri presenting above the ohiasm. Ndvised radium snd no lurther argery." The patient had az uneventeuI convalescence and stroo tho operation las had a total of $900 \mathrm{ng}$. hours of radiu in the naso-pharynx on two separete ooossions. The vision and fielda have varied somewhat on oach examinstion but have remained prsotiosily the same as bofore operstion.

Case A382942.-B. I., male aged 65 yesrs, was examined Jan. 31,1922 ohiefly beosuse of increasing blindness in both oyes. Por the past fivo yosrs he has noticed that the vision has gradually been 2alling and it vas unable to be lmproved with glasses. He has had no other aymtoms and other tian the failsng 
vision has been perfectly well.

Tho general examination was essentially negative. Jar, nose and throst end naso-pharynx were negative; Wasscmenn resction on the blood was negative. The poentgenogram of the hoad showed the sella to be nomal. The vision in both eyes shored ability to count fingers nasally at one foot. The pupils were equal and Feacted nomally, the ooular movements were nomal. The fundi shomed a marised pallor of both nerve hesds, othemise negstive. The perimetrio fields showed bitemporal hemianopsia.

The neurological diafnosis was chiasmal Losion. The pationt was operated Feb. 14, 1922 (Dr. Adson) and a reddish, granular msss was exposed above the optio chissa extending dom into the sella between the pedunclea. It ras Impossible to see all the tumor. Tissue was removed for psthologioal examinstion whioh was reported endothelioma (psamoma). The patient had an uneventful oonvalescenoe and the postoperative eye examination was the ame as bofore operstion except that there was a small island of vision temporally in the left eye and the pationt was unable to reoognize red and green color in either eye. 
Group 4

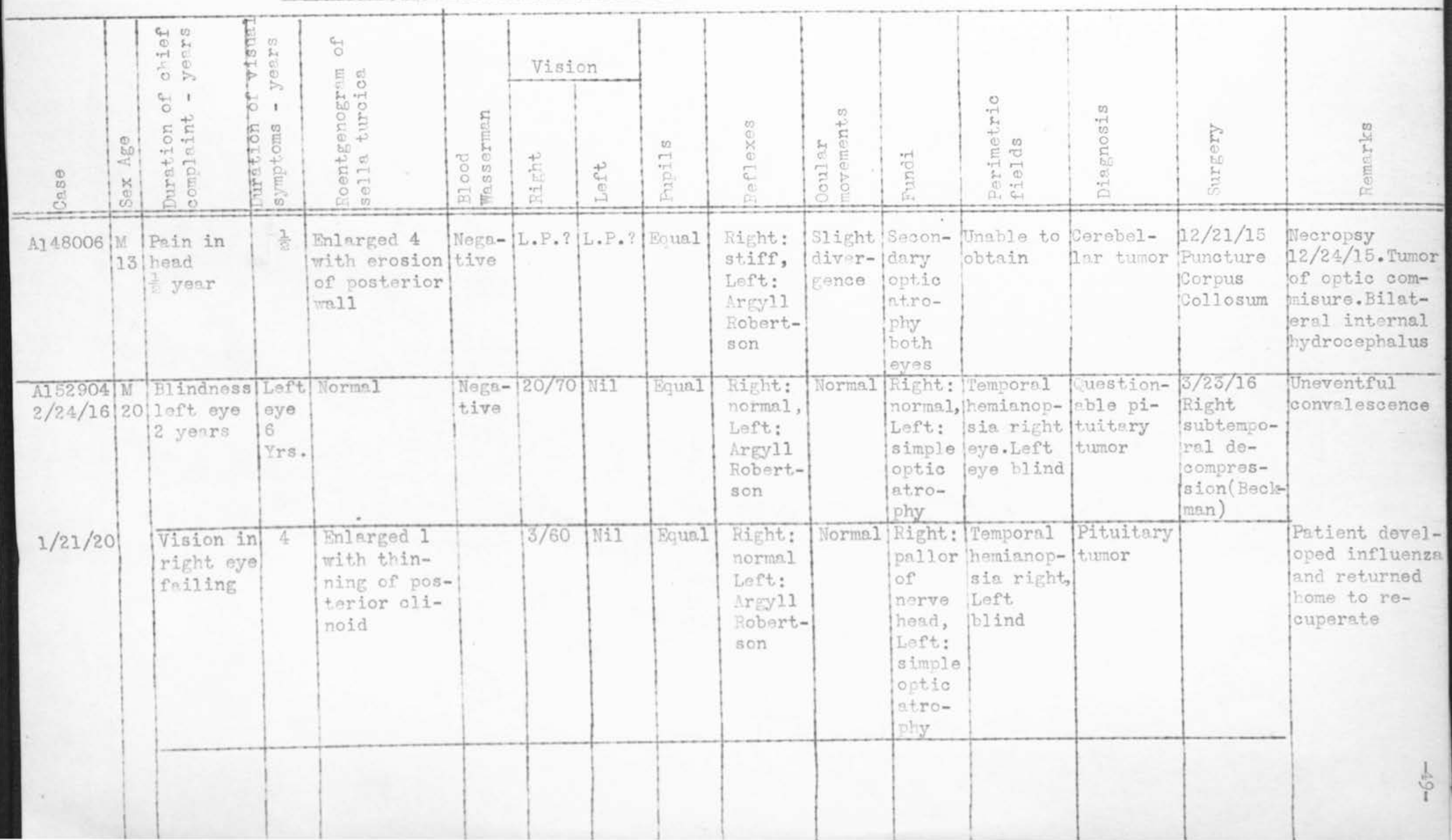




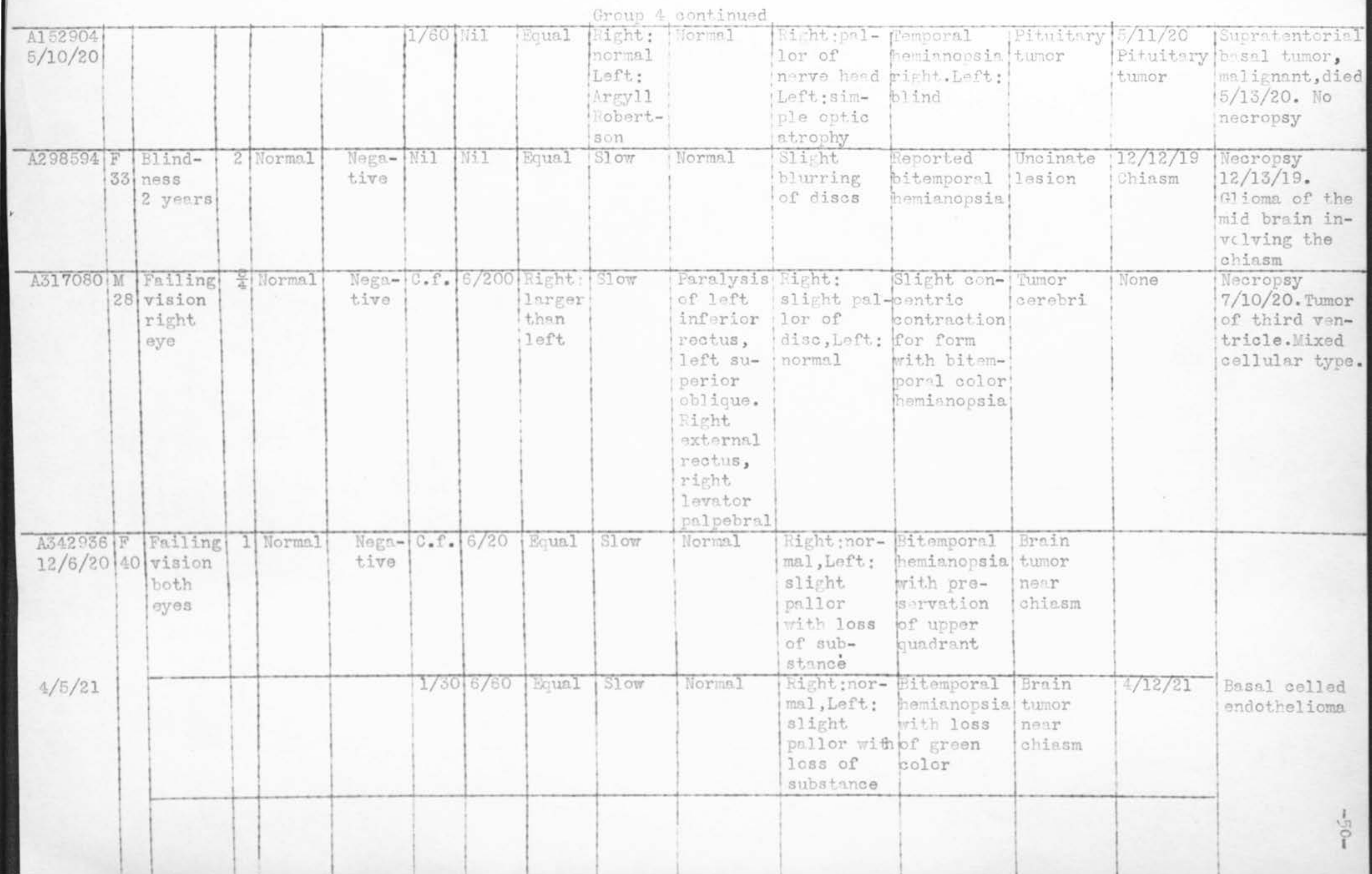




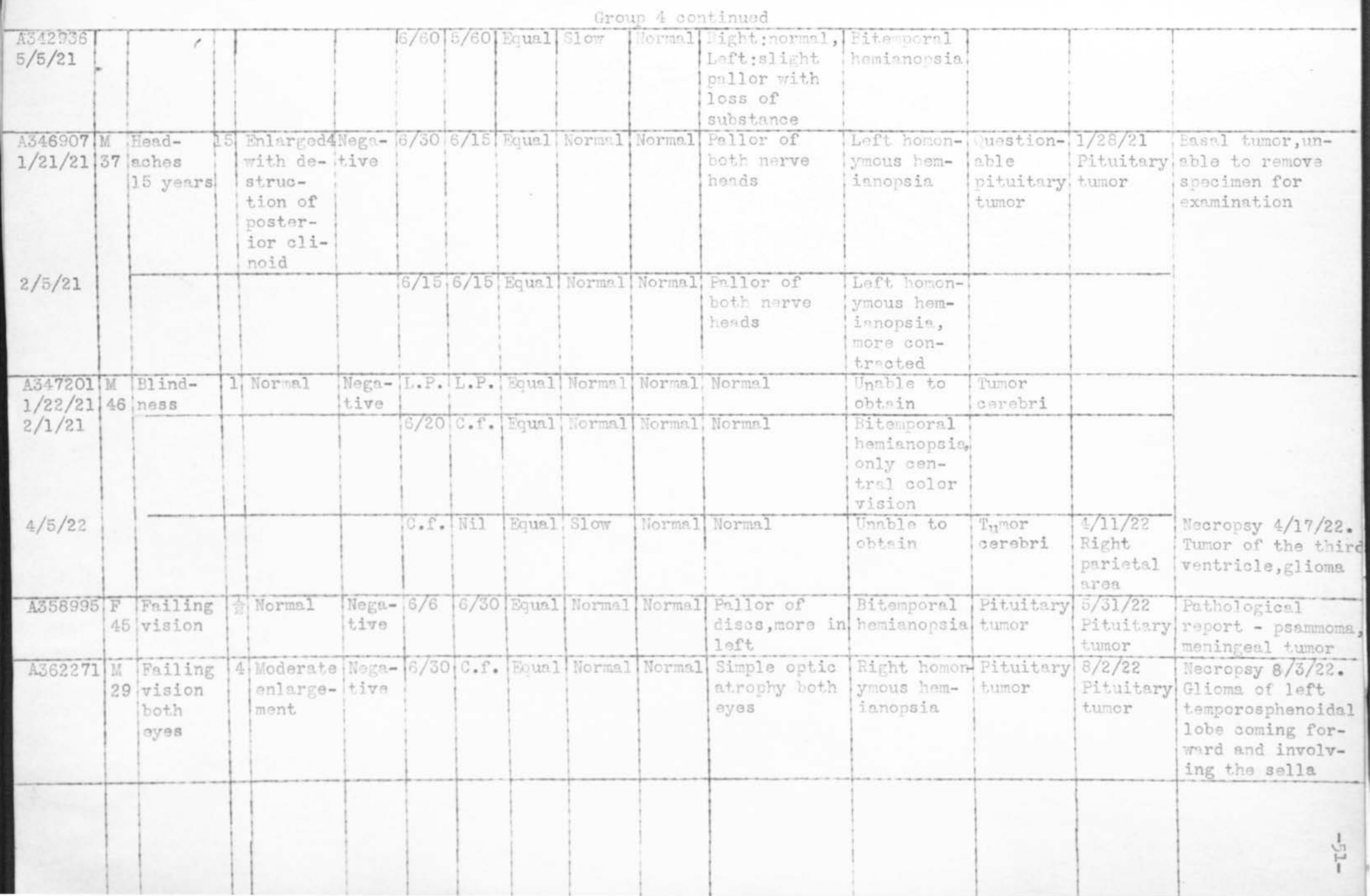




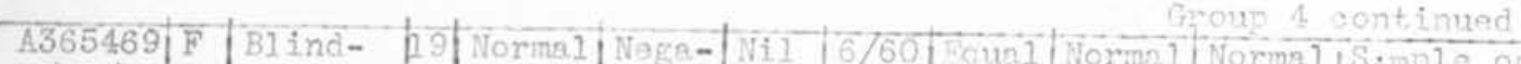

$7 / 28 / 21$ 38 ness

\begin{tabular}{|c|c|c|c|c|c|c|c|c|c|c|c|c|c|}
\hline $\mid 28 / 21$ & $\begin{array}{l}\text { ness } \\
\text { right } \\
\text { eye }\end{array}$ & & tive & & & & & & $\begin{array}{l}\text { atrophy both } \\
\text { yes }\end{array}$ & $\begin{array}{l}\text { imonsia } \\
\text { right aye, } \\
\text { Left blind }\end{array}$ & Thor & $\begin{array}{l}\text { Sibbtanpo- } \\
\text { rol de- } \\
\text { compres- } \\
\text { sion }\end{array}$ & $\begin{array}{l}\text { oncepsulated and } \\
\text { covered optic } \\
\text { chinst and pedunole }\end{array}$ \\
\hline $8 / 25 / 21$ & & & & Nil & 2/60 & Equa 2: & Normal & Normel & \begin{tabular}{|l|} 
Simple optic \\
fatrophy both \\
fyes
\end{tabular} & \begin{tabular}{|l|} 
Tomporal hem- \\
imnosia \\
right eye, \\
Left blind
\end{tabular} & & & \\
\hline \begin{tabular}{l|l}
$A 372765$ & $M$ \\
$9 / 21 / 21$ & 41 \\
&
\end{tabular} & \begin{tabular}{|l|} 
Failing \\
vision \\
both \\
eyes
\end{tabular} & 1 Normi: & $\begin{array}{l}\text { Nega- } \\
\text { tive }\end{array}$ & 15.0. & $1 / 60$ & Equal & Normal & Norma1 & $\begin{array}{l}\text { slicht paI- } \\
\text { lor of } \\
\text { dises with } \\
\text { nessl mar- } \\
\text { gins blurred }\end{array}$ & $\begin{array}{l}\text { Conoentric } \\
\text { contrection } \\
\text { with temporal } \\
\text { scotomate } \\
\text { right eye. } \\
\text { Left temporal } \\
\text { scotomnta } \\
\text { with central } \\
\text { relative } \\
\text { scotomnta }\end{array}$ & $\begin{array}{l}\text { Chiasing } \\
\text { lesion }\end{array}$ & $\begin{array}{l}10 / 1 / 21 \\
\text { Tonsil- } \\
\text { lectomy }\end{array}$ & \\
\hline $1 / 5 / 22$ & & & & c. . . & c.f. & Equan & Normal & Mormal & $\begin{array}{l}\text { Slifent pal- } \\
\text { lor of discs } \\
\text { rith nosal } \\
\text { margins } \\
\text { blurred }\end{array}$ & \begin{tabular}{|l|} 
Conoentric \\
controction \\
With temporal \\
heminnopsia, \\
right eye. \\
Left temporal \\
hemianopia \\
with entral \\
relntive \\
scotomata \\
\end{tabular} & $\begin{array}{l}\text { Chinsmil } \\
\text { lesion }\end{array}$ & \begin{tabular}{|l|}
$1 / 30 / 21$ \\
Subtempo- \\
ral ex- \\
ploration
\end{tabular} & $\begin{array}{l}\text { Dark area ebove the } \\
\text { peduncle in region } \\
\text { of the uncinate and } \\
\text { hippocampel gyrus } \\
\text { pressing on the } \\
\text { ohiesm }\end{array}$ \\
\hline $7 / 13 / 22$ & & & & 1760 & $6 / 10$ & Equa? & Normal & Normal & $\begin{array}{l}\text { Slight pal- } \\
\text { lor of discs } \\
\text { with nosal } \\
\text { mnrgins } \\
\text { blurred }\end{array}$ & \begin{tabular}{|l|} 
Concentric \\
contrsaction \\
With temporal \\
hemianopsia, \\
right gye. \\
Left temporna \\
heminopsia \\
rith centrnl \\
relative \\
scotomata \\
\end{tabular} & & & Frescribed radium \\
\hline & & & & & & & & & & & & & \\
\hline
\end{tabular}



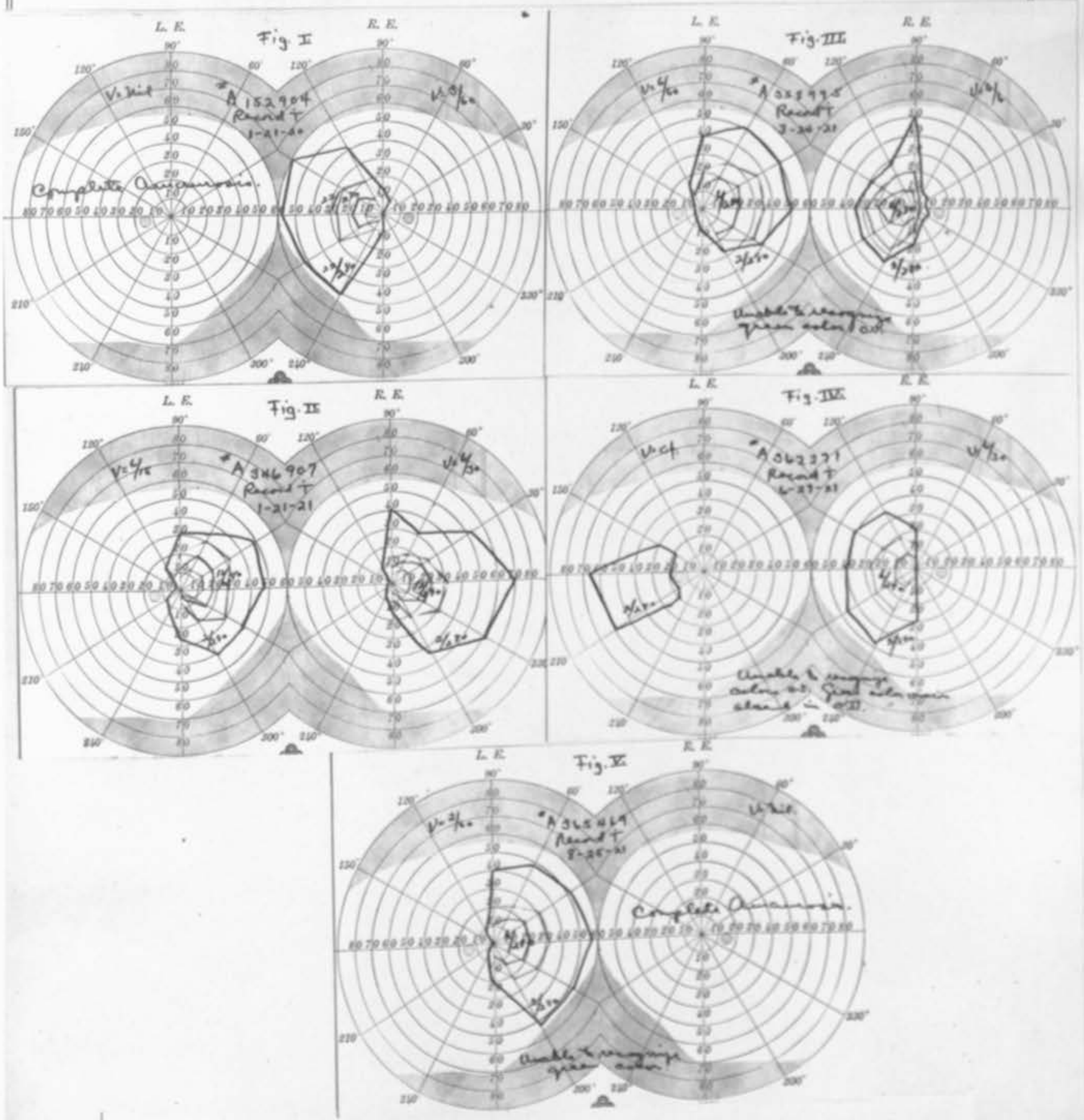

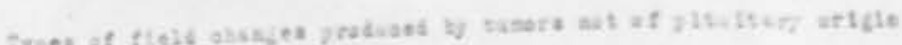

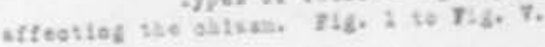



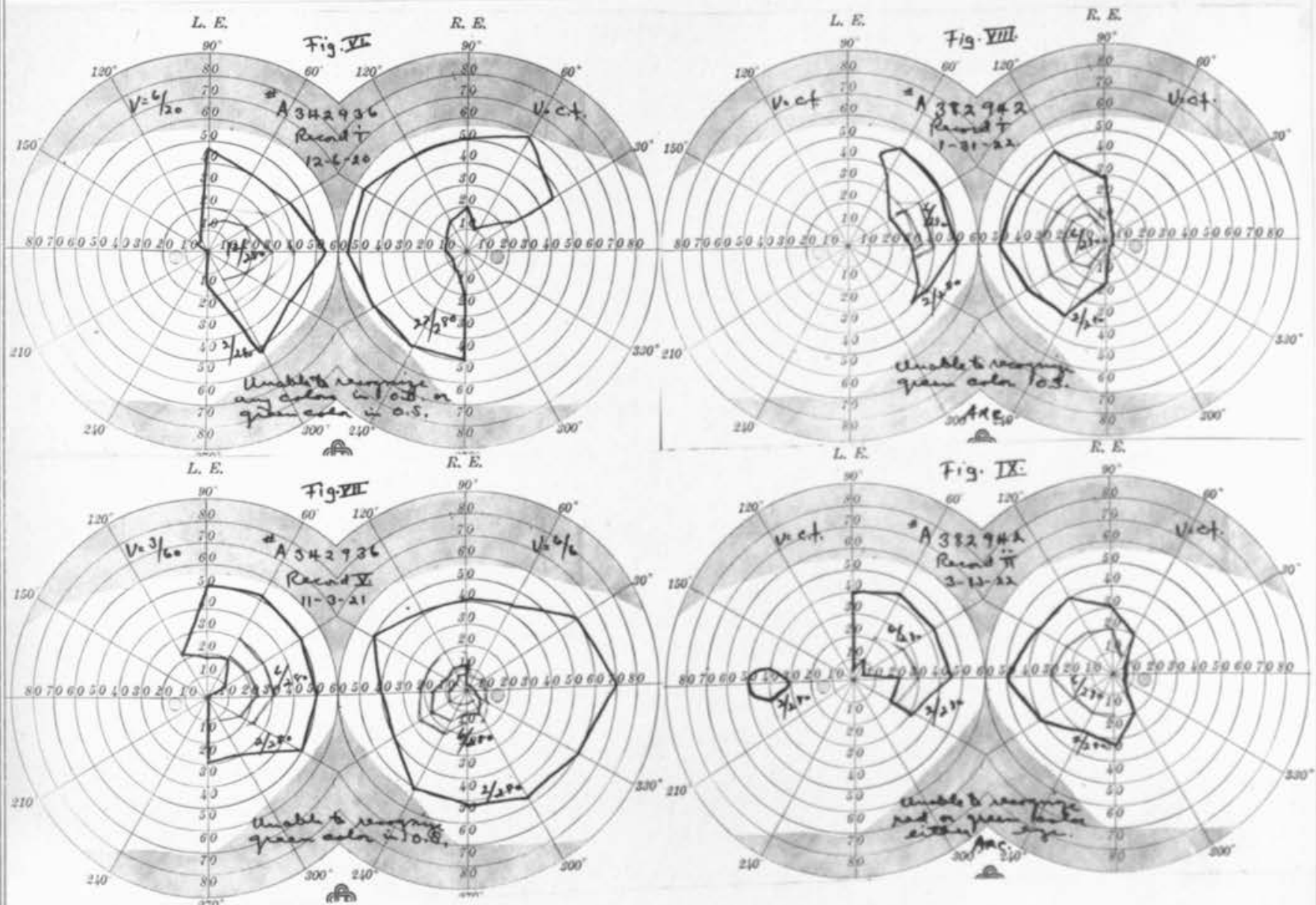

Fig. IX:
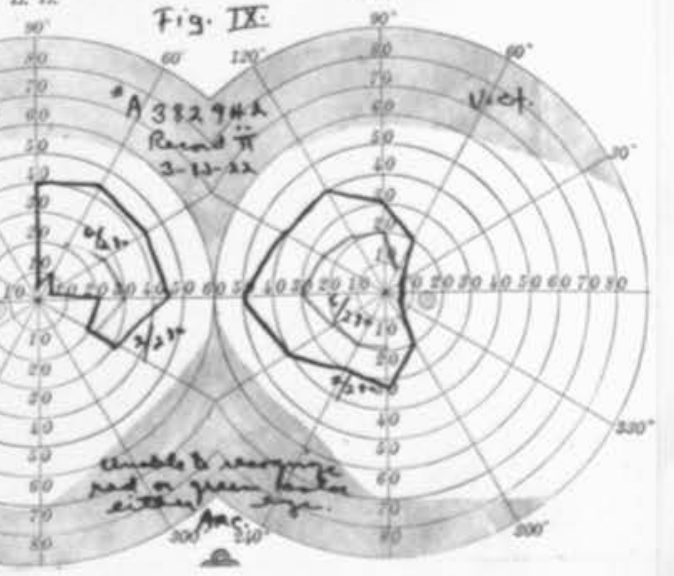

Types of flold ghunges grodueed by tumors not of pitaltary

glede onges prodsoed by

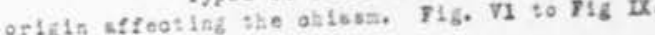




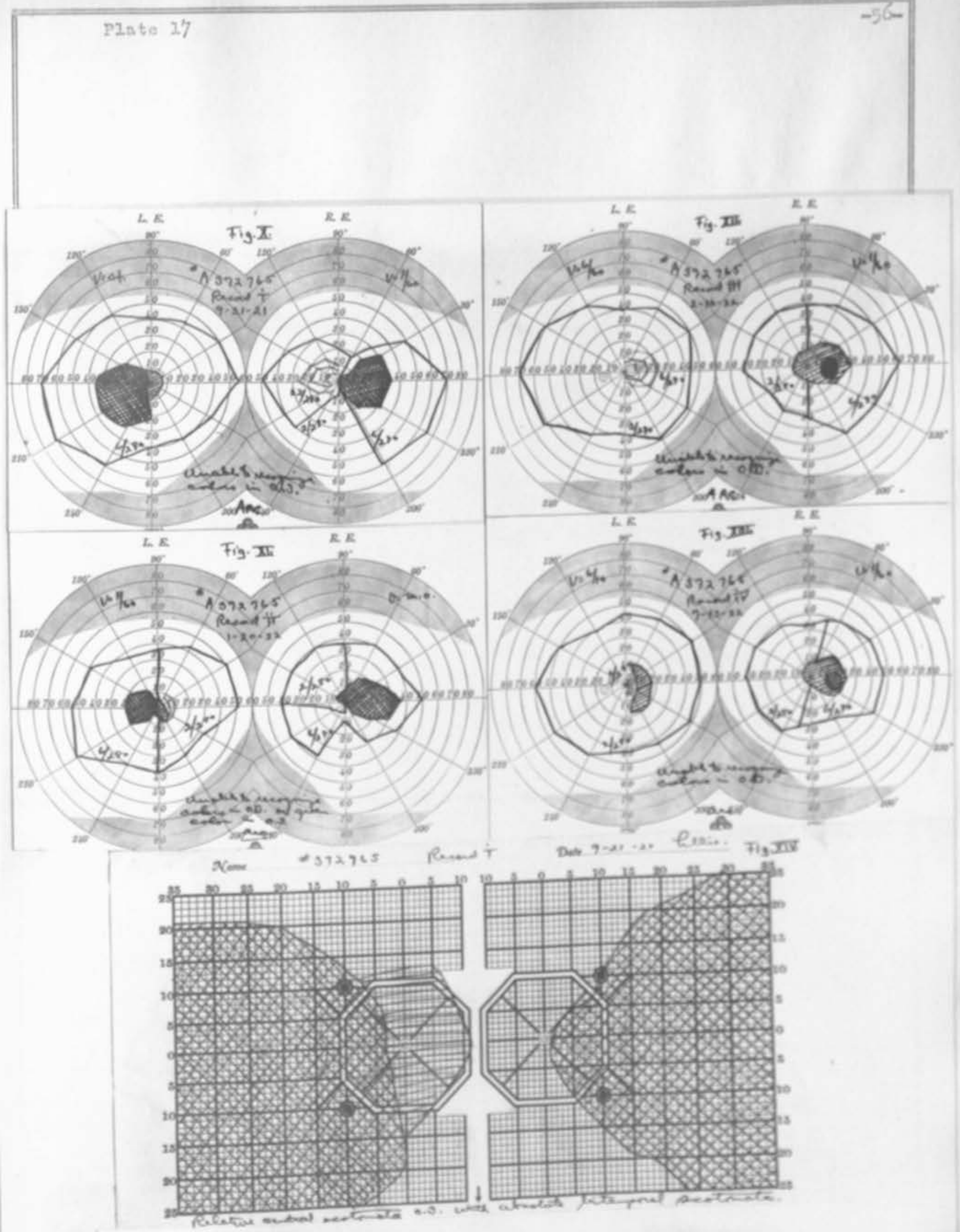

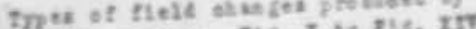

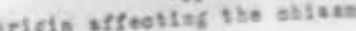



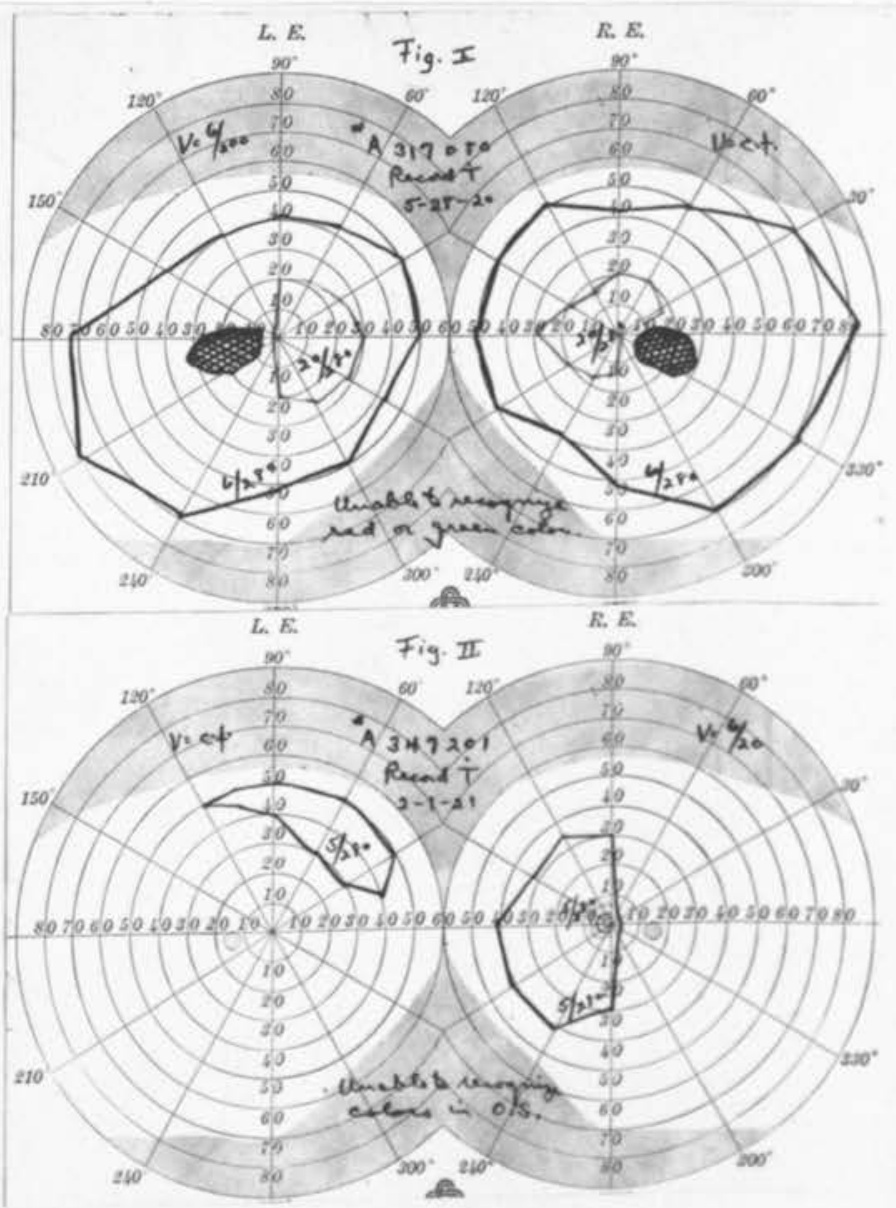

Types of perimetria fle id alinget found In two gosea of

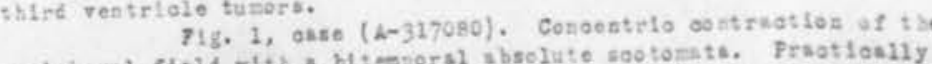
perlpheral fleld wlth a blteporsl absolute sooto

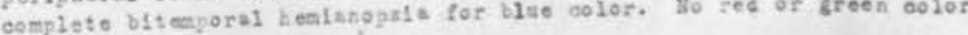

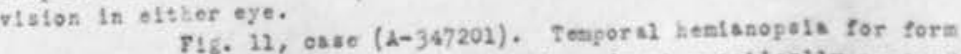

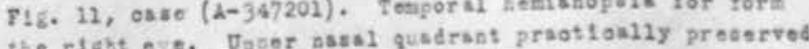
and golor in the rigkt so golor viaton in loft eyo. 


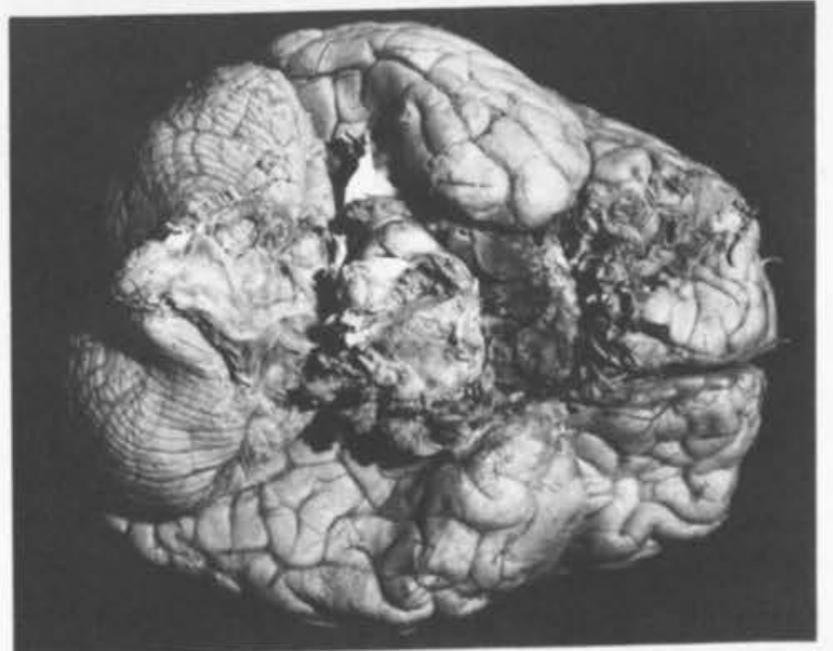

$215 \cdot 1$

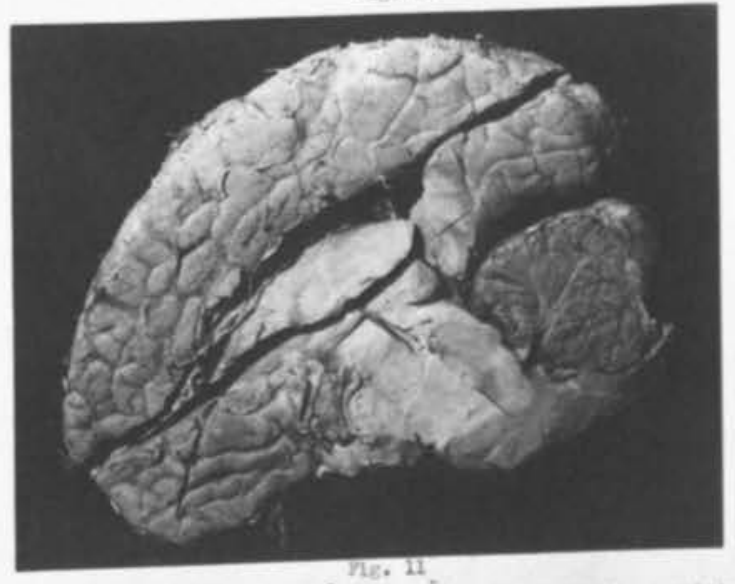

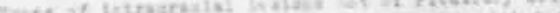

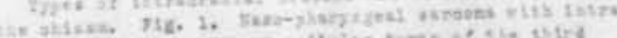

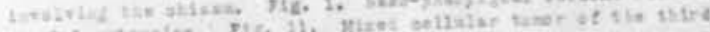

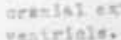


Waso-Plaryngesl Tunors

That the anterior lobe of the pituitary gland taites its origin from the embryonic buocal moosa ss an upgrovth from the primitiva mouth called Rathices pouch is an esteblished fact. It pushes upward through the hypophysis-plaryagesl duct where it meets a protrusion, the infundibulun, eron the fore brain, nnd the pain mass of the pituitary Gland is made up from the epithelial atruoture. Erdheim $^{13}$ in 1904 found a small epithelial body situated in the pharymgeal muooss, onled the Rachendachlypophyse, which was situsted just behind the alae of the romer. He prophesied at that time that a 2002 lasm may be expected to take 1 ta oxigin from such an anloge. Haberield in 1909 confirmed zrdheim's work whon he found a small glandular strand varying from 1 to 7 mo. in length, situated in the pharynGoal muoose just behind the aloe of the romer in fifty-ome hunan subjects of various afses. Crentzieldt in 1909 shored that 35 per oent of fifty-iive cases of pituif tary tumor without soromegaly, at necropsy trere found to be hypophysis-pharyngeal duot tumors.

Cushing in 1912 reported two osses of pituitary tumor which showed a naso-pharyngeal mass. One osso was autopsied and an intor pedunoular tumor origina ting from a congonital rest was found. Jsokson in 1916 nade a study of thirtyeight osses from the litersture in which trenty-six cases had ooular disturbsnos such ss failing vision, optio neuritia and choled diso. Vnfortunately no porimetric field examinations were recorded.

28 . The lislds

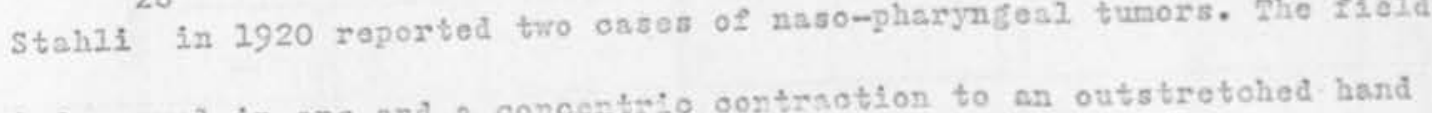
were reported nomsl in one and a conocntrio oontration to an outstretohed hand fras found in one eye in the othor osse. Duffy in 1920 roported three osses of hy-

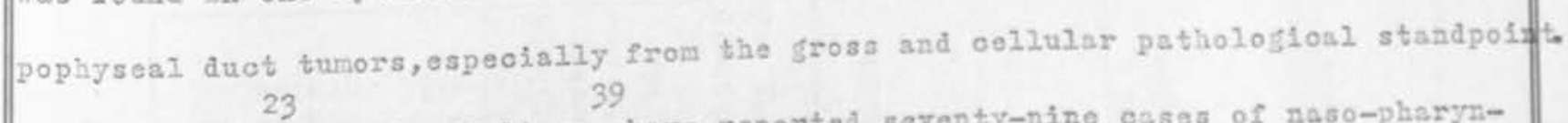
New and also Woltman have reportod seventy-nine cases of naso-pharyngeal tumors, thirty-one of whioh had ooular symptoms. The perimetrio field, however, was recorded in only one osse ( 1206023$)$ of this series. The four cases hore reported show perimetrio pield olanges. Group 5. 


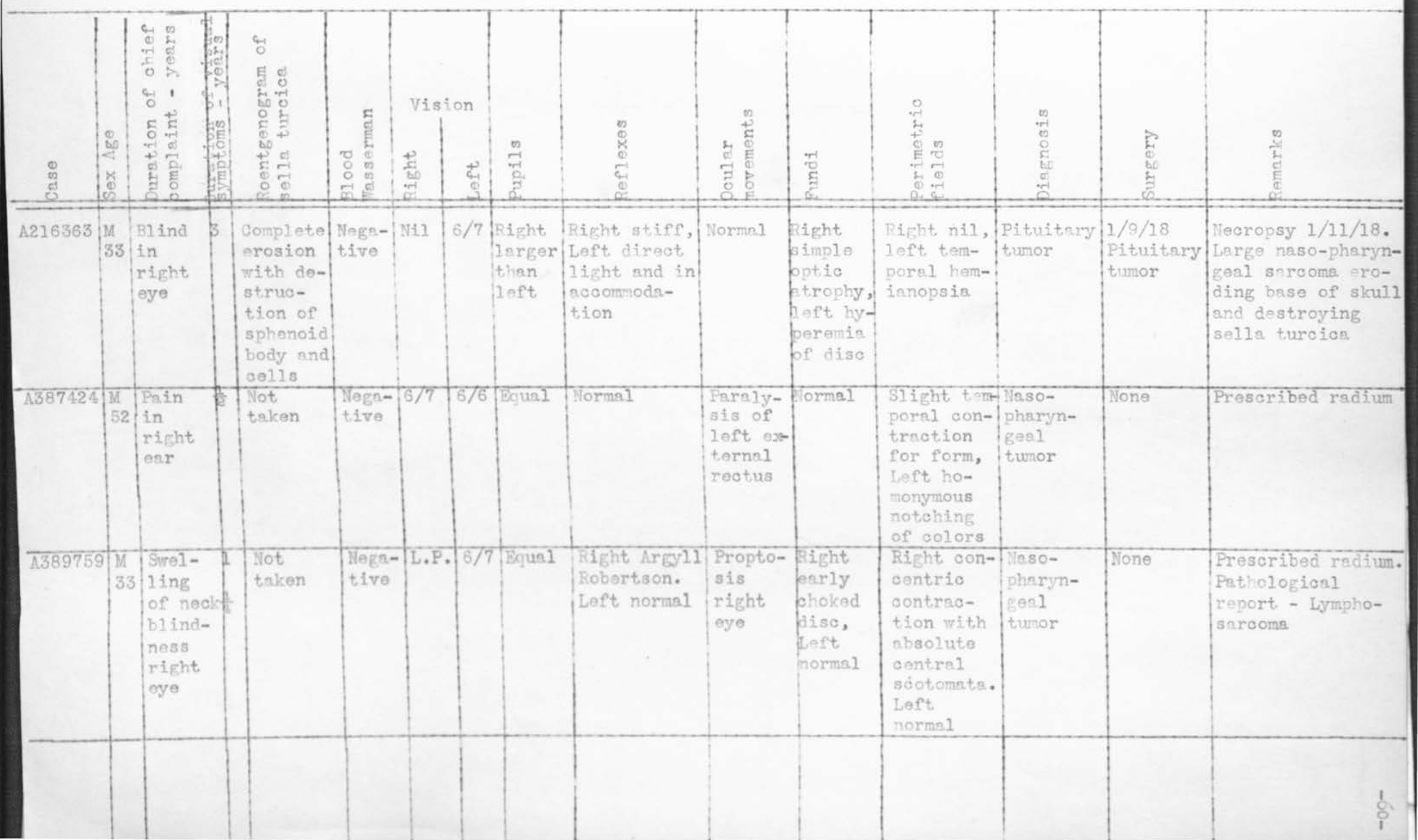


Groun 5 continued

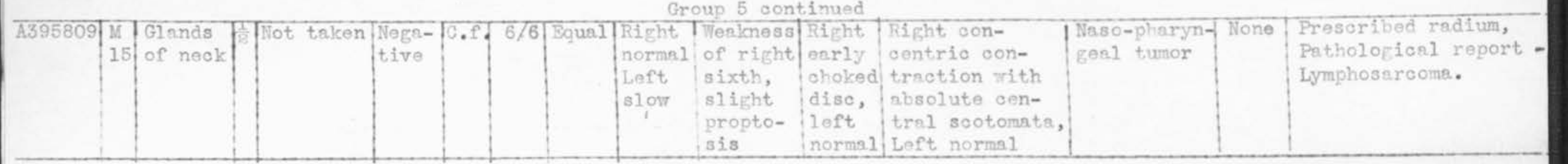


The first oase of this group was extreinely interesting in that the nasopharyax was not examined before operation as it was thought that the condition was an uncomplioated pituitary tumor. Since neoropay of this oase every person suapect ted of having an intraoranis lesion has had a routine naso-pharyngesl examination. Gase $4226363 .-T$. A., male, aged 33 years, tras examined Deo. 11, 1917 because of blindness in the right eyo and headaches. Pationt first notioed throo years ago that the vision in the right eye was faling and in six months he was entirely blind. During these sizmonths he had had some headache snd rertigo and up to one month aso had had no discomiort. Sinoe liov. 20, 1917 pationt noticed severe headache with paineul and atiff neok snd vomiting. During this time he had one attack of unoonsolousness in which he fell to the floor. He consulted a physioian in Chioago who did a lumbar puncture and tho pain vas immediately reileved. A blood and spinal 2luid 13 ssemann was done at that time and roported negative.

The Genersl examination was esaentially negative. Esr, noso and throat exsmination was negative but a naso-pharynx examinstion was not done. Tho blood irassemann examinstion was negative. The roentgenogram of the hesd showrod complete erosion with destruction of the sphenold bone and cells. The vision in the right eye was nil, left eye $6 / 7$. The pupils were unequal, the right being larger then the left, reflezes were stiff in the right eye but the left resoted to direot Iight and in scoomnodation. The ooular moveronts were normal. The fundi showed a simple optio atrophy of the right disc and a slight hyperemis of the left diso, otherwise the fundi were normsl. The perimetrio flelds shored a temporal homianopsia in the left eye and conplete smaurosis in the right eye.

The neurologiosi. diagnosis was pitultary tumor snd the patient was operatod Jan. 9, 1918 (Dr. Ldson). The ohlsomal tunor vas snared out and some of the oystic membrane removed by dissection. The right ollfactory nervo uss saorificed and there was some traume to the lower part of the frontal lobe. The tumor mass fras situsted undernesth the right optio nerve and cormissure but the greater por- 


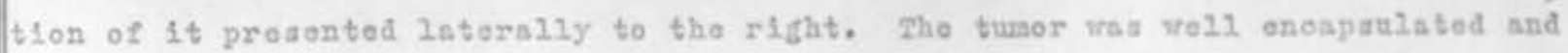
oould be loozoned from the surrounding tlasue dow to the dura oovering the pitultary gland. Pationt had s vory atomy convaloaosoe and died Jen. 11, 2928.

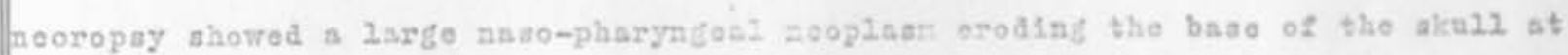
s level of and destroying the wells turolos. The patbolodios r roport was nasopharyngesl sarooms. Fields. 

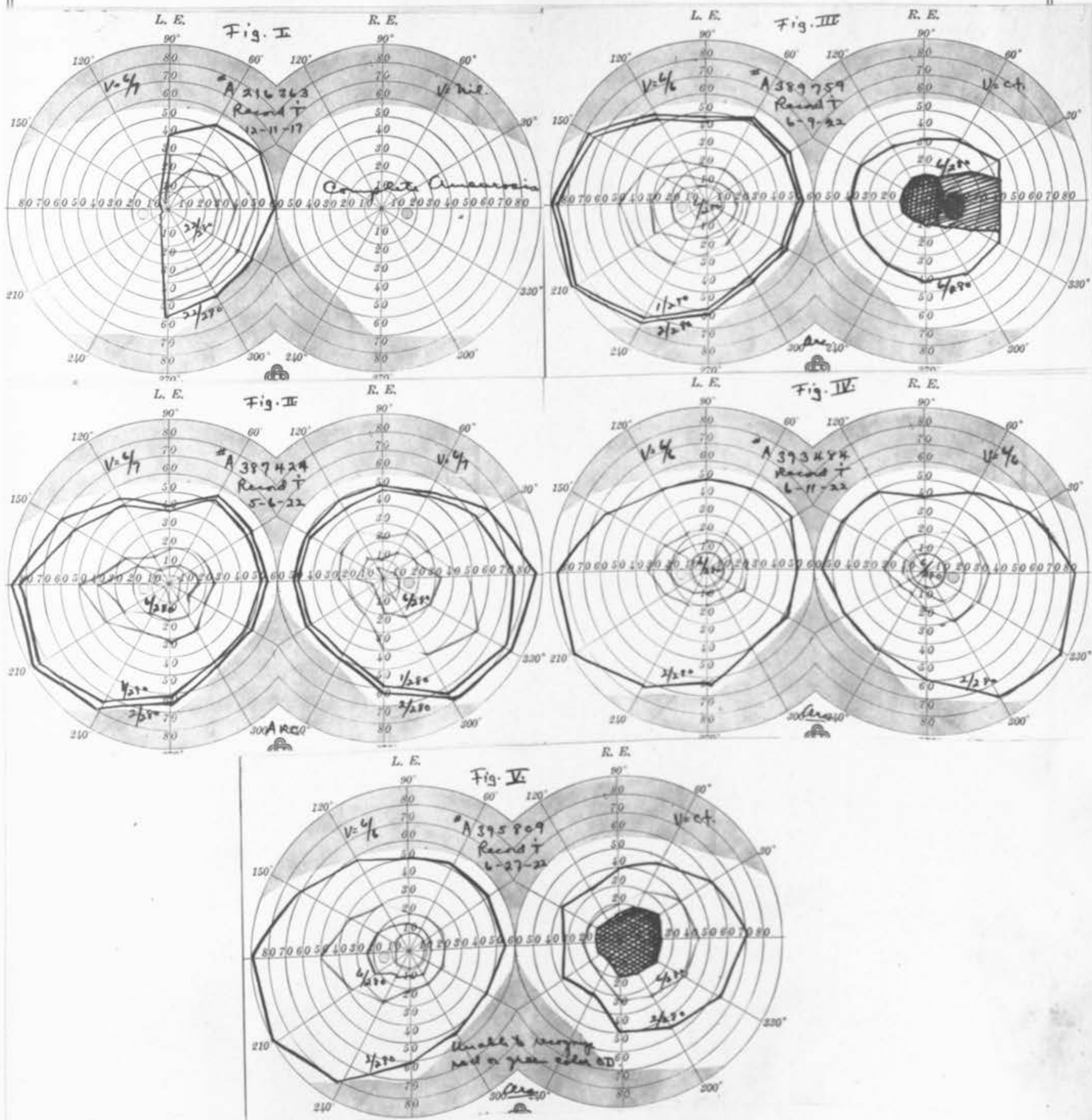

Types of f10ld ghanges produoed by Sisompharyatonl tumors.

718. 1 to 718 . 7 . 

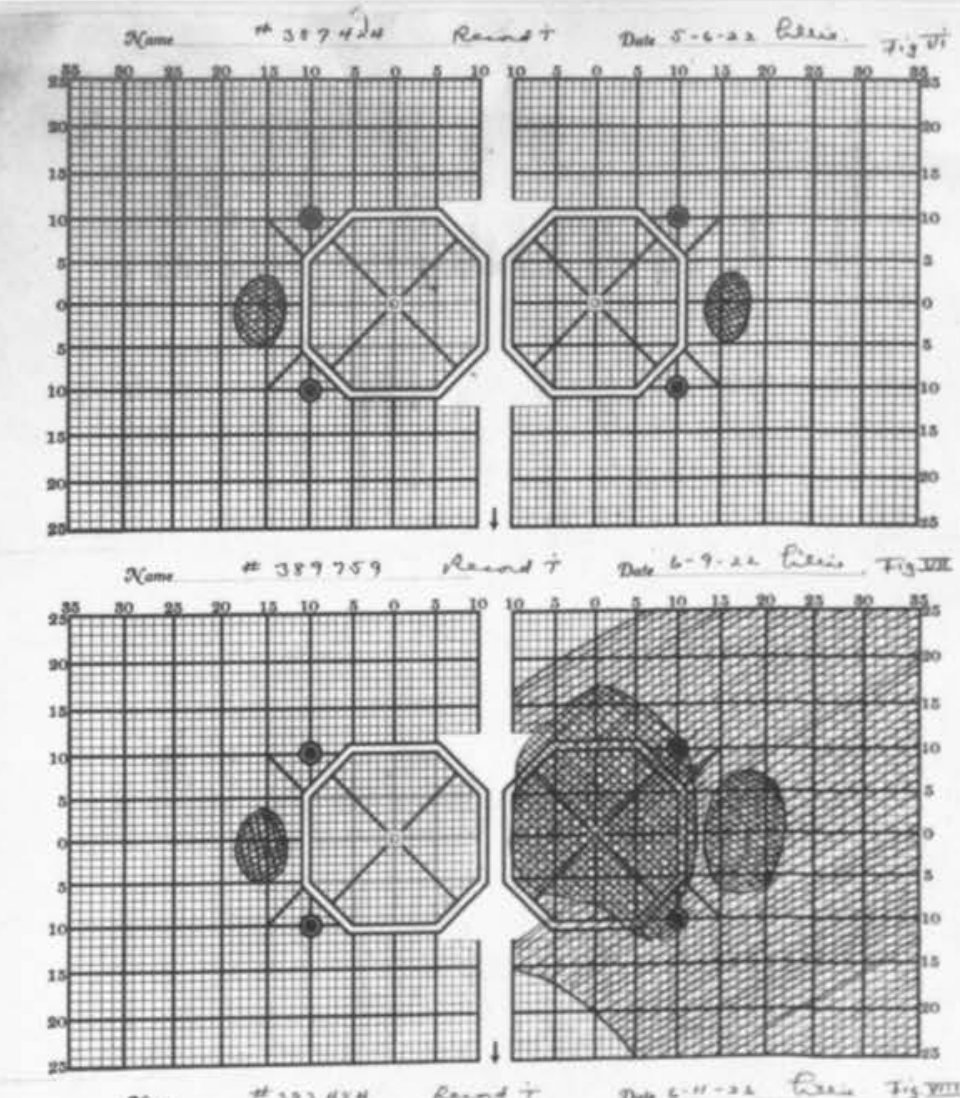
$\mathrm{N}-$

*39 $4 \mathrm{r}$

Rand 7

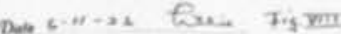

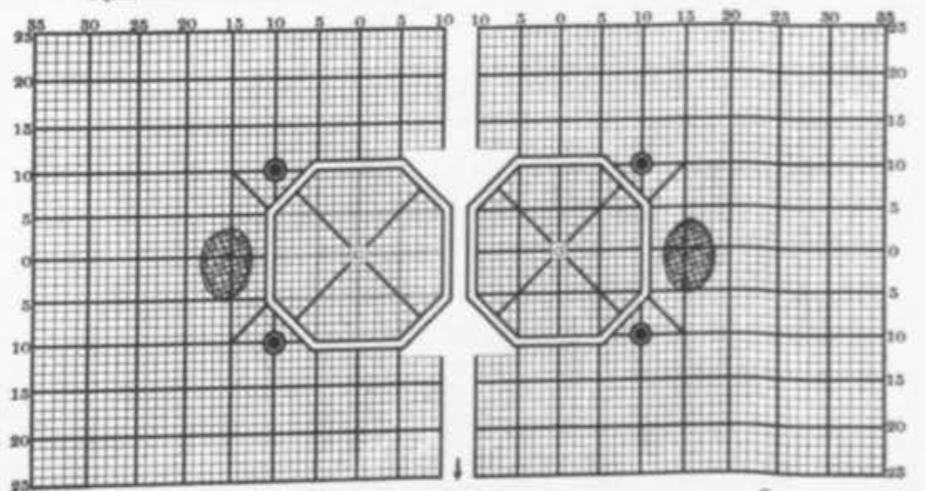

xame

A $3958 \div 7$

Renent

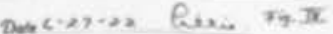

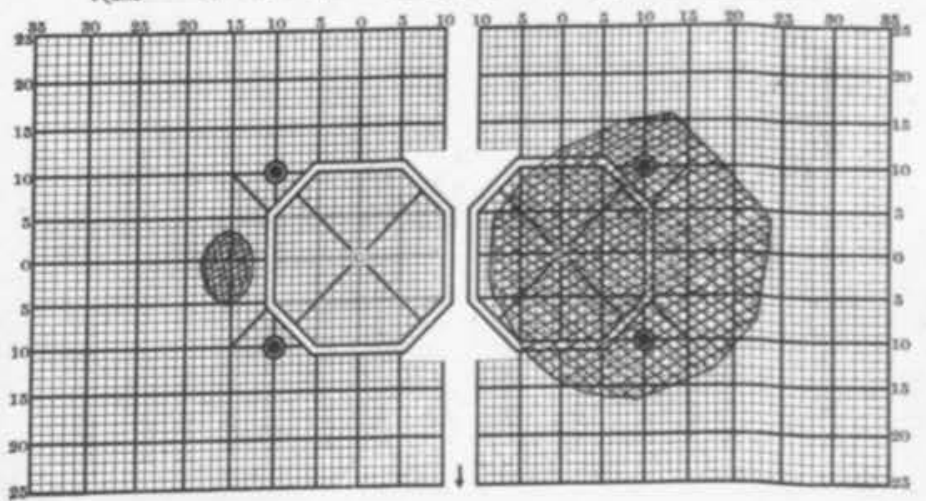




\section{Syphite afteoting the Chisum.}

\section{5}

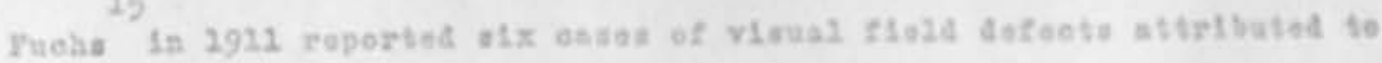

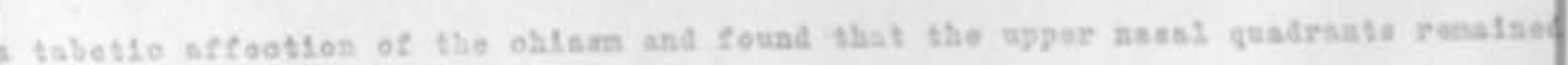
4

foat eroguostly. In 2912 Cuolhing roported one oase of arphtions of us pltultary

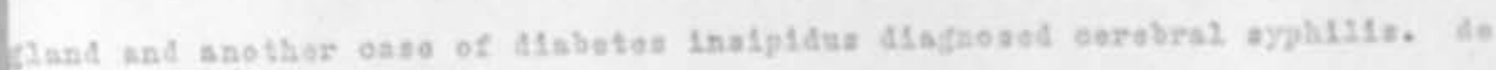
26

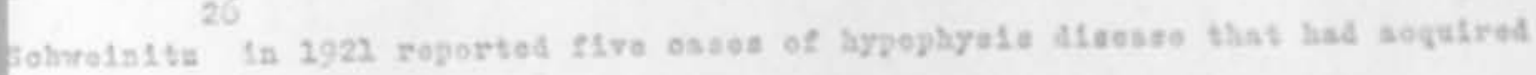

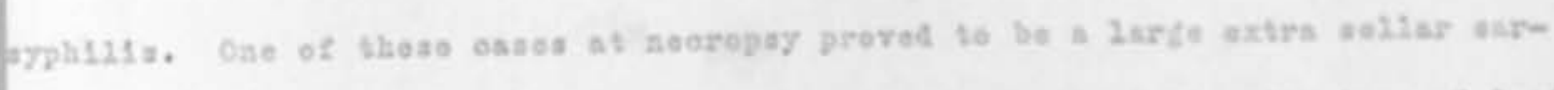

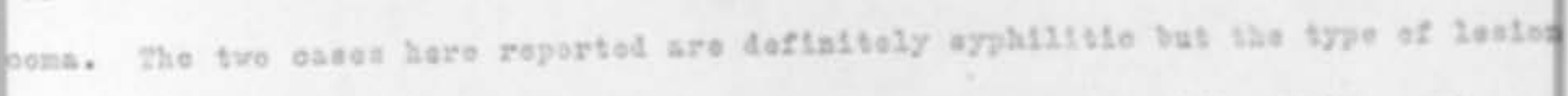

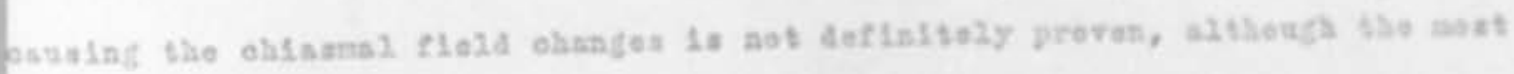

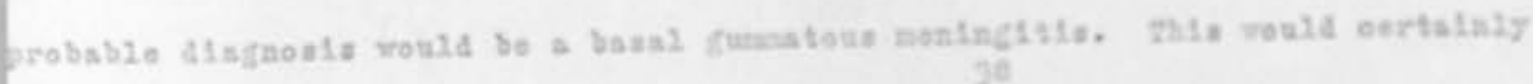

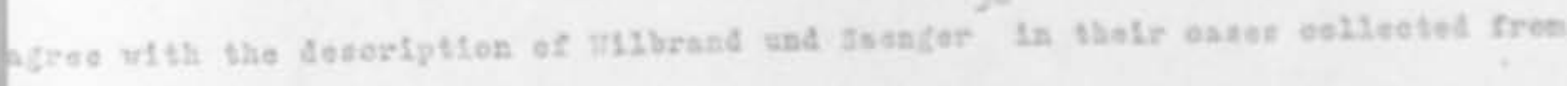

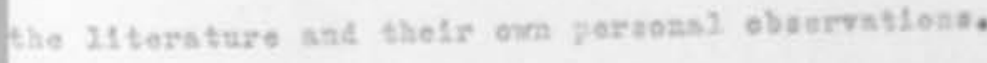


Group 6

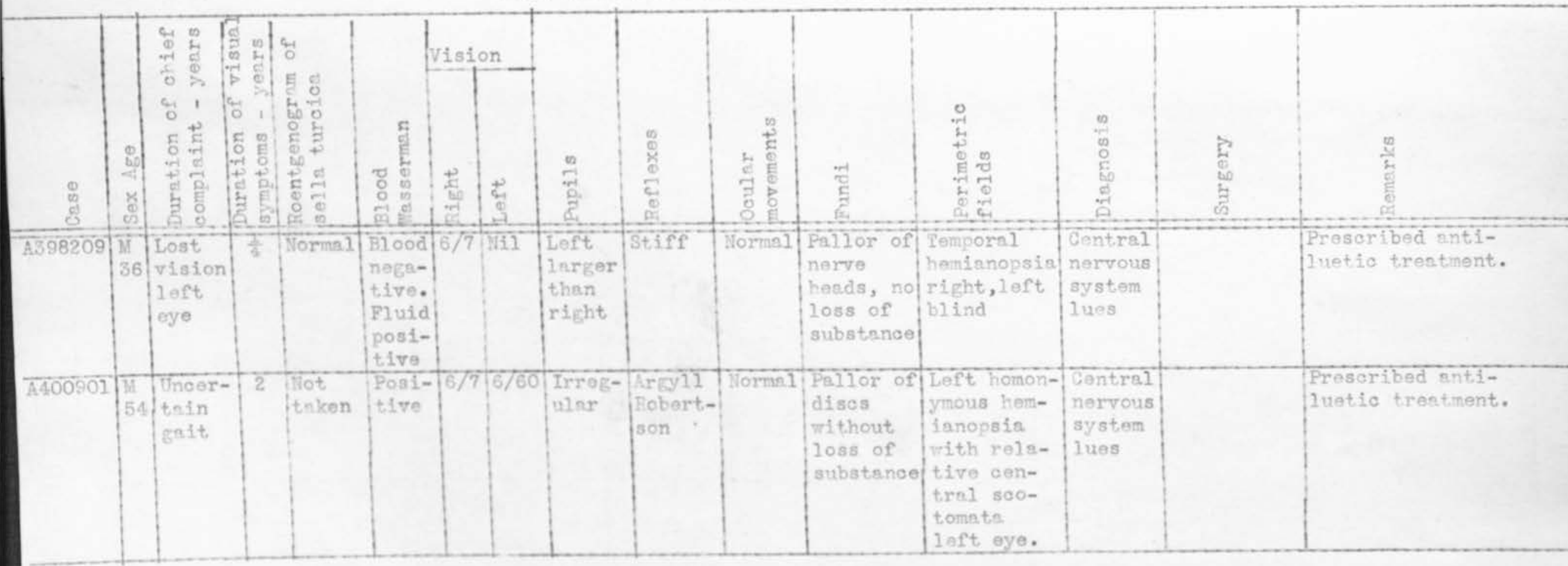




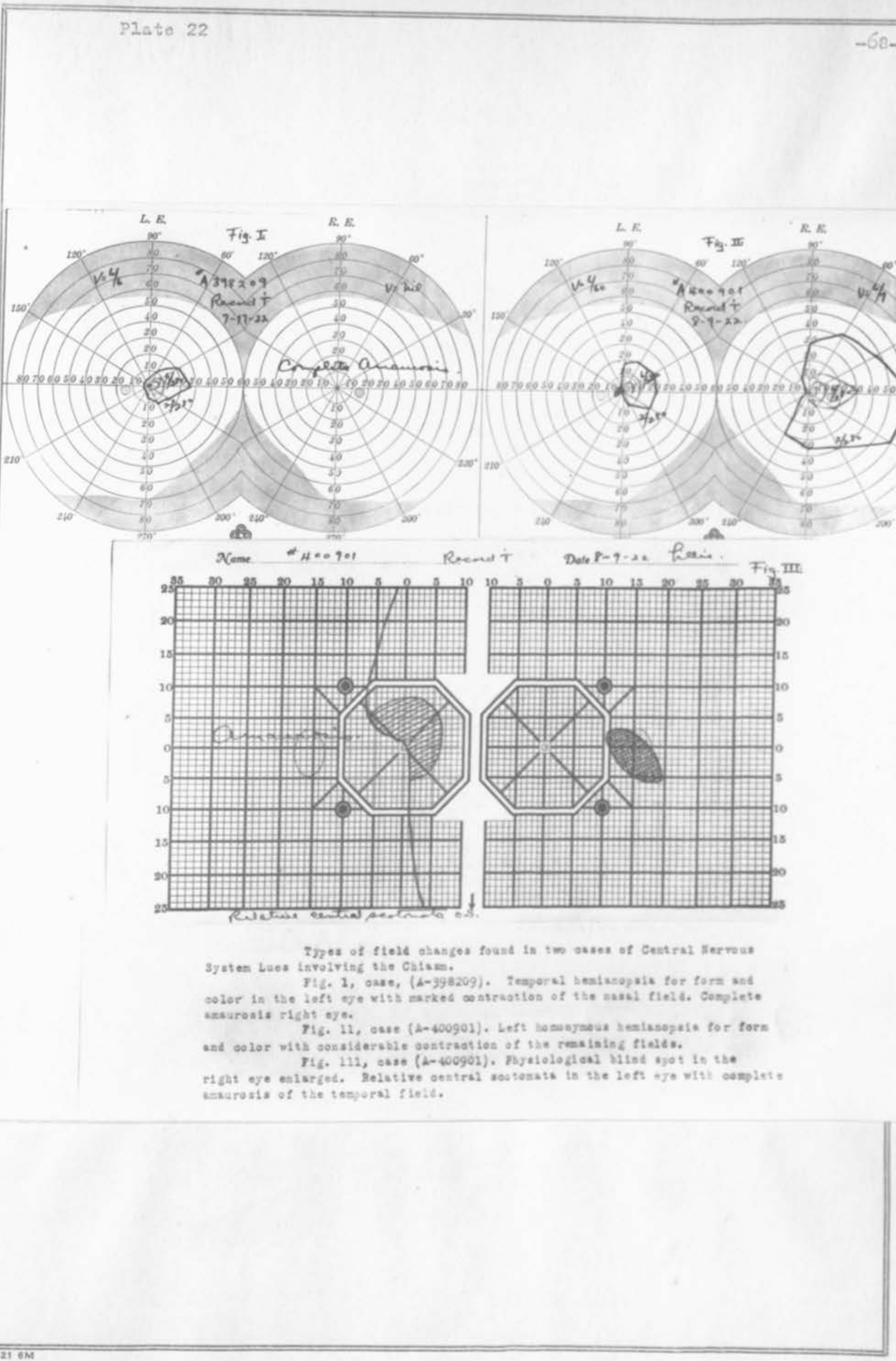


The ophthalmoscopio ohenges osn be readily divided into four maln divisions.

I. Changes in visual souity.

II. Changes of the optio diso.

III. Changes in the perimetrio field.

IV. Ooulo-motor ohanges.

I. Practically every caso, refardiess of the exbot oxuse or loostion of the lesion, came to the clinio because of falling or loss of viaion in ono or both eyes. The duration of the risual ohanges did not rary to any great extent, in the aifferent types of lesion. At least there was not enough alferenoe in the duration of the visusl changes to malse it pathonomonio of any one froup. The losa of Vision is uaully slow if the history oan bo obtained from rellable souroeg, oroop perhaps in the scotomatoug types of field ohanges, which osrly onorosoh upon the macular area. The gradusl loss of vision is probably the resson thy so many of the patients do not consult a plysiolsn until defintte hemianopaia has developed, as usually a temporal quadrant still remsins intact, or lalands of temporal vision are still present. Then the temporal fiolds are lost the chinger urualy have encrosohed upon a portion of the maoular sres so that the visual changes are hoticed by the pationt. The one point which stando out coneiatently ia that the vision does not improve to any appreoibble extent by refraction, even though an exror of one or more diopters, either spieriosl or oylindriosi is prosent. In thing series of csses in whioh there was an opportunity to study the ohangen of vision Defore and after operation, the improvement was alwaye in the osaes in whioh thero ras a normal fundus or pallox of the disos without loss of substance. Helther the Visusl aouity or the fielda in an eye whioh showed a definite simple optio atrophy improved to any appreciable extent following operation.

II. Changes in the optic diso. The typicsi ophthalmoscopic appearance 1

be the disos has been desoribed by Benedict and the pallor without losa of aub- 

stanoe is so frequent a finding that the exprasson ahould be univorasily used instesd of the so-called primary optio atrophy so irequently recorded. 2his 10 in 34

scoord with Walker who conoludes that

(1). "Despito the so-osllod atrophio pallor of the disos in patlenta hoving visual-flold dofecta rosulting from losions in the ehlasmal rogiona, the histologiosl examination of the nerves falla to ghov the oxpected degree of fiber degenerstion uniess the prooess had been of long duration.

(2). "our oases sarvo to 111uatrato the faoto that in the prosonce of chiasmal presaure of tenovn long durstion sisooistod with shsrply out hemianopelas, even when to the ophthalnosoope the nerve shors ths psilor of prosumed strophy, there may be no correaponding shorp delininstion of the areas of atrophy in tho oross-gections of the nerve."

When one atops to oonsider the erequonoy in which the perlmotrio ilelda Improve or return to nomal lollowing the ramovsl of the prosare at the ohisan, It is apparent that the loss of eunotion is puroly a mbloclc" and not due to atrophy Those in whioh the preasure has been of such long durstion ss to produce a simple atrophy of the optio nerves, the perimetrio flolds do not improve follourind oporstion.

In many of the osses herein roported it may be seen from their returned visits and examinstions following operation that those in rhich the disos were reported "pallor without losa of aubatanoe", uaually shor Improvenent in their Vislon and perimetrio flelds whilo those in whloh the disos wars roported minple optio atrophy" gonornily ahov no 1mprovezont elther in vision or porinetrio z1014s following operation. Agsin, in aome oazes, the viausi and perimetrio flold changes are out of proportion in reopect to the appenrsuoe of the disos, aspeolsinf in one oase with noras 2 discs in which the vision wa nil in each oye. II. Changes in the Perimetrio piodas.

A. Techinique.

A12 of the perimetrio flelda reoorded hero have been plottod on the 
Siceel Porineter, the rsdius of whlor is $280 \mathrm{~mm}$. Artiflolal 17lmination has boen used oonstently, the source of aupply originating from 7 - 100 vatt nitrogen bulbs placed in allvered glass refleotors. Theso in turn are plsced tro foot apnrt on a large inverted 0 frame, seven foot in helght and four feet aide. The table on Whioh the peximeter is placed is ona meter forward from tho center of the inverted U standard. In this vay 12lunination is constant as is the diatanoe and the examiner so that any ohanges in the viaual vesulta muat bo on the part of the pation.. I thinl one of the fresteat assots to good osreful perlmetry 1 s to have the pation

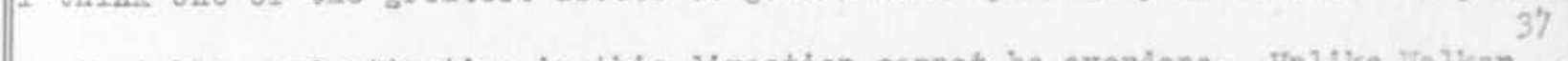
comportable, and attention in this direotion osmot bo overdono. Unlike tralkor, I firmly believe the oolor fields have a frest aisgnostio value in portmetry, and I have been sblo to deteot defeots with oolors when the form flelds with a I ma.

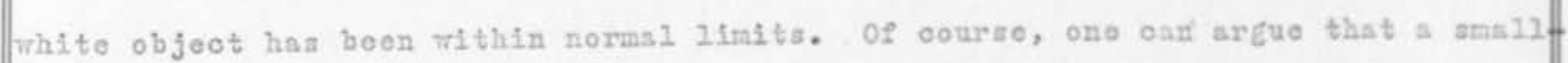
er form object would show the asmo defeot a a the larger oolor object. Thia undoubtedly is true, but why use from flve to seven alfearent form objeots of varyIng sizes on each meridian of the perimeter, when tho same defoct oan be eliofted irith a $6 \mathrm{~mm}$. color object? In some of the 11elds reported in this atuay the oolor fields have been normal for blue and red thillo mariked quadrant dofoot has been found in greon. In this way the grestest number of objeoto a pationt ban to distinguish in one meridian would bo four, and the fatifue olenent is lost narked. ity usual prooeduro is to use a 2 ma. Thlte objoct for form and a 6 am. color objoct, excopt in oases where the vision la too poor for an objoot of this alse. I thon proceed to use the smallest objeot tho patient oun aistingulah.

The central pleld defoots have been oharted on the Lloyd Stereo Campimeter as this instrunent givos binooular 21 xation and also is reliable when the patient has only one good fixing oye. A 1 mm. white objeot la waed routinely with this instrument. All thea plelde have been vith artilloial ilght, the atandard lamp being used as manueaotured by the makers of the instrunent.

B. Field derects. Walker and Cushing in discussing the meohaniam of Chiamal hemianopsis 
think thet Pressure and Treotion are the ohiol laotory, but the sootorats snd 1 ale of temporal. vision may be the result of hypersenaltiveness or poasibly toxio edetatous action or both.

$$
31
$$

Praquair thinks that Pressure and Traction sre not enough to explain the Lield defoots, but that Loosl Intoxiostion at the Chissm seoondary to the tumor or disease offerg a better axplanation for the defeots. From his obsorvations he gives the following conclustons:

1. The perimetric defoots in bitemporal hemienopsis follor a typioal or normal course of development. Commenoing in the uppor-outer qusdrant tho field $1 \mathrm{~s}$ involved in a circular manner, the $20 s \mathrm{~s}$ proceeding olookwise in the wight $2102 \mathrm{~d}$ and counter-clockwise in the left, so that the upper nasal quadrant ramains longeaf. This is the typical oourse and ooours in the majority of oases, but, naturally, not in al1.

2. The central defect or sootoms bohaves in tho amo way, dovelopings like a 1ittie field within s ficld.

3. This type of lield defoot is due to Intorforenoe with the ohisani libres, but 18 Isrgely independent of the exaot nature of the ultimate cause; $1 t$ oocurs in bitemporal hombupsias from a variety of osuses.

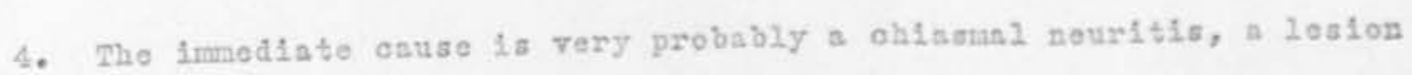
oomparable to that whioh, acting in the optic nerve, produoes the symptoms of retrobulbar neurtis.

5. The oause of thia ohisamsi nouritis ia not dofinitoly knotr. In s21 probsbility it is sot up in aome way by prossure in many ossea. The sooss to the chissmsl libros of irritating toxic subatinoes derived fron the esusn 1 lesion msy be the oause; snd the preanoo of these aubstanoea may in sono essos indireotly srise from prossure. In some casos the ohlamb may directly participato in an inflamatory process. The velstion of the lneunalbulum to the ohisam is vory probably of importance.

6. In tumor cascos, and probably in some osses without tumor, moohanios 
bressure effeots 3 so sot, mainly in the later atsges whon the twor has reached $\mathrm{B}$ folutively larse size.

7. In the later stafoa the normal type of progreas of the fiald changea hay be "swamped" by pressure effects and greatly sltored.

8. These observationa provide evidenoe from the olinios $n$ ide in eupport of the looped arrangonent of the fibrea in the chlaans.

9. They also Indioste that the papilio-macular bundle forma a 11 ttlo chissma within a chisoma and that its fibrea are almilarly arranged.

The perimetrio field defoots found in these froups of osses, osn be classified as followa:

1. Bitomporsi Henlanopsis, partial or complete.

2. Homonymous Hemianopsia, partial or complete.

3. Temporal Hemianopsia in one eye, blind in the othor.

4. Quadrant defects, one or both eyes.

5. Scotomatous ileld doleots.

6. Hormsi Fields.

(2) Thirty-two of the cases of all sroups thoved a bitamporsi homianopul th either partial or oomplete. The hanianopals variod from oolor defeot in one or both eyes, with on early enlargement of the physlologloal blind apot, to more definite hemianopio color and forn defoots. Mlmost all lanom types of defeots rero found, and some ossea shored is marked raristion in the ilelda on frequent exaniastions. In nosrly sll the osses in whioh the blind epot wss ohsrtod, an onlartonen fras found. Somo of the plelds rore withla nomal 11mita, ozoopt for alfght quadFant defeots in the greon oolor flelds.

(2) Seven of the onses showed an homonymous typo of hominnopela, efther partial or complote, varying eros deflntte hononymous hemsanopala for lorm and bolors, to a homonymour defect for oxly one color. These defeots sla ahom oonsiderable varistion on rapested exaninatione.

(3) Ten of the osas showed tomporal hemianopais in ono oye, and oomplotd 
mouroaia in the other. Varying dogroes of oontraotlon of the form snd color fleld forefound, and in acine a loas of one or nors oolor flalda.

(4) Four of the ostes ahowod qusdrsnt deloots in one ox both eyes, Thene farlod from amali defeots of one or more oolora to a doflnito guadrant defeot for form snd oolors. Uaun $12 y$ the onlorsoment of the phyalologlos 1 blind spot enorosohdt fin the fleld of the oolor defoote

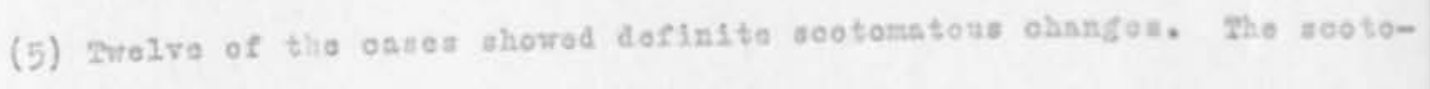
hota are uausliy oontinuous mith tho phyalologlosl silnd apot, or if the prooese As beor of long durstion, tho quadrant or teiapors loas of rialon la oontsunous

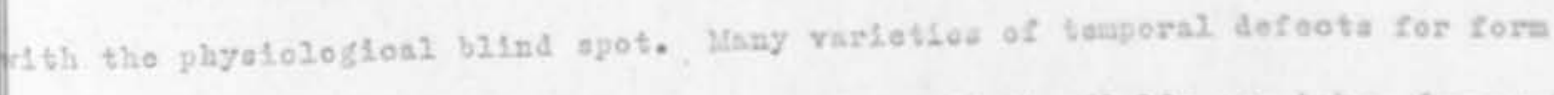
And color ncoompaniod the scotorstous changea. If the thelds bre takes frequantiy, the temporal return of vislon tuanliy procedos the shrimiclit of the soototants. Mhor the blind epots are anrefuliy ohartad on tha liogd's storeo Gamplaetar thoy sro Found to be onlargad esrly in the courno of the Alsosse, and the tomporal aootomats fave almays beon oontinuous with tho b21nd apots. Alzo in the 21 elda in whioh

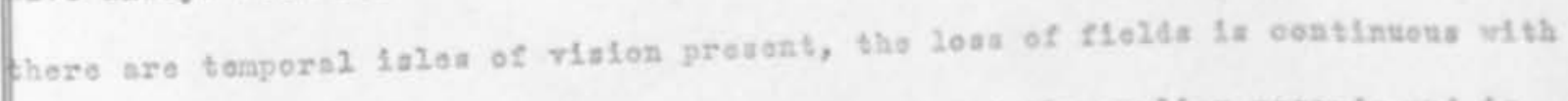
the blind apota. This hsz not boon found is aone of the aarisor reoorda athe la frobsbly duo to faulty teohnique. The reverae slao sooms to ba truo, in that in

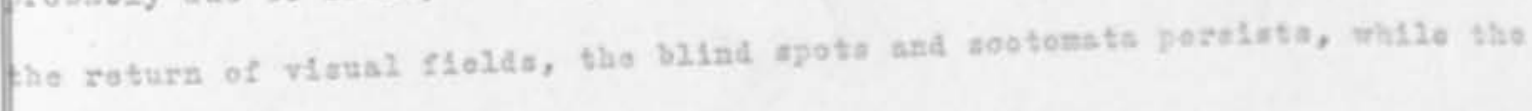
form lielda return nore rspidiy.

(6) Four of the ostoa shoured normal. pertmetrio flelan both tor form and polors. The blind spota were also of norms atse.

IV. The ooular =0tor ehangea.

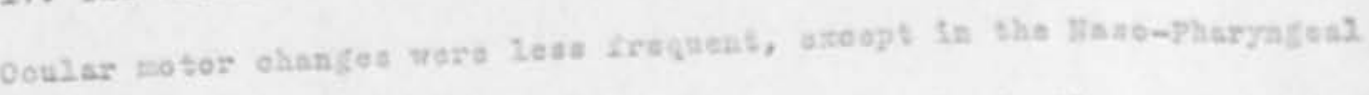

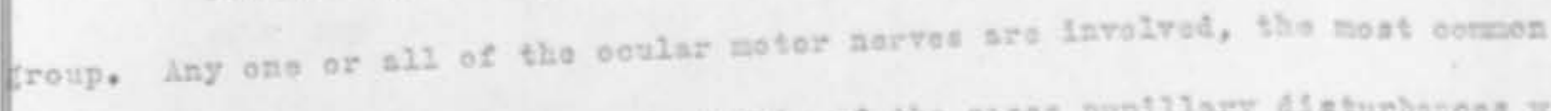

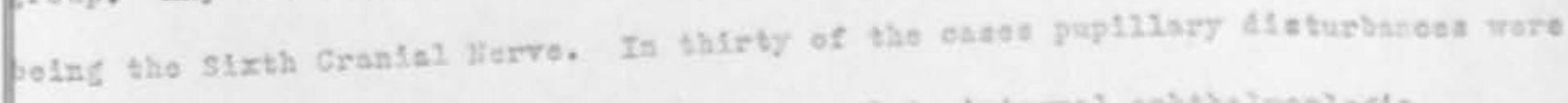

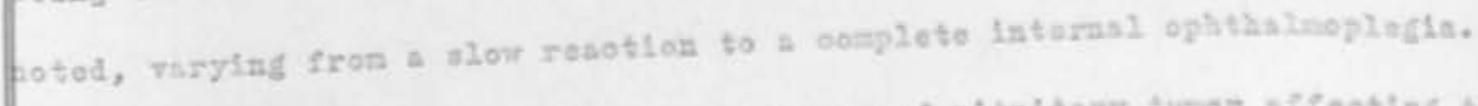

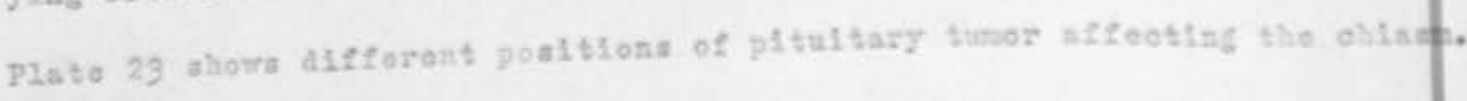

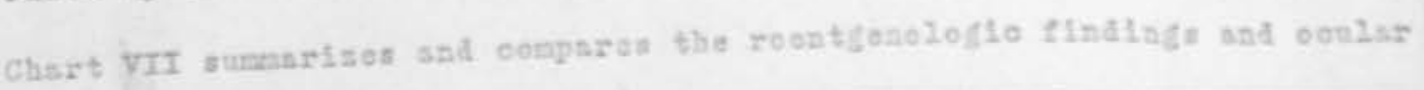




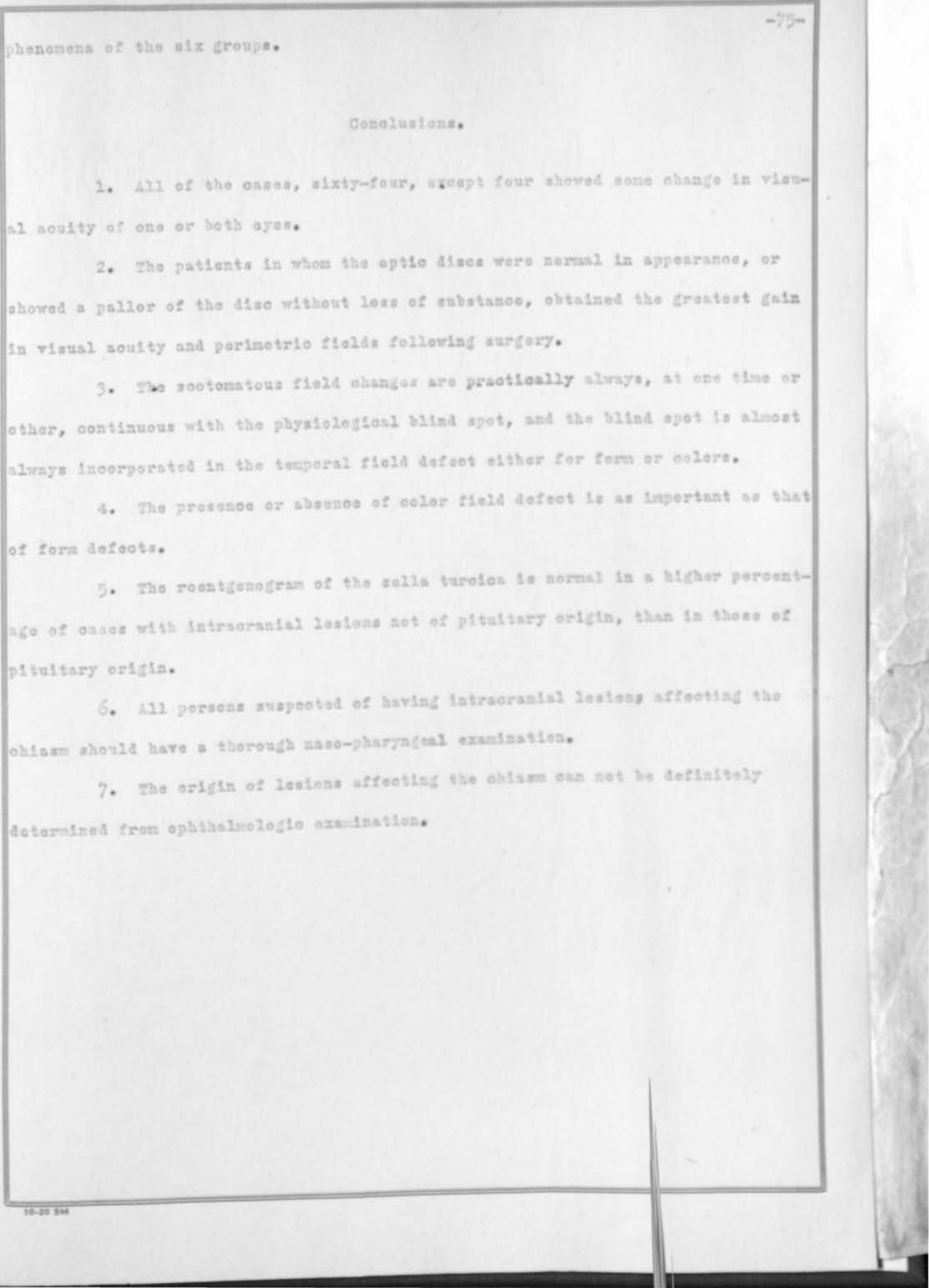


- Exposure of the pltuftary tumars utth thelr relotions to the optlo nerve and aomisare produoling the different types of fleld obanges.

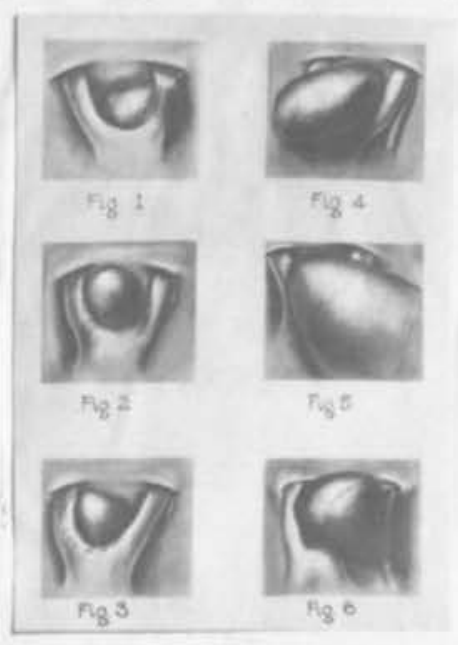

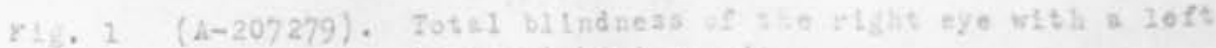

temporti Hentaliopalk.

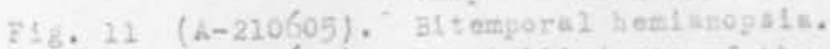

F18. III $(h-207693)$. Fotal b11ndness of the left oye w1th tomporki hemlanopsid of the right eye.

F. IV. IV $(k-219216)$. Tutsl bifpdress 1 e,ft eye with temporal

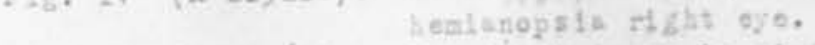

zig.V $(k-45560)$. Totul biladness tn olght eye with temporsi

Themianopsis lest oye.

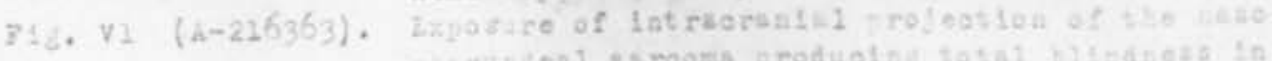

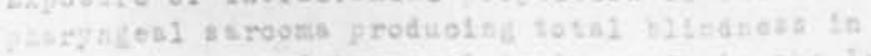

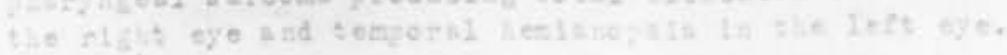

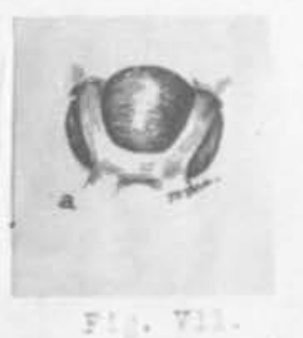

$(1-250408)$ Baten ont2 Lecthaoratil.

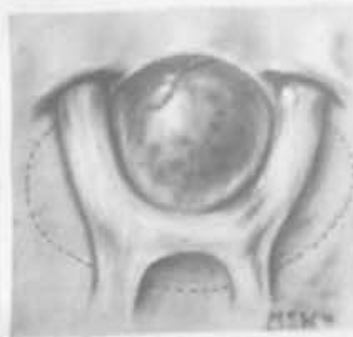

Fis. 1 .

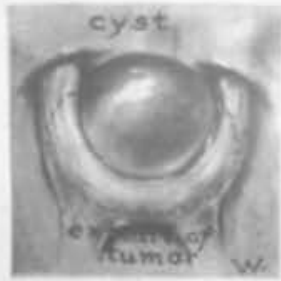

FL. T. Y:22.

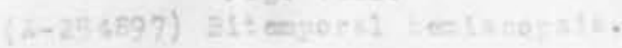

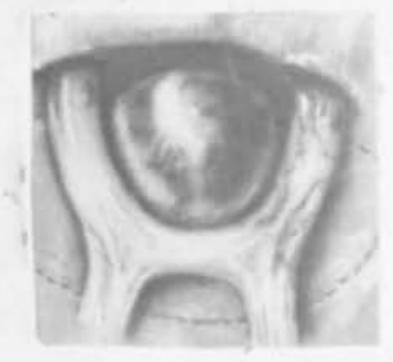

21.1. X.

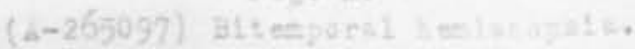



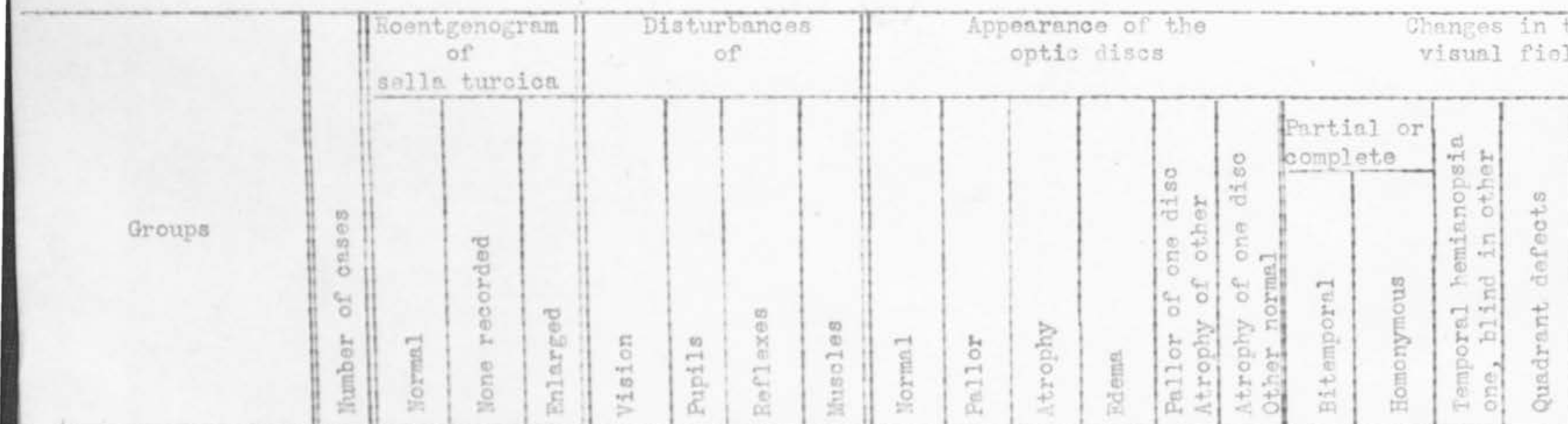

Group 1

Pituitary tumors

without, Elandu-

lar disturbanoes Group 2

Pituitery tumors With noromegaly.

\section{Group 3}

Pituitary tumora with diabetes insipidus

Tot?

Groups 1, 2 and 3 . 46 Group 4

Intraoraniel

Iesions not of

pituitary oricin

Group

Nesopharyngen 1

tumors

Group 6

Lues

Total 
1. Benodiot, W. L.: "Zariy Diagnogis of Pitultary tumor w1th Ooulax Phonomona", Amer. Jour. Ophth., 1920, 111, 571-584.

2. Dogatach: "Boltras sur Lot10log10 der b1tomporalon Hemianopalo mit begonderoff

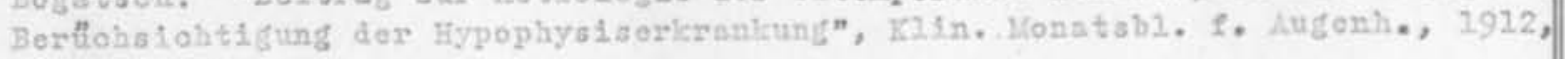
$11,313-325$.

3. Crentzleldt: "Iin Beitras sur nomalon und psthologlsohon fintomie der Hypophysis oorobri dos Konsohen", Mltt. s. d. Mamb. Stastakramicenanat., 1909, $x \leqslant 11,273-294$.

4. Gughing: "The Pituitary Body and ita Diaorders," Lippinoott, Phila, 1912.

5. Idom: "Goroerning Diabetes Irolpidus and Polyurlsa of Hypophysenl Origin", Boston Lod. snd Surg. Jour., 1913, olxvili, 901-910.

6. Idem: "The Porinatwio Deviations sooompanying Pltultary Lesions", Mod. Reon, $1913,1 \times x \times 17,134$.

7. Cushing, Harvey and Heuer, Georgo J.: "Distortiona of the Viaus? riolds in Cagos of Brain Tumor", Statistion Studfos (Firat Paper). Dull. Joling Hopleing Hosp., 1911, xxi1, 190-195.

8. Iam: "Distortions of the Visus pleldn in Cases of Brsin Mumor", (Second Papor). "Dysolromatopeia in Relation to Stages of Choked Diao", Jour. Im. Med. Assn., 1911, 1vi1, 200-208.

9. Cushing, Harvoy and Walker, Clifford B.: "Diatortion of the Viasul riolda in Ganag of Brsin Tunor. (Mird Papor). Blnassi Homianogola", Aroh. Ophth., $1912, x 11,559-598$.

10. Idem: Diatortions of the Visus piolds in Casea of Brakn Funor (Zourth

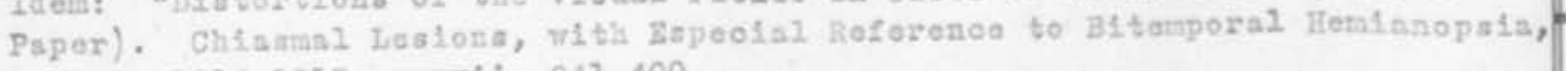
Brain", 1914-1915, xxxv11, 341-400.

11. Cusing: Distortions of the Viausl rielda in Casad of Brain Funor (Sixth

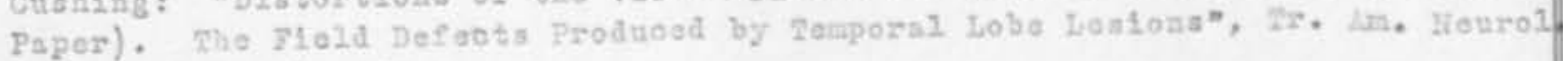
Assm., 1921, 374-423.

12. Duffy, W. C.: "Hypoplysenl Duot Fumorn", Inn. Surg., 1920, 2xx11, 537; 725.

13. Erdhein, J.: "Ueber Hypophysengangefouohrulate und Hirnoholesteatome."

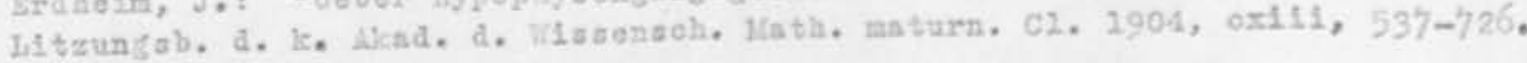

14. Yarnel, . B.: "An extrs-arobral tunor in tho region of the hypoplyyala", Jour. Herv. and lont. Dis., 1911, xaxv11i, 240.

25. Fuohs: "Whe rield of Vision in Tabetio Atrophy of the Optio Diso", Lroh. Ophth., 1921, x1, 469.

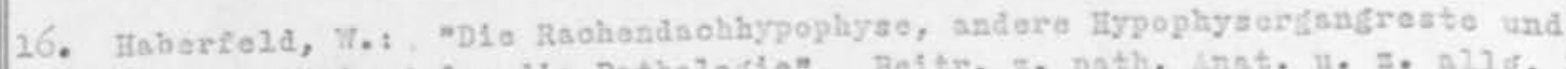
deron Bedeutung fur die Psthologio", Beitr. s. path. Lnat. u. Z, Alig. Path. $1909, x 171,133-232$.

17. Hirsoh: "Die oporstive Bohandiung ron Hypophysintumoren taoh ondonasalen Kothoden", Areh. 2. Laryngol. u. Rhinol., 1911-1912, xxv-xxv1, 529-686. 
28. Jookson: "Pitultary tumors of craniopharyngesl duct", Jour. Ma. Mad. Aagn., $2926,13 \mathrm{xv}$, $1082-1.084$.

19. Josofson, A.: "GoaichtsRoldatorungen bel den Hypoplysistumoron, mit besonaloz er. Ruolesioht au? dis bitemportile Fomianopste", Elin. Monatsbl. 1. Augonh. $2915,1 v, 636-640$.

20. Idem: "Studfar ofver akromeg311 och hypofystumorer", Stocleholm, 1903, Isaso Maraus.

21. Kumme11, R.: "Zur Kenntris dor Gesohvulste der Hypophysongegend." ünohen. mea. Wolinsclir., 1911, Iv111, 1293-1298.

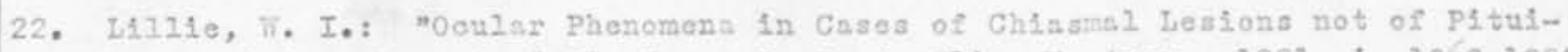
tary ONigin. Report of S1x Cases." Surg. C11n. 1t. Mner., 1921, 1, 1363-1380.

23. Irew, G. B.: "Syndrome of Malignant Tumors of the Irasopharynx." A Report of Serenty-aine csase. Jour. As. Ned. Asan., 1922, 2xxix, 10.

24. Peter, iuther C.: "Prinoiples and Prsotice of Perinetry," Les \& Febifer, Phila. and 1. Y., 1916.

25. Römo: "Uebor don Fasorvorlsue un chissan boteuohtat duroh Iind fo Gostohtsfeldustersuohungen." Klin. Monatsbl. 2. Kuganh., 1920, 11, 455.

26. de Sohvelnitz, G. I.: "Concerning the ooular symptoms in the eubjoct of hypophysesl aisesse with goquired syplilis; with illuatrative ossea." Aroh. Ophti., 1921, 1, 203-216.

27. de Sohreinltz and Holloway: "A olinicsi oomunioation on oertain visusl field defeots in hypophysis disense vith spocial peforenos to gootomas." Jour. An. Ued. Assn., 2922, 11x, 2041.

28. Stahli, J.: "Concerning oxtra-ooulax nusole paralysis aa inftial symptoms of malignant nasopharyngeal tumora." Kin. Jozstabl. f. Augenh., 2920, 2xv, 888-891.

29. Traquair, H. H.: "Contribution of the study of bitomporal hemianopsia." 3aliburgh Med. Jour., 2913, xi, 197-212.

30. Idem: "The euantitative Jethod of Parimotry."Ophth. Rev., 1914, xxx111, 65-33.

31. Ilem: "Bitemporal hemianopais; the later atages and the speolsi fostures of sootoms." Brit. Jour. Ophth., 1917, 1, 216; 281; 337.

32. Wnlicer, C. B.: "A contribution to the atuay of bitemporsi hemisnopsis with now instruments and methods for deteoting slifht ohsnges." Aroh. Ophth.,1915, ziliv, 369-402.

33. Idem: "Color Interlsoing and Porimotry." Ir. Am. Ophth. Soo., 1926, xir,684.

34. Walier, C. B.; and Cuahing, H.: "Studios of Optio Nerro Atrophy in Assoolstion vith Chiasmal Lesions." Aroh. Ophth., 1916, ziv, 107-437.

35. Walker, C. B.: "Quantitative Porlmetry; Praotion Devioes snd Errors", Aroh. Ophth. 1917, xivi, 537-561. 
36. Walicer, C. B. and Cuahins, H.: "Diatortiona of the Viausl Fielda in Cades of Brsin Tumor. (Jifth Psper) Chisanal Lealosi, rith oapeoisl referenoe to Homonymous Heminopsis vith Eypophyseal Tumor." Aroh. Ophth. 1918, xlv11, $119-145$.

37. Weisenburb, F. H.: mumors of the 3rd Vont. with the establishment of a

* Syuptom-Complex", Brein, 1910, xxxi1, 236.

38. Nilbrsnd and Skenger: "Die Meurologie des Augos." vi, Noisbsden 1915.

39. Woltmon, H. W.: Micalignant Tumors of the Hasopharyzx jith Involvomont of the 2Tervous System", Aroh. Iieurol. sud Payohiat., Acoepted for Publiontion, 1922. 